\author{
UNIVERSIDADE DE SÃO PAULO \\ ESCOLA DE COMUNICAÇÕES E ARTES \\ DEPARTAMENTO DE BIBLIOTECONOMIA E DOCUMENTAÇÃO
}

CELLY DE BRITO LIMA

\title{
O BIBLIOTECÁRIO COMO MEDIADOR CULTURAL: CONCEPÇÕES E DESAFIOS À SUA FORMAÇÃO
}




\section{O BIBLIOTECÁRIO COMO MEDIADOR CULTURAL: CONCEPÇÕES E DESAFIOS À SUA FORMAÇÃO}

Tese submetida ao Programa de PósGraduação em Ciência da Informação da Universidade São Paulo - USP, como requisito parcial para a obtenção do título de Doutor em Ciência da Informação.

Área de Concentração: Cultura e informação

Orientador: Prof. Dr. Edmir Perrotti 
Autorizo a reprodução e a divulgação total ou parcial deste trabalho, por qualquer meio convencional ou eletrônico, para fins de estudo e pesquisa, desde que citada a fonte.

\section{Catalogação da Publicação}

Lima, Celly de Brito

O bibliotecário como mediador cultural: concepções e desafios à sua formação / Celly de Brito Lima; orientação Prof. Dr. Edmir Perrotti. São Paulo: s.n., 2016.

$182 f ;$ il.

Inclui anexos

Tese (Doutorado) -- Universidade de São Paulo, 2016.

1. Ciência da Informação 2. Mediação cultural 3. Apropriação cultural 4. Formação do bibliotecário. I. Título. II. Perrotti, Edmir. III. Universidade de São Paulo, Escola de Comunicações e Artes.

CDD 020

Ficha catalográfica: Bibliotecária Carmem Lúcia Batista, CRB/8 - 6673 
LIMA, Celly de Brito

O bibliotecário como mediador cultural: concepções e desafios à sua formação

Tese apresentada ao Curso de PósGraduação em Ciência da Informação, da Escola de Comunicações e Artes da Universidade de São Paulo, como exigência parcial para a obtenção do título de Doutor em Ciência da Informação.

Aprovado em: ___

\section{Banca Examinadora}

Prof. Dr.: Edmir Perrotti

Julgamento:

Prof. Dr.:

Julgamento:

Prof. Dr.:

Julgamento:

Prof. Dr.: Instituição:

Julgamento:

Prof. Dr.:

Instituição:
Assinatura:

Julgamento:

Instituição:
Assinatura:

Assinatura:

Instituição:

Assinatura:

Instituição:

Assinatura:

Assinatura:

Instituição: ECA/USP 
A quem devo o querer e o realizar, dedico. 


\section{AGRADECIMENTOS}

Ao Prof. Edmir Perrotti pela confiança depositada em mim, pelo compartilhamento de ideias, pela compreensão, pela paciência e pela generosidade.

Aos professores Oswaldo Almeida Júnior e Fernando Modesto pelas trocas, observações e sugestões feitas no exame de qualificação.

Aos participantes do Colaboratório de Infoeducação pelas trocas e contribuições - Profa. Ivete Pieruccini, Simone, Amanda, Marcos, Lilian especialmente a Carmem Lúcia pela revisão do trabalho.

Aos queridos colegas e amigos da UFPE pelo apoio e torcida. Ao Balaio cheio de companheirismo de André, Hélio, Májory, Sandra e, especialmente, de Vildeane. Anseio retribuir com trabalho e dedicação para o alcance dos sonhos e planos em comum.

Aos professores e pesquisadores Marcos Galindo e Leilah Bufrem por serem inspiradores de solidariedade, generosidade, afetividade, doçura e engajamento.

Ao Flávio Luiz, meu marido, pelo suporte, pela preocupação, pela paciência, pela generosidade e pelo carinho.

Aos meus filhos Victor Luiz e Pierre Luiz pelo esforço de compreensão e espera.

À minha mãe Ana Rita e irmã-filha Lizzi também pelo suporte, pela compreensão e pela generosidade. Às queridas Cecile e Suia, pelo apoio e amizade.

A todas as cunhadas e aos cunhados que são como irmãos. À minha cunhada, que além de amiga e irmã é um anjo, Sandra Regina.

Aos meus tios, tias, primos e primas, pela torcida e carinho.

Ao meu amado Emanuel que sempre esteve comigo. 
Vou me encontrar, longe do meu lugar [...] Abrir o peito a força, numa procura. Fugir às armadilhas da mata escura 
LIMA, C. B. O bibliotecário como mediador cultural: concepções e desafios à sua formação. 2016. 182f. Tese (Doutorado em Ciência da Informação) - Escola de Comunicações e Artes, Universidade de São Paulo, São Paulo, 2016.

\section{RESUMO}

Este trabalho interroga a formação do bibliotecário como um mediador cultural, sujeito comprometido com processos de apropriação e de protagonismo cultural no país. A pesquisa parte da hipótese de que a mediação cultural, intrínseca à profissão de bibliotecário, é tratada de forma insuficiente e confusa em normas, diretrizes e orientações para a sua formação. Desenvolve pesquisa bibliográfica e documental para compreender e aprofundar questões em torno dos conceitos estudados. Identifica e analisa documentos orientadores que manifestam representações do profissional bibliotecário - manifestos da International Federation of Library Associations and Institutions e Organização das Nações Unidas para a Educação, a Ciência e a Cultura, além da lei brasileira que regulamenta a profissão de bibliotecário e de diretrizes do Ministério da Educação. Também desenvolve pesquisa documental em propostas brasileiras e francesas de cursos de mediação cultural - graduação e pós-graduação - no sentido de embasar a ideia do "bibliotecário mediador cultural", já que as propostas permitem inferir descrições de mediador cultural. Percebe que nas normas, diretrizes e nos documentos orientadores o bibliotecário não é colocado de forma clara como um mediador cultural, tampouco como negociador cultural, mas como um educador e difusor de cultura, que oferta serviços direcionados à assimilação e ao consumo cultural, deixando de responder à demanda da apropriação e protagonismo cultural. Considera que o desafio que precede todos os outros, para a formação do bibliotecário como mediador cultural, é o de refletir, discutir, teorizar e explicitar os conceitos de formação, superando a visão dualista (tecnicismo $\mathrm{x}$ humanismo, técnica $\mathrm{x}$ prática, fazer $\mathrm{x}$ pensar...) que vem orientando historicamente a Ciência da Informação e a Biblioteconomia.

Palavras-chave: Mediação cultural; Mediador cultural; Apropriação cultural; Formação do bibliotecário. 
LIMA, C. B. The librarian as a cultural mediator. concepts and challenges to their training. 2016. 182f. Thesis (Doctorate in Information Science) - Escola de Comunicações e Artes, Universidade de São Paulo, São Paulo, 2016.

\begin{abstract}
This work interrogates about the formation of a librarian as a cultural mediator, a person committed to processes of appropriation and cultural protagonist in the country. The research starts from the hypothesis that cultural mediation, intrinsics to the occupation of librarian is treated improperly and confusingly in standards and guidelines for their training. It carries out bibliographical and documentation research to understand and deepen issues around the concepts studied. It identifies and analyzes prescriptive documents showing representations of professional librarian manifest of the International Federation of Library Associations and Institutions and Unesco, as well as Brazilian law that regulates the occupation of librarian and guidelines Ministry of Education. It also develops documentary research in Brazilian and French proposals of cultural mediation courses - graduate and postgraduate studies -in order to support the idea of "Librarian cultural mediator", since the proposals allow us to infer descriptions of cultural mediator. It realizes that the standards, guidelines and policy documents librarian is not placed clearly as a cultural mediator, neither as a negotiator, but as an educator and diffuser of culture, that offer services aimed at assimilation and cultural consumption, failing to respond to the demand of appropriation and cultural protagonism. It considers that the challenge that precedes all others, for the formation of the librarian as a cultural mediator, is to reflect, discuss, theorize and explain the concept of formation, surpassing the dualistic view (technicality $\mathrm{x}$ humanism, technical $\mathrm{x}$ practice, do $\mathrm{x}$ think...) which has historically guiding the Information Science and the Librarianship.
\end{abstract}

Keywords: Cultural mediation; Cultural mediator; Cultural appropriation; Formation librarian. 


\section{LISTA DE FIGURAS}

Figura 1: De que serve e o que pretende a biblioteca? ..................................24

Figura 2: Protagonistas participam da vida cultural afirmativamente ....................38

Figura 3: Conhecer o conhecimento, indagar para se apropriar ........................48

Figura 4: Mediação para o controle ou para apropriação e protagonismo cultural?.53

Figura 5: Bibliotecárias do final do século XIX ...........................................113

Figura 6: Humanismo e técnicas para um público............................................113

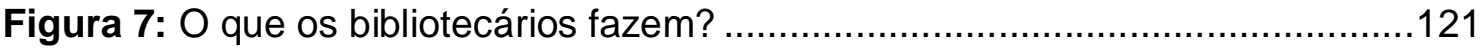

Figura 8: Tecnologias e suportes definem uma "evolução" do bibliotecário? .........124 


\section{LISTA DE QUADROS}

Quadro 1: Normas, diretrizes e orientações ........................................... 80

Quadro 2: Propostas de cursos em mediação cultural...................................100 


\section{LISTA DE SIGLAS E ABREVIATURAS}

ABEBD Associação Brasileira de Ensino de Biblioteconomia e Documentação

ABECIN Associação Brasileira de Educação em Ciência da Informação

CAFB Certificat d'Aptitude aux Fonctions de Bibliothécaire

CBBD Congresso Brasileiro de Biblioteconomia e Documentação

CBBD Congresso Brasileiro de Biblioteconomia, Documentação e Ciência da Informação

CBO Classificação Brasileira de Ocupações

Cl Ciência da Informação

CMSI Cúpula Mundial da Sociedade da Informação

DASP Departamento Administrativo do Serviço Público

DSB Diploma Superior de Bibliotecários

DTB Diploma Técnico de Bibliotecário

ENSB École Nationale Supérieure des Bibliothèques

FID International Federation for Information and Documentation

IASL International Association of School Librarianship

IBBD Instituto Brasileiro de Bibliografia e Documentação

IES Instituições de Ensino Superior

IFAP Conselho Intergovernamental do Programa de Informação para Todos

IFLA International Federation of Library Associations and Institutions

IIA Information Industry Associaton

MEC Ministério da Educação

ONU Organização das Nações Unidas

PGI General Information Programme

UEMG Universidade Estadual de Minas Gerais

UFPE Universidade Federal de Pernambuco

Unesco Organização das Nações Unidas para a Educação, a Ciência e a Cultura

UNILA Universidade da Integração Latino-americana 


\section{SUMÁRIO}

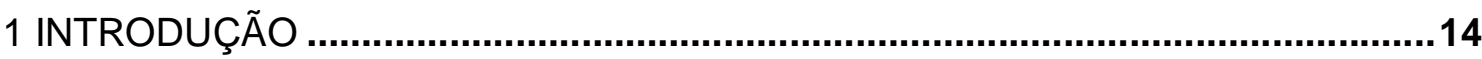

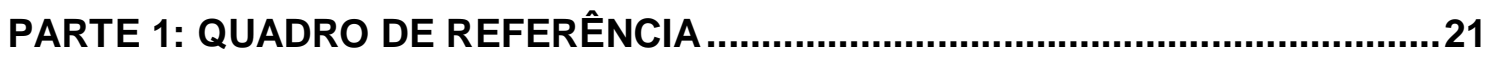

2 BIBLIOTECONOMIA E CIÊNCIA DA INFORMAÇÃO: a centralização do fluxo.....21

3 MEDIAÇÃO E MEDIADOR CULTURAL EM QUESTÃO …...................................34

4 APROPRIAÇÃO CULTURAL .........................................................................44

5 INTERCULTURALIDADE, ENTRECULTURALIDADE E NEGOCIAÇÃO

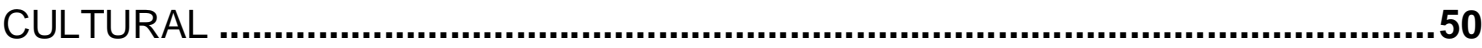

6 FORMAÇÃO EM BIBLIOTECONOMIA NO BRASIL: "humanismo" x "tecnicismo" 57

7 FORMAÇÃO EM BIBLIOTECONOMIA NA FRANÇA : o "erro" epistemológico ......67

PARTE 2: CAMINHO METODOLÓGICO .............................................................75



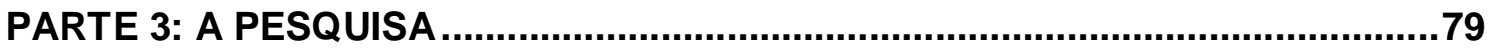

9 O BIBLIOTECÁRIO COMO MEDIADOR CULTURAL: pautas para a formação ....79

9.1 Normas, diretrizes e orientações para a biblioteca e para a formação do

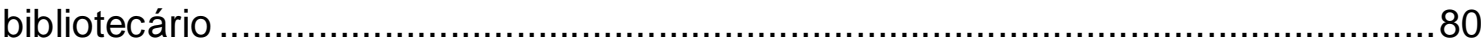

9.2 Propostas de formação em mediação cultural, na França e no Brasil.................100

10 FORMAÇÃO DO BIBLIOTECÁRIO COMO MEDIADOR CULTURAL: desafios 111

10.1 Humanismo ou técnica: falso dualismo …………....................................114

10.2 Bibliotecário: mediador cultural para quê? ................................................121

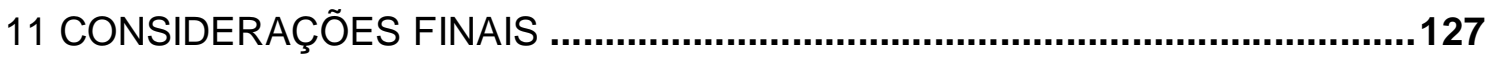

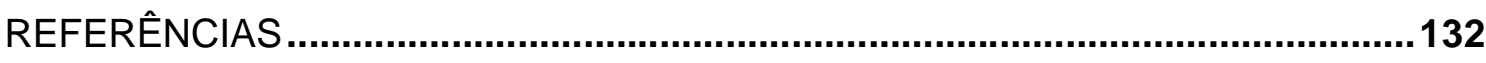

ANEXOS

ANEXO A: LEGISLAÇÃO QUE REGULAM A PROFISSÃO DE BIBLIOTECÁRIO.139 ANEXO B: DIRETRIZES CURRICULARES PARA OS CURSOS DE

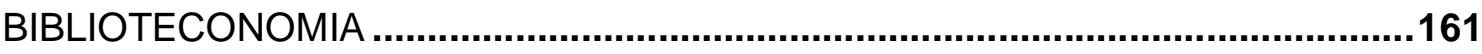

ANEXO C: HOMOLOGAÇÃO DAS DIRETRIZES CURRICULARES PARA OS CURSOS DE BIBLIOTECONOMIA ....................................................................166

ANEXO D: IFLA/UNESCO PUBLIC LIBRARY MANIFESTO (1994) .......................171

ANEXO E: MANIFESTO IFLA/UNESCO PARA BIBLIOTECA ESCOLAR ...............174

ANEXO F: MANIFESTO IFLA/UNESCO POR LA BIBLIOTECA MULTICULTURAL178 ANEXO G: CURRÍCULOS E PROPOSTAS CURRICULARES DE BIBLIOTECONOMIA NO BRASIL (1911-1982)......................................................182 


\section{INTRODUÇÃO}

Antes mesmo do ingresso no curso de Biblioteconomia, da Universidade Federal de Pernambuco, em 1999, era guiada pelo desejo de uma escolha de atuação profissional que, além de oferecer satisfação pessoal, pudesse contribuir para afirmar o direito ao conhecimento. Entendia isso como valor a ser garantido a todos, na sociedade brasileira. Acreditava e defendia o direito fundamental de todo ser humano de fruir as artes, a ciência, a vida cultural.

Todavia, meu interesse não se reduzia simplesmente ao desejo de inclusão como forma de adaptação dos sujeitos ao universo da cultura e do conhecimento hegemônico dito "oficial". Acreditava - e continuo acreditando - que o direito fundamental de todo ser humano ao conhecimento implica o reconhecimento de um processo de mão dupla entre a cultura e os sujeitos, tomados não como meros receptáculos de signos a serem neles depositados (FREIRE, 2005), "outorgados" (ESCARPIT, 1969), mas como protagonistas portadores de saberes que atuam e não podem ser silenciados nos processos de conhecimento e de cultura.

Minha proximidade com o Recife talvez tivesse definido uma orientação que, mais tarde, eu procuraria compreender e nomear, e que, necessariamente, remetia a posições freireanas de luta contra a "cultura do silêncio". Sim, pois a crença no direito ao conhecimento vinha para mim associada, sempre, a um diálogo; reconhecia tanto o valor inestimável das artes, da ciência, dos "saberes tradicionais", como o dos modos de ver, de sentir, de pensar de grupos e de cada um. Para retomar um termo de Freire ("educação bancária") de modo novo, não me interessava a "difusão bancária" de conhecimento e de cultura, mas outros modos de relação, de participação na cultura que, se não sabia nomear adequadamente, tinha certeza, era caminho a ser buscado e seguido em minha formação.

Tendo cursado o ensino médio em meio a uma vontade de engajamento social, de envolvimento com o movimento estudantil secundarista, ingressei, em seguida, num curso técnico de Rádio e TV. Pensava, na época, que talvez devesse seguir a carreira de jornalista, podendo assim desenvolver um trabalho voltado à informação, à conscientização do público e a favor do empoderamento da cultura. No entanto, pareceu-me, depois, que a Biblioteconomia poderia oferecer, além de possibilidades de satisfação e de realizações pessoais, os subsídios necessários à minha atuação como profissional comprometida e socialmente responsável. 
Logo após o ingresso no curso, comecei, porém, a questionar se tinha feito realmente a escolha certa. Durante os primeiros semestres, vivi a experiência de trabalhar numa empresa de internet que tentava, por meio de um portal corporativo uma inovação à época -, se estabelecer no mercado brasileiro. Ao mesmo tempo, cursava disciplinas das áreas ditas "humanas" e de formação geral, como Estudos sócio-político-econômicos, Introdução à comunicação, Literatura luso-brasileira e Literatura infanto-juvenil. A qualidade dos professores, dos enfoques dados por eles às disciplinas que ministravam - em especial a de Literatura infanto-juvenil -, a seleção dos conteúdos colocados em discussão, tudo isso aliado à experiência de trabalho ligada ao mundo digital que então emergia com força, me levaram a refletir sobre o letramento digital e cultural, a dita "era digital" e, particularmente, a exclusão social e digital, suas tramas e as implicações nos direitos dos cidadãos.

Como não podia deixar de ser, tais reflexões tiveram como direção a interrogação sobre o lugar do bibliotecário enquanto ator privilegiado desse cenário, a função social da profissão, os caminhos oferecidos pelo curso que eu escolhera. Estaria este, de fato, atuando a favor do acesso ao conhecimento, à cultura? Estaria ele conectado com as novas realidades das tecnologias digitais? Com a influência destas no modo de vida das pessoas? Estaria o bibliotecário, com a formação que Ihe era oferecida, em condições de dar conta de uma realidade profundamente complexa e desigual, social, política, econômica e cultural? Estaria preparado para lidar com sujeitos pertencentes a universos múltiplos, dos mais aos menos alfabetizados, e de tantos analfabetos digitais? Estariam os cursos voltados à formação de profissionais capazes de atuar de forma efetiva em uma cultura cuja característica é a midiatização crescente (PERAYA, 2002)? Como estaria sendo considerada na formação do bibliotecário a sobreposição de informação, a falta de acesso a informações relevantes, o bombardeio de informações irrelevantes e sufocantes (PERROTTI, 2008), a velocidade dos fluxos informacionais? O consumo e o consumismo dos signos promovidos a valor identitário estariam na agenda de formação dos "profissionais da informação"? De que forma?

Enfim, se os semestres iniciais do curso me abriam horizontes com suas disciplinas de cultura geral, de outro lado, o olhar prospectivo me colocava dúvidas, ao observar a trajetória acadêmica que, especialmente, o núcleo do que era tido como "específico" do curso de Biblioteconomia me propunha. Para mim, naquele momento, mesmo sem talvez saber nomear devidamente a questão, existia uma 
fragmentação entre as questões colocadas pelas áreas de "estudos gerais" e aquelas dos "estudos específicos". E tal fragmentação, importante dizer, não se resumia à falta de articulação didático-pedagógica necessária entre as áreas. Nesse aspecto, era possível notar até alguns esforços de articulação por parte do curso. Mais do que isso, porém, tratava-se de uma fragmentação epistemológica: eu observava uma fratura entre as "ferramentas" propostas pelas disciplinas de formação técnica especializada e minhas preocupações com o papel social do bibliotecário e que me levaram à escolha do curso universitário. Além disso, notava, também, que o domínio e a utilização de tais "ferramentas" era o que, diante do senso comum, constituía a base da identidade social do bibliotecário.

Ora, meu interesse pelo letramento digital e literário me levou a participar de projetos de extensão universitária nesta área, proporcionando-me horizontes de atuação distintos dos simplesmente técnico-especializados. Eles incluíam funções técnicas e especializadas, sem dúvidas, mas não se esgotavam em tais dimensões, iam muito além, ou seja, ao encontro de minhas aspirações de profissional compromissado com a participação afirmativa dos sujeitos na cultura e nos processos de construção de conhecimentos.

As possibilidades vislumbradas pelas experiências pelas quais eu passava mostravam-me, porém, que se havia perspectivas, era preciso, por outro lado, construir bases teóricas que poderiam dar sustentação a essa atuação que ultrapassava os limites técnico-especializados e que ia ao encontro de meus propósitos ao escolher o curso de Biblioteconomia. Que elementos da formação acadêmica dariam esse suporte? Que outros elementos buscar? Onde? Na própria universidade? Fora dela?

Tais inquietações, se não conseguiram produzir respostas satisfatórias e imediatas, permitiram a percepção de que não só precisava estudar, construir bases conceituais e metodológicas consistentes para dar conta de minhas preocupações, como permitiram explicitar também que eu gostaria de pesquisar, de teorizar e, além disso, se possível, atuar na formação em Biblioteconomia, tendo em vista, refletir e contribuir para a superação de dificuldades que atingem diretamente a todos os que, como eu, se preocupam com o papel do bibliotecário na sociedade e na cultura. Minha recusa não era, portanto, um ato centrado unicamente em meu próprio futuro profissional. Ela incluía, sobretudo, uma área de atuação - a Biblioteconomia - a preocupação com outros profissionais que, como eu, desejavam contribuir para a 
vida pública, para o avanço social, para a participação afirmativa nos circuitos de produção de conhecimento e cultura de enormes segmentos da população brasileira deles excluídos. Estaria em causa a superação da "ordem informacional monológica" (PIERUCCINI, 2004) reinante no país de longa data, ou seja, para a construção social de "ordem cultural dialógica".

O primeiro passo nessa direção, após concluir a graduação em Biblioteconomia, foi o ingresso no mestrado em Ciência da Informação, na Universidade Federal da Paraíba, na área de concentração em Informação, Conhecimento e Sociedade, e na linha de pesquisa Memória, Organização, Acesso e Uso da Informação. Cursando ainda as disciplinas do mestrado e com interesse no tema da democratização e acesso à informação e à cultura, bem como suas aproximações com os fazeres e os saberes da Biblioteconomia, me deparei com as questões de identidade e etnia de sujeitos da informação e da cultura na era digital o que passou a ser o foco de minhas pesquisas.

A proposta foi então verificar como se situam as identidades afrodescendentes em tempos de cibercultura, na era digital, na dita "sociedade da informação", a partir da questão do acesso e da democratização da informação, tecia uma discussão baseada em referências e nos dados coletados sobre as condições de imersão dadas aos afrodescendentes na cibercultura e quais as conexões desse panorama sociocultural, e implicações do racismo, na construção de suas identidades.

Nesse trabalho foram abordados textos sobre temas como "era digital", "responsabilidade social da Ciência da Informação", "construção de identidades na pós-modernidade", "inclusão social/digital no Brasil", "racismo no Brasil" e realizadas reflexões sobre as falas dos sujeitos entrevistados e as teorias requisitadas mediante seus depoimentos.

Todavia, apenas com os dados da pesquisa de mestrado, não era possível diagnosticar a "afrodescendência na cibercultura", mas sim ratificar o alcance/persistência da desigualdade social frente às "novas formas" ou evolução da cultura, interação e no acesso à informação e a cultura para afrodescendentes. Concluímos, com a dissertação, que, no caso dos usuários da Praça da Informação da Biblioteca Pública de Pernambuco (locus da pesquisa), o fato de terem acesso limitado (em vários sentidos) à internet e seus fluxos de informação, torna a imersão na cibercultura incompleta, com prejuízos à capacidade de participação social e ao 
exercício da cidadania. E, a partir de então, meu interesse seria ampliado para as questões de mediação, apropriação e protagonismo cultural.

Ao término do mestrado ingressei como professora substituta e, em seguida, como assistente, na Universidade Federal de Pernambuco. Ministrando disciplinas como "Informação e sociedade", "Ação cultural em bibliotecas", no curso de Biblioteconomia, e "Direito da Informação", no curso de Gestão da Informação, senti a necessidade de retomar o foco nas questões de formação e função sociocultural do "profissional da informação" no contexto das dinâmicas culturais.

$\mathrm{Na}$ direção de problematizar as perspectivas do profissional Bibliotecário e sua formação, sob o entendimento do Bibliotecário como mediador cultural, considerei a relação dos temas da mediação, da apropriação e do protagonismo cultural na discussão, culminando no esboço de um projeto de doutorado. Paralelamente, surgiu também a oportunidade, para o Departamento de Ciência da Informação, da Universidade Federal de Pernambuco (UFPE), no qual sou lotada, de implantar Curso de Especialização em Mediação Cultural, o que me instigou ainda mais a me debruçar sobre as questões epistemológicas que envolvem os conceitos e a formação do bibliotecário e seu papel de mediador cultural, objeto central desta tese.

Assim, observando como discente, depois docente e pesquisadora comprometida com a criação científica indispensável à construção de uma "ordem informacional dialógica" na contemporaneidade, chegamos à questão abordada nesta tese. Segundo nossa compreensão, a mediação cultural, entendida como categoria central da profissão de bibliotecário, dos processos de apropriação cultural, é tratada de forma insuficiente e confusa, tomando-se por base normas, diretrizes, orientações, concepções e caminhos percorridos pela formação de bibliotecários no Brasil. Tal fato é preocupante, já que a atuação do bibliotecário implica necessariamente processos de mediação de informação e ele necessita, portanto, de referências teórico-metodológicas sólidas a respeito. As ferramentas técnicas especializadas da profissão, por exemplo, sejam as referentes à organização ou a gestão dos documentos e das instituições bibliotecárias, ou as referentes às relações entre os acervos culturais e os públicos - "mediações explícitas" (ALMEIDA JÚNIOR, 2009) - inscrevem-se, assim, obrigatoriamente, em paradigmas culturais, em lógicas que precisam ser reconhecidas, tendo em vista necessidades de superação, tanto de condições históricas próprias das relações 
entre informação e sociedade no país, como de condições nascidas de problemáticas complexas da chamada "Era da Informação".

O objetivo geral desta tese é, pois, interrogar a formação, no país, do bibliotecário entendido como mediador cultural. Do ponto de vista dos objetivos específicos, pretende-se fornecer referências capazes de apontar perspectivas de superação de desafios para a formação do bibliotecário como mediador cultural, comprometido com processos de apropriação e de protagonismo cultural. A hipótese desta pesquisa é a de que a mediação cultural, intrínseca à profissão de bibliotecário, é tratada de forma insuficiente e confusa em normas, diretrizes e orientações para a sua formação.

A organização deste trabalho é descrita a seguir:

$\mathrm{Na}$ introdução, apresentamos as motivações pessoais, sociais, profissionais e acadêmicas, bem como a justificativa, os objetivos da tese e a hipótese.

No segundo capítulo, intitulado "Biblioteconomia e Ciência da Informação: a centralização do fluxo", situamos a Biblioteconomia no contexto da "explosão informacional" e apresentamos a Ciência da Informação (Cl), abordando entendimentos divergentes sobre ela como ciência moderna e como ciência pósmoderna, levantando uma discussão sobre a centralidade no fluxo e o lugar que a cultura, ou o cultural, pode ocupar nesta ciência no sentido da teorização da mediação cultural.

No terceiro capítulo, "Mediação e mediador cultural em questão" apresentamos conceitos e definições sobre a mediação cultural e, portanto, o mediador cultural.

No quarto capítulo, "Apropriação cultural”, buscamos elucidar a noção de apropriação cultural.

O quinto capítulo, "Interculturalidade, entreculturalidade e negociação cultural", foi elaborado para trabalhar tais noções no sentido de apresentar o mediador cultural como um negociador entre culturas: a da biblioteca e a de seus públicos.

No sexto capítulo, "Formação em Biblioteconomia no Brasil: 'humanismo' x 'tecnicismo'" mostramos os caminhos da formação em Biblioteconomia no Brasil no século XX, com base em estudos já realizados, para entendermos foco e delineamentos da formação nesse período, com repercussão na contemporaneidade. 
Com essa mesma intenção, no sétimo capítulo, "Formação em Biblioteconomia na França: o 'erro' epistemológico", mostramos caminhos da formação em Biblioteconomia na França, no século XX, a fim de situar com maior clareza nossa perspectiva.

No oitavo capítulo, "Acerca da metodologia", temos o percurso metodológico e o corpus da pesquisa.

No nono capítulo, "O Bibliotecário como mediador cultural: pautas para a formação", analisamos representações do profissional bibliotecário em normas, diretrizes e documentos orientadores para a formação na área de Biblioteconomia no Brasil. E, também, analisamos apresentações de propostas de cursos de mediação cultural: dois cursos de mestrado e um de graduação na França e dois cursos de especialização e um de graduação no Brasil. Com isso, pretendemos ampliar a discussão sobre a compreensão do que seja a mediação cultural, bem como os caminhos possíveis para a formação de bibliotecário como mediador cultural.

O décimo capítulo, "O Bibliotecário como mediador cultural: desafios", foi construído para sintetizar e discutir as concepções e os desafios identificados para a formação do bibliotecário como mediador cultural.

Por fim, temos as Considerações finais, seguidas das Referências utilizadas neste texto e dos Anexos. 


\section{BIBLIOTECONOMIA E CIÊNCIA DA INFORMAÇÃO: a centralização do fluxo}

Ao referir-se à "explosão informacional" do século XVI, Peter Burke (2002) chama a atenção para a problemática da informação em seus múltiplos aspectos, dentre eles, o da preservação e da recuperação do grande volume de registros. Ele afirma que a tipografia gerou a necessidade de métodos novos para 0 gerenciamento de informação e destaca a preservação da informação, bem como a seleção e a crítica de livros e autores como um dos problemas mais sérios desde então. Segundo Burke (2002, p.175):

No século $\mathrm{XVI}$ o problema era o da superfluidade [...] Livros eram uma "floresta" na qual os leitores poderiam se perder, segundo Jean Calvin [...] $O$ bibliotecário francês Adrien Baillet temia que a multiplicação de livros trouxesse consigo uma nova época de barbárie.

Por outro lado, Burke lembra que os bibliotecários se tornaram "ainda mais indispensáveis" e que a multiplicação de livros criou, imediatamente, um problema para esse grupo profissional:

[...] foi preciso compilar catálogos para grandes bibliotecas, particulares ou públicas. Baillet compilou um catálogo em 32 volumes para seu patrão, o magistrado Lamoignon, um trabalho que ajuda a explicar seu desabafo, como já mencionado, sobre o advento de uma época de barbárie.

E para mostrar que todos os problemas desse profissional tiveram soluções que geraram outros problemas e trouxeram mudanças para a organização da informação, Burke (2002, p. 177-179), discorre:

[...] A compilação desses catálogos criou o problema de como organizá-los. Por assunto ou por autor numa lista em ordem alfabética? Se por assunto, segundo o tradicional currículo das universidades ou de um modo novo e mais adequado às novas descobertas (um problema que, entre outros, preocupava Leibniz)? Também existia o problema do acesso. Como poderiam os leitores 
descobrir que livros estavam disponíveis numa determinada biblioteca? [...] bibliografias gerais foram sucedidas por outras mais específicas e fáceis de manusear [...] às vezes na forma de orientação para quem desejasse formar uma biblioteca, ajudava os leitores a fazerem sua escolha entre livros concorrentes [...] Como o aparecimento de bibliografias em meados do século $\mathrm{XVI}$, o aparecimento de resenhas cem anos mais tarde foi uma resposta a um problema que se tornara cada vez mais agudo [...] Como as bibliografias, algumas dessas revistas eram especializadas [...] Essa solução, por sua vez, gerou o problema da localização das resenhas, ou mesmo de achar as revistas, que eram publicadas em tantas cidades diversas da Europa e às vezes duravam apenas alguns anos [...] Às bibliografias logo se juntaram estantes de outros livros de referência [...] Havia também coleções de muitos volumes de textos sobre tópicos específicos - leis, tratados, crônicas, decisões de concílios da Igreja, descrições de lugares exóticos feitas por viajantes etc. [...] A comercialização do conhecimento já era visível na época de Gutenberg, como testemunham os volantes comerciais que anunciavam libri venales (livros à venda). Todavia, a comercialização deu um grande passo para a frente no século XVIII, participando do surgimento da 'sociedade de consumo' na Inglaterra, na França, na Alemanha e em outros países por volta de 1750 [...]”.

Da época mencionada por Burke à nossa época, a "explosão informacional" se alastrou em grandes proporções. Um artigo de Vannevar Bush, datado de 1945, também trata a questão, explorando-a na perspectiva da documentação, especificamente a documentação científica e tecnológica, situando-a no século XX:

Tanto esforço feito simplesmente para a manipulação e o registro das idéias. Até então, parece que estamos piores do que antes - já que podemos estender os registros enormemente; afinal, mesmo 0 atual volume de registros é difícil de ser consultado. Esse é um problema muito maior do que a simples extração de dados para a pesquisa científica e envolve todo o processo pelo qual o homem evolui a partir do conhecimento que adquire. A base do uso é a seleção e, nesse ponto, estamos certamente paralisados. (BUSH, 2007, p. 21).

O crescimento exponencial da informação em ciência e em tecnologia teria, então, tornado urgente o desenvolvimento de uma Ciência da Informação. Esta, segundo Le Coadic (2004), teria sido gestada na Biblioteconomia, por meio dos conteúdos reunidos nas bibliotecas. Tal fato não significa dizer, no entanto, que seja a Cl uma evolução da Biblioteconomia. Para esse autor, são campos distintos, um ligado à construção científica, o outro, às práticas sociais concretas com a informação e a cultura. Ambos compartilham, no entanto, um mesmo objeto social a informação -, segundo Saracevic (1996). 
Mas ao se considerar como um domínio da Ciência da Informação, a Biblioteconomia que, em seu surgimento, é voltada para os registros, os "objetos da memória", volta seu olhar para o fluxo da informação. E, por isso, notadamente, tanto a dimensão da memória quanto a dimensão social e cultural da informação tanto na Biblioteconomia como na $\mathrm{Cl}$ - passa a se redefinir, ocupando às vezes, um lugar periférico, alegando urgências da "sociedade da informação".

Na concepção de Latour (2008, p. 22 -23) a informação é como:

[...] uma relação estabelecida entre dois lugares, o primeiro, que se torna periferia, e o segundo, que se torna centro, sob a condição de que entre os dois circule um veículo que denominamos forma, mas que para insistir em seu aspecto material, eu chamo de inscrição [...].

Por fim, segundo o autor:

Verifica-se que a informação não é uma "forma" no sentido platônico do termo, e sim uma relação muito prática e muito material entre dois lugares, o primeiro dos quais negocia o que deve retirar do segundo, a fim de mantê-lo sob sua vista e agir à distância sobre ele.

Latour (2008, p. 21) pondera: "Em vez de considerar a biblioteca como uma fortaleza isolada ou como um tigre de papel, pretendo pintá-la como o nó de uma vasta rede onde circulam não os signos, não matérias, e sim matérias tornando-se signos". Mas também nos lembra que "os que se interessam pelas bibliotecas falam freqüentemente dos textos, dos livros, dos escritos, bem como de sua acumulação, de sua conservação, de sua leitura e de sua exegese.". E alerta: "Tem certamente razão, mas há um certo risco de limitar a ecologia dos lugares de saber aos signos ou à simples matéria do escrito [...]". A tirinha suscita a questão dos sentidos e da materialização da biblioteca. 
Figura 1: De que serve e o que pretende a biblioteca?
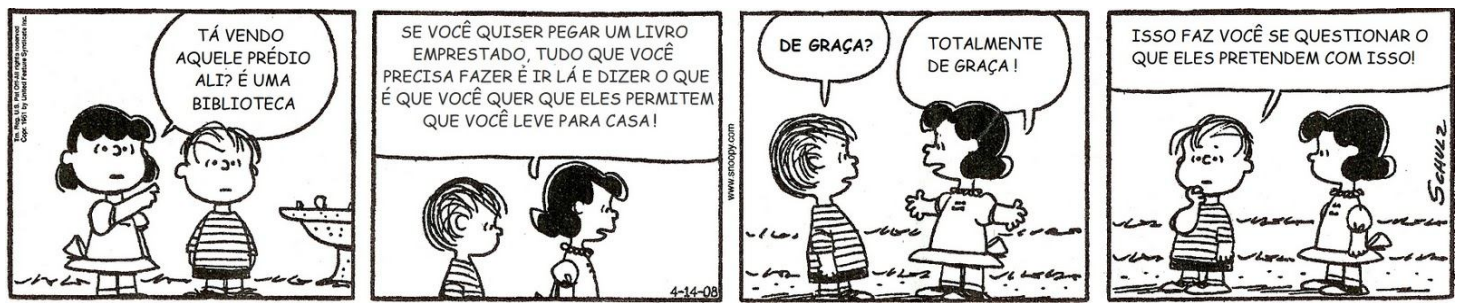

Fonte: Charges sobre livros, bibliotecas e bibliotecários ${ }^{1}$.

Latour (2008, p. 21) considerando as bibliotecas lugares de saber e de memória junto a outros dispositivos, enfatiza que

[...] a circulação desses intermediários muitas vezes desprezados fabrica não só o corpo, mas também a alma do conhecimento [...] serve de receptáculo provisório, de dispatcher, de transformador e de agulha a fluxos bem concretos que ela movimenta continuamente.

Assim, a informação medeia e é mediada: por objetos, estruturas linguísticas de pensamentos, por práticas sociais e institucionais. Shera (1977, p. 10), no artigo intitulado "Epistemologia social, semântica geral e biblioteconomia", diz que "A própria linguagem pode determinar tanto o comportamento e a conduta individuais, como grupais". Para ele:

Assim como a necessidade de informação orienta o indivíduo, assim também orienta sociedades. É a base do comportamento coletivo, tanto quanto do comportamento individual [...] o que é conhecido por cada um dos membros do grupo deve ser comunicável e comunicado. (SHERA, 1977, p. 10).

Continuando com o autor, ele diz que: "Apesar da imagem popular do bibliotecário, ele não é, ou pelo menos não deveria ser, um criado cujo único propósito é apanhar e carregar aparas bibliográficas”. (SHERA, 1977, p. 11).

Por sua vez, ao tratar da Ciência da Informação, no capítulo referente à Epistemologia e história da Ciência da Informação, Le Coadic (2004) apresenta elementos para sustentar a afirmação de que a Ciência da Informação é uma

\footnotetext{
${ }^{1}$ Disponível em: http://disseminacaodainformacao-ici.blogspot.com.br/2014/07/charges-sobre-livrosbibliotecas-e.html. Acesso em: jun. 2015.
} 
disciplina constituída de conceitos científicos e técnicos, métodos, leis, modelos, teorias e história, ou seja, aquilo que caracteriza um estatuto epistemológico indispensável à afirmação de qualquer campo de conhecimento. Os conceitos, que são as definições estáveis e idênticas para abordar um conjunto delimitado de fenômenos, segundo o autor, podem ser operacionais, como os conceitos científicos de sistema de gerenciamento de bases de dados relacionais, citação, hipertexto, obsolência, impacto e classificação. Mas, também, não operacionais, como o conceito de relevância. O autor observa ainda que vários conceitos científicos da linguagem da Ciência da Informação foram desenvolvidos em outras disciplinas, como a Sociologia e a Lógica.

Além disso, Le Coadic discorre sobre conceitos técnicos que, segundo ele, seriam menos estáveis e mais qualitativos: "Refere-se, por exemplo, à gestão e armazenamento de documentos, referência bibliográfica, tesauro, catálogo. Não se prestam à medição, mas à normalização." (LE COADIC, 2004, p. 63).

Quanto aos métodos da Ciência da Informação, Coadic refere-se aos de Análise de Documentos e Informação - como a catalogação e a indexação -, lembrando que essa ciência se vale também dos métodos elaborados em disciplinas como a Linguística, a Estatística, a Sociologia e a Psicologia, como, por exemplo, os Métodos de Reformulação (resumos e sínteses) e os Infométricos.

Le Coadic (2004) considera que a Cl é uma disciplina que busca estabelecer leis que permitam fazer previsões e análises estruturais numa linguagem formalizada, citando, dentre essas leis, as Leis bibliométricas, úteis, segundo ele, na gestão de acervo e a Lei de Bradford para as definições de políticas de aquisição.

Quanto aos modelos, o autor diz que são válidos até serem refutados. E, sendo também formas de descrever a realidade, "[...] é bem possível que vários modelos possam lidar com um mesmo conjunto de fenômenos." (LE COADIC, 2004, p. 71). E, assim, lista alguns modelos: o da Modelização dos Processos de Comunicação - modelo verbal, matemático, centrado na audiência, orientado para o receptor, orientado para os usuários, dentre outros, e da Modelização dos Processos de Recuperação da Informação - modelo booleano, vetorial, probabilístico, linguístico.

O autor, no entanto, lamenta a falta de teorias na Ciência da Informação para interpretar cientificamente e racionalmente suas leis e modelos empíricos. Segundo ele, "Em matéria de informação, a prática sempre precedeu a teoria. A teoria corre 
atrás dos fatos para compreendê-los." (LE COADIC, 2004, p. 75). Para exemplificar sua afirmação, discorre sobre algumas abordagens teóricas dos processos de comunicação como a Teoria matemática da informação, segundo a qual a informação é um conceito físico, a Teoria das mídias de massa - a transmissão da informação como comunicação de massa de uma informação-espetáculo - e a Teoria da comunicação interativa, que considera o intercâmbio de informação como resultante de uma interação em um contexto. Afirma, também, que "[...] uma teoria surge como hipótese e não como generalização de observações empíricas." (LE COADIC, 2004, p. 76).

Já sobre a história da Cl, Le Coadic (2004) diz que essa não tem sido contada com os relatos do surgimento de ideias, conceitos, métodos e teorias (como na história da Física ou da Química), mas, segundo ele, com a história, apenas descritiva, das instituições, predominantemente as das bibliotecas e das técnicas, sem serem feitas conexões com uma perspectiva disciplinar de informação e a história dos indivíduos (Otlet, Ranganathan, Bush, Bradford, Brooks, Briet, Escarpit).

Além disso, o autor observa que as histórias das instituições, das técnicas e das pessoas "[...] jamais estudaram verdadeiramente a forma como as relações sociais influenciaram, ao longo do tempo, a produção da ciência da informação [...]". (LE COADIC, 2004, p. 83). O autor está criticando, portanto, concepções que não estabelecem relações entre informação, sociedade e cultura.

De qualquer modo, fica evidente o esforço de Le Coadic em localizar a Ciência da Informação, no quadro da ciência moderna, como uma ciência que busca estabelecer leis e teorias para interpretar essas mesmas leis e os modelos empíricos inseridos em quadro histórico social.

Num contraponto a perspectiva de Le Coadic, Wersig (1993) afirma que a Ciência da Informação enquadra-se na ideia de configuração das novas ciências, as pós-modernas, caracterizadas pela ausência de um método específico e voltadas para o crescimento de estratégias para lidar com ou resolver problemas do nosso mundo, inclusive os decorrentes ou intensificados pelos resultados das ciências clássicas e das tecnologias.

Para Wersig (1993), a identificação de problemas é parte de qualquer assunto ou disciplina. Quanto aos métodos selecionados para propor a solução dos problemas, no caso da $\mathrm{Cl}$, Wersig afirma a notória prevalência dos estudos de casos e da pesquisa social qualitativa. No entanto, persiste a discussão em torno de uma 
metodologia própria à Ciência da Informação, mesmo diante de sua intrínseca interdisciplinaridade.

Wersig (1993) defende que a Ciência da Informação se configura como uma ciência pós-moderna no sentido em que estaria voltada para o desenvolvimento de estratégias de resolução de problemas. Dentre esses problemas estariam aqueles causados pelas próprias ciências clássicas no seu percurso de desenvolvimento. O autor afirma ainda que essa "nova" ciência demanda uma autodefinição do seu campo, já que sob a luz das definições de ciência que já temos estabelecidas, ela não poderia ser enxergada.

No entanto, a dificuldade para a $\mathrm{Cl}$, segundo Wersig (1993), está em consolidar um panorama do seu campo - desenvolvendo conceitos genéricos e reformulando-os ou abandonando-os de acordo com seus objetivos e no confronto com os processos da realidade. $O$ autor, portanto, trabalha a ideia do que ele denomina de "interconceitos" - conceitos apropriados por disciplinas tradicionais de forma restrita a cada uma delas e que, por isso, não são entendidos de forma transdisciplinar.

Além disso, para Wersig (1993), a proposta da Cl poderia ser a de ajudar as pessoas a usarem o conhecimento, categoria que tem um papel decisivo na vida de indivíduos, organizações e culturas. A atualidade dessa consideração se deve à observação de que para a questão do uso do conhecimento não se consegue impor uma solução, mas a proposição de estratégias para soluções. De acordo com o autor, esses conhecimentos encontram-se fragmentados nos campos científicos e na oferta da indústria cultural. Podemos inferir, portanto, que as pessoas precisam compor os fragmentos e fazer uso dessa composição para o que necessitam ou desejam, apropriando-se, assim, de conhecimentos.

Em meio a dificuldades de definição do campo científico, o que podemos afirmar é que o estudo da informação e das dinâmicas socioculturais, relacionadas à sua produção, uso, mediação e apropriação, é fundamental para a sociedade. A própria convenção de que se estabelece como Sociedade da Informação e do Conhecimento, apesar de todas as controvérsias, esclarece e respalda essa consideração.

Santos (1987) defende que a ciência deveria se ocupar do fim das coisas: "As leis da ciência moderna são um tipo de causa formal que privilegia o como funciona das coisas em detrimento de qual o agente ou qual o fim das coisas.". (SANTOS, 
1987, p. 51). Dessa forma, esse pensamento científico não se dá na direção de compreender a realidade e a natureza, mas de dominá-las e transformá-las. Pensamento esse que passou a nortear o estudo da sociedade.

No entanto, segundo esse autor, na medida em que os próprios cientistas foram desenvolvendo o interesse filosófico, no sentido de problematizar a ciência, antes restrito ao campo da sociologia da ciência, as reflexões epistemológicas passaram a incluir necessariamente as análises socioculturais. Então, agora, "a introdução dos conceitos de historicidade e de processo nos estudos das ciências naturais, proporcionam condições para um autoconhecimento - como se agora o homem e a mulher [...] se descobrissem refletidos como num espelho." (SANTOS, 1987, p. 60).

E assim, como o autor, atentamos para as analogias hoje utilizadas nas Ciências Naturais, por meio de modelos explicativos das Ciências Sociais. Santos (1987, p. 62) destaca como exemplo que o cientista "Lovelock, num livro recente sobre as ciências da vida, afirma que os nossos corpos são cooperativas de células.". O autor também defende que:

A ciência pós-moderna é uma ciência assumidamente analógica que conhece o que conhece pior através do que conhece melhor [...] o mundo, que hoje é natural ou social e amanhã será ambos [...] Não se trata de uma amálgama de sentido (que não seria sentido, mas ruído), mas antes de interações e de intertextualidades organizadas em torno de projetos locais de conhecimento indiviso. (SANTOS, 1987, p. 64).

Santos (1987) alerta que, mesmo hoje, nos movemos no campo teórico de autores que desenvolveram seus trabalhos intelectuais e científicos entre o século XVIII e primeiros vinte anos do século XX. Observa ainda que, sendo nós contemporâneos do final do ciclo hegemônico de uma determinada ordem científica, importa refletirmos sobre as contribuições do conhecimento científico para nossas vidas - quais seriam as positivas e as negativas. Nesse sentido, a Ciência da Informação não está alheia às questões concretas que ocorrem no mundo. Ao contrário, é parte, constitui-se e é constituída no mundo, na cultura.

Capurro (2003) refere-se ao esforço de apresentar a Ciência da Informação como um campo autônomo que possa fazer distinção do seu conceito de informação e do uso e da definição desta em outras ciências, bem como nos contextos culturais 
e políticos de diferentes épocas e culturas. O autor situa a evolução da Ciência da Informação dentro de três paradigmas, ressaltando, entretanto, a ausência de uma linearidade nesse processo - o paradigma físico é apresentado como aquele relacionado aos processos de armazenagem e busca da informação que parecem ignorar os aspectos semânticos e pragmáticos inerentes ao uso da informação, excluindo, portanto, o papel do usuário no processo informativo. Informação e Cultura, portanto, andam lado a lado, também segundo este autor.

Daí o paradigma cognitivo se basear no entendimento de que a finalidade da Ciência da Informação seria a recuperação dos conteúdos de informação, a partir da necessidade de um (ou vários) sujeito cognitivo, cujas necessidades não são supridas apenas pela existência e a disponibilização dos suportes informacionais.

Já o paradigma social se apresenta como aquele que considera a condição social e material da existência humana, prevalecendo, então, o entendimento de que a necessidade informacional dos sujeitos é construída nas relações e interações sociais.

Capurro (2003) argumenta que os sistemas de produção, recuperação e uso da informação deveriam ser elaborados considerando-se um grupo social concreto e inserido em determinadas áreas do conhecimento. $E$ defende a hermenêutica como paradigma da Ciência da Informação, na medida em que esta ciência trata de distinguir ofertas de sentido e processos de seleção desses sentidos dentro de um sistema inscrito na realidade de determinados grupos sociais.

No entanto, curiosamente, Rayward (1997) remontando às origens da Ciência da Informação, fala das tentativas de atendimento de necessidades informacionais socialmente constituídas, especialmente evidentes nas ações do documentalista Paul Otlet. Além disso, segundo Smit e Tálamo (2008), Otlet apresentava uma visão pós-moderna, sugerindo o valor intrínseco da informação e do conhecimento.

Smit e Tálamo (2008) ampliam a discussão em torno dos aspectos constitutivos da Ciência da Informação, situada na configuração de ciência pósmoderna que rejeita a ideia de conhecimento determinístico da ciência moderna, na perspectiva do conhecimento tradutor, compreensivo e interpretativo. Ainda nessa visão, segundo as autoras, o ato de conhecer não se separa do produto do conhecimento, relacionando, assim, sujeito e objeto. 


\section{Centralidade da cultura e Ciência da Informação}

Refletir sobre a cultura - entendida como os sentidos produzidos e compartilhados - no campo da $\mathrm{Cl}$, dentre outras possibilidades, significa pensar o significado dos objetivos da organização das instituições de informação, dos dispositivos culturais, desenvolvidos nos mais variados contextos de relações sociais, étnicas, políticas e econômicas. E, então, compreender - ou modificar - os processos de informação com mediações que viabilizem a apropriação da informação e da cultura, caso a perspectiva teórica e/ou prática tenha em mira o protagonismo cultural dos indivíduos, grupos e coletividades envolvidas. Concordamos, pois, com a observação de Hall (1997):

[...] sistemas ou códigos de significado dão sentido às nossas ações. Eles nos permitem interpretar significativamente as ações alheias. Tomados em seu conjunto, eles constituem nossas "culturas". Contribuem para assegurar que toda ação social é "cultural", que todas as práticas sociais expressam ou comunicam um significado e, neste sentido, são práticas de significação. Disso não decorre, entretanto, que as ciências humanas e sociais tenham sempre dado à "cultura" uma centralidade substantiva ou o peso epistemológico que ela merece. (HALL, 1997, p. 1).

Quase vinte anos já se passaram do registro dessa reflexão do autor e, especificamente, no campo da $\mathrm{Cl}$ no Brasil, seria necessário um esforço investigativo para entender se os trabalhos de pesquisas e/ou suas aplicações, revelam a consciência da centralidade da cultura para os estudos e o trabalho com a informação. Em termos práticos, parece vital questionar, sobretudo no campo da $\mathrm{Cl}$, porque importa definir o que seja mediação cultural e sua função para os modos de vida contemporâneos, na formação acadêmica e no desenvolvimento de práticas e construção dos saberes do mediador de informação e cultura. Qual o sentido de compreender as dinâmicas das relações e interações simbólicas entre os indivíduos, grupos e coletividades para os fazeres da mediação cultural nos dispositivos culturais? O que muda no desenvolvimento de ações educativas realizadas em dispositivos culturais e instituições de informação e memória quando seus realizadores formulam as estratégias de mediações tendo em mente propiciarem condições à apropriação da informação e da cultura e o protagonismo cultural? Que desafios políticos culturais são enfrentados na formulação dessas estratégias? 
Quem regula essas instituições? Há mecanismos forçando uma hegemonia cultural? Os conhecimentos produzidos nessas instituições e viabilizados por suas mediações são relevantes e significativos para o seu público? Quem constrói e define os sentidos que serão compartilhados?

Além disso, a cultura precisa ser vista como constitutiva das instituições e relações sociais, e assim também, constituir a análise dessas instituições e relações (HALL, 1997), ou seja, dos dispositivos culturais, sua história, concepções, modos de funcionamento, modos de atuar e intervir na cultura.

Consideramos que outro aspecto fundamental, além de compreender a centralidade da cultura nos estudos e práticas dos processos de informação, é refletir sobre o momento cultural atual e a sociedade de consumo.

Jameson (2006) considera apropriado utilizarmos o pós-modernismo como um conceito de periodização necessário ao entendimento das mudanças ocorridas nos momentos posteriores do alto modernismo. Essas mudanças vieram a desconfigurar os elementos inteligíveis de caracterização do modernismo, a partir de um período de transição que é, segundo o autor, notadamente, a década de 1960.

O pós-modernismo, de acordo com Jameson (2006), vai se apresentar no campo da cultura em forma de reações específicas e localizadas ao sistema estabelecido para produção e fruição das artes e para o fazer e o saber cultural. Mas, especialmente nesse aspecto, como forma de reação contra a separação entre a alta cultura e a cultura popular.

Segundo esse autor, quaisquer que sejam as características que se pretenda traçar "[...] não facilita em nada a tarefa de descrever o pós-modernismo como algo coerente, já que a unidade desse novo impulso - se existe - é dada, não por si mesma, mas pelo próprio modernismo que ele busca destronar." (JAMESON, 2006, p. 18). Então, Jameson (2006, p. 20) afirma que a função do conceito de pósmodernismo seria "[...] correlacionar o surgimento de novos aspectos formais na cultura com o surgimento de um novo tipo de vida social e de uma nova ordem econômica [...]". Portanto, é a nova ordem social do capitalismo tardio transformando a cultura, pela qual a expressão das mudanças na lógica cultural é especialmente significativa (sobretudo nas artes), segundo o autor, nos aspectos que ele chama de pastiche e esquizofrenia.

O pastiche, para Jameson (2006), é a mímica dos maneirismos e cacoetes de estilos, mas que se diferencia da paródia pela ausência da motivação para 
ridicularizar algo considerado "normal", já que o pós-modernismo rejeita a ideia de normalidade. O pastiche "é a paródia pálida, a paródia que perdeu o seu senso de humor." (JAMESON, 2006, p. 23).

Jameson (2006) observa também que perspectivas de teorias sociais pósmodernas e posicionamentos da área da cultura contestam a ideia de um eu singular, admitindo que essa ideologia alimentou as práticas estilísticas do modernismo. Para o autor, essa posição defende que o eu singular, enquanto construto, "é meramente uma mistificação filosófica e cultural, que buscou persuadir as pessoas de que elas 'tinham' subjetividades individuais e possuíam certa identidade pessoal singular." (JAMESON, 2006, p. 24).

Jameson (2006) desenvolve, com exemplos do campo artístico, como a pósmodernidade impõe o sentimento de incapacidade de invenção de novos estilos e nos coloca o pastiche como única alternativa. Segundo essa reflexão, a arte contemporânea se pauta na própria arte, nos aprisionando ao passado, o que nos remete à conclusão de Benjamin (1987, p. 171) de que "[...] o advento da primeira técnica de reprodução verdadeiramente revolucionária - a fotografia [...] levou a arte a pressentir a proximidade de uma crise [...] ela reagiu ao perigo iminente com a doutrina da arte pela arte, que é no fundo uma teologia da arte.".

Os indícios são de que a sociedade, agora, é incapaz de lidar com o tempo e a história, "como se, se por algum motivo, não pudéssemos mais, hoje, focar o nosso próprio presente, como se nos tivéssemos tornado incapazes de alcançar representações estéticas de nossa própria experiência atual”. (JAMESON, 2006, p. 29).

Além disso, o autor problematiza a questão afirmando que as narrativas pósmodernas não representam o passado histórico, mas as ideias e os estereótipos culturais sobre o nosso passado. E, ainda, argumenta que nossos hábitos perceptivos foram forjados no alto modernismo. É nesse sentido que Benjamin (1987) nos convida a atentarmos para as convulsões sociais dos períodos históricos se quisermos compreender os modos de percepção em cada um deles. Assim, inferimos que esses autores nos falam que entender os modos de percepção, trocas simbólicas e apropriações culturais na contemporaneidade, inclui o estudo e a compreensão das condições histórico-culturais.

De qualquer forma, sobre a ideia de pós-modernismo, Jameson (2006, p. 41) explica que podemos entender as rupturas e as mudanças que nos ajudam a 
caracterizar períodos como reestruturações, "aspectos que em um período ou sistema anterior eram subordinados, agora se tornam dominantes, e aspectos que tinham sido dominantes tornam-se agora secundários".

Essa perspectiva sobre o pós-modernismo e a sociedade de consumo permite-nos compreender que parece fundamental a $\mathrm{Cl}$ se debruçar sobre a lógica cultural e elaborar sua crítica da mediação para o consumo. Vemos, assim, a importância de distinguir e problematizar, também a partir do olhar da Ciência da Informação, as mediações e a formação de mediadores, já que estas tanto podem estar inscritas na lógica cultural de consumo como na que desenvolve resistência a essa lógica - a da apropriação e do protagonismo cultural.

Nesses termos, a mediação cultural poderá resgatar a cultura e sua complexidade num tempo em que os "fluxos" são representados - e não apenas vividos - com inevitabilidades históricas que tudo abarcam e subordinam. Vale, pois, refletir sobre a mediação e os mediadores culturais na $\mathrm{Cl}$. 


\section{MEDIAÇÃO E MEDIADOR CULTURAL EM QUESTÃO}

A mediação cultural vem sendo tema recorrente de reflexões nos campos das Ciências da Informação e da Comunicação, em diversas partes do mundo e, podemos considerar, que nos últimos anos também no Brasil. Esse interesse, em nossa visão, está ligado ao reconhecimento da centralidade da cultura nos processos e nas relações sociais que envolvem a informação e a comunicação. E na admissão de que para a análise desses processos e relações, o conceito de mediação cultural é operatório.

Também, de acordo com Dufrêne e Gellereau (2004a), sabendo que da mediação cultural

[...] muitos profissionais do mundo da cultura ou do sociocultural dela se valem (bibliotecários, serviços educativos ou pedagógicos de museus, serviços dos públicos nos lugares de espetáculos ao vivo, animadores socioculturais etc.) sem que isso recubra uma homogeneidade de práticas, de concepções.

Conforme Dufrêne e Gellereau (2004b), reconhecemos a mediação cultural como ato complexo. Seus saberes e fazeres invocam a teorização e não apenas a formatação de serviços.

Preocupadas com o recurso à noção de mediação, principalmente nas Ciências da Informação e da Comunicação, Dufrêne e Gellereau (2004b) afirmam que a noção é fundada nas metáforas da "passagem" e da "relação social" e que ela circula no âmbito da cultura e dos profissionais que lidam com o público, existindo, ainda, um exaltado desenvolvimento de reflexões e de críticas a respeito.

As autoras falam da complexidade de entender a mediação no mundo da cultura, na medida em que observam dois níveis de mediação - o da manifestação da mediação em atividades dos profissionais para e com um público, e o das políticas de desenvolvimento dessas ações culturais. No entanto, afirmam que essas mediações estão inscritas numa lógica de eventualização das ações culturais, tornando necessário recorrermos à noção de programação. Defendem que para entendermos ou explicarmos as práticas de mediação é preciso que nos coloquemos numa perspectiva sociológica, admitindo pensar a mediação cultural como sistema de mediações: "Pensar a mediação cultural como sistema de mediações é abolir as hierarquias implícitas entre as diversas formas de mediação e 
se interrogar sobre os princípios de inteligibilidade da ação cultural." (DUFRÊNE; GELLEREAU, 2004a). Além disso, sustentam que é preciso considerar a dimensão histórica e contextual dos interesses sociais que envolvem as políticas e manifestações de mediação. Afirmam, também, que:

Através da gama de mediações culturais, são as concepções da relação social e de finalidades da ação cultural que estão em jogo: aculturação a novas formas de expressão, criação de uma identidade para os projetos portadores de objetivos simbólicos, regulação social, concepção consumista etc. (DUFRÊNE; GELLEREAU, 2004a).

As autoras alertam para o engano de pensar, por exemplo, o acesso à cultura somente pelo que é oferecido pelas instituições culturais. Estas podem não considerar as práticas, os saberes dos indivíduos, dos grupos e da coletividade. Dufrêne e Gellereau (2004a), observam:

\begin{abstract}
Dizer que as tentativas de mediação vão permitir o acesso à cultura, é certo reconhecer faltas reais (a raridade de estruturas culturais em certas zonas) mas é do mesmo modo focalizar unicamente sobre as instituições culturais sem reconhecer numerosas práticas privadas e coletivas como culturais (jogos, vídeos, escuta musical, grupos musicais, fans-clubes...)
\end{abstract}

As autoras falam do caso francês em que a mediação cultural esteve atrelada à ideia de democratização da cultura, e assim se baseavam as políticas públicas para o setor, podendo ser observadas nos eventos promovidos por suas instituições culturais, pelo menos até os anos de 1970.

Como afirmam as autoras, a mediação cultural não está dissociada da ideologia e da política. E, nesse sentido, é preciso observar que, em vez da representatividade, a mediação cultural pode estar a serviço da regulação social.

A utilização da noção de mediação cultural pelo poder político privilegia por vezes o discurso emprestado ao público em detrimento do dos líderes culturais. O debate é tanto mais veemente que a especificidade do produto cultural de ser utilizado como um produto de imagem. (DUFRÊNE; GELLEREAU, 2004a).

As autoras nos apontam desafios importantes para pensarmos a formação do mediador cultural diante das concepções de cultura, das políticas, das pressões de regulação e de hegemonia cultural. 
Sobre a noção de mediação cultural, Perrotti e Pieruccini (2014) nos dizem que:

[...] talvez não esteja em causa simplesmente a pertinência teórica da noção. É possível que esteja em processo, a partir e com ela, uma ruptura de quadros epistemológicos que validaram concepções limitantes de informação e comunicação, reduzindo a mediação cultural à categoria meramente funcional ou instrumental [...] Ganha relevância, desse modo, o esforço de compreensão dos sentidos encerrados na noção de mediação cultural como ato de significação (Bruner, 1997), já que isso poderá representar um salto epistemológico fundamental, contribuindo tanto para a redefinição da noção, como para compreensões mais gerais acerca dos campos da Informação, da Comunicação e da Cultura. (PERROTTI; PIERUCCINI, 2014, p. 5).

Perrotti e Pieruccini (2014, p. 10-11), além de rebaterem o "senso comum" de que a mediação se resume ao interposto de um objeto ou saber cultural de um produtor para um receptor (transferência), afirmam que:

[...] a mediação cultural não se constitui meramente como jogo de saberes especiais ou especializados em vista de um fim determinado que the é exterior [...] a mediação não é somente um ato "funcional" ou de âmbito restrito; é também discurso, ato de produção de sentidos que se realiza no campo amplo e dinâmico da cultura.

A noção equivocadamente incompleta de mediação cultural que a materializa como um conjunto de procedimentos ou de estratégias, além de realização técnica ou formalização da disponibilização de dados, segundo Perrotti e Pieruccini (2014, p. 13), nos impede de observarmos que "é ação deontológica sobre a cultura e o mundo, modo especial de produção legitimada por imperativo ético-ontológico que ultrapassa e se distingue do imperativo da funcionalidade que sustenta 0 tecnicismo.".

Contemporaneamente, acrescenta-se à complexidade do ato e do "trabalho" de mediação cultural a sofisticação e até mesmo a intensificação das "guerras de representação" micro e macro regionais, aliadas às tecnologias digitais, e, portanto, a demanda por preparo sociopolítico do mediador cultural a ser construído em sua formação. Perrotti e Pieruccini $(2014$, p.17) ponderam:

O "sistema de mediações" de nossa época, marcado por descontinuidades, impessoalidades, conflitos de interesses de toda 
ordem, sobreposição de referências culturais díspares, presença crescente de organizações especializadas, de tecnologias de informação e comunicação que permitem o estabelecimento de relações mediadas por máquinas com alcance global, que comunicam à distância em "tempo real", não apresenta o mesmo estatuto dos sistemas de mediações tradicionais em que o conceito de comunidade tinha ainda algum sentido [...].

Já a dimensão pedagógica e educativa da mediação cultural se exemplifica na ideia de infoeducador, elaborada por Perrotti e Pieruccini (2008), como a de um profissional que possa dialogar com todos os responsáveis e interessados nas ações de mediação, além de, ele mesmo, ter domínio dos saberes informacionais, suas dimensões e lógicas. Seria, dessa forma, o "[...] mediador de processos de aprendizagem informacional, indispensáveis à apropriação simbólica e ao protagonismo cultural em nossa época" (PERROTTI; PIERUCCINI, 2008, p. 89). Mas qual é a formação ou quais são as formações que constituem o mediador cultural e o infoeducador? Que dimensões epistemológicas e pragmáticas estão sendo consideradas na constituição dessa formação?

Assim, também somos instigados a pensar a natureza afirmativa e criativa da mediação cultural, concordando com os autores que não se trata de simples passagem ou de transferência, mas de ato de criação de condições de relações. No caso do mediador cultural bibliotecário, Modesto (2007) alerta: "[...] necessitam ser criativos, promovendo estímulo à germinação de novas idéias para o desempenho de suas atividades".

Perrotti e Pieruccini acrescentam um dado diferenciado sobre a noção de mediação cultural: não se trata de vincular um público a uma cultura, mas viabilizar as condições para que o sujeito decida se quer se vincular, pois o protagonista decide. A decisão sobre o vínculo é dos atores. Para esses pesquisadores, a mediação cultural é o ato de criar condições culturais e cognitivas para os embates entre sujeitos e signos, compreensão que adotamos neste trabalho.

Daí a proposta da Infoeducação, para o caso do Brasil, em que a exposição e o acesso convivem com a invisibilidade e a exclusão. É preciso, de acordo com os autores, reatar ou resgatar os vínculos entre a mediação e a educação, as vivências culturais e as aprendizagens, afim de que os domínios da mediação cultural permitam que os sujeitos desenvolvam saberes e fazeres culturais específicos e necessários à apropriação cultural, para o protagonismo cultural que, para Perrotti e 
Pieruccini (2008), é a participação e afirmação do sujeito na vida cultural, de forma individual ou coletiva, produzindo e criando significados e sentidos, não apenas usando ou consumindo cultura. Como reflete Canclini (2008, p. 136), o protagonista participa da construção de seu "próprio capital intelectual". A imagem abaixo nos faz refletir sobre uma participação afirmativa.

Figura 2: Protagonistas participam da vida cultural afirmativamente

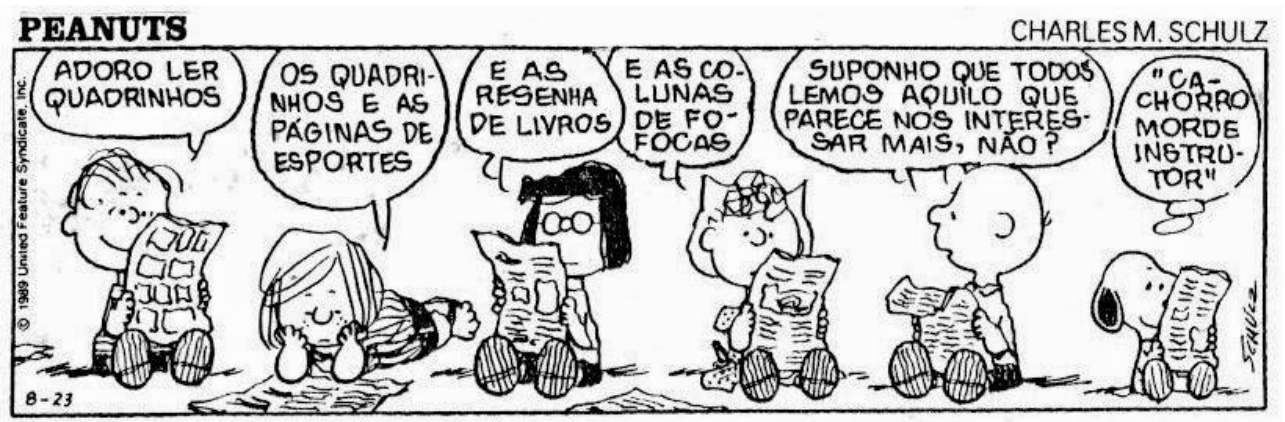

Fonte: Valdez, T. Tirinhas de quadrinhos, charge, imagem, humor de biblioteca, bibliotecário, leitura e livros ${ }^{2}$.

Num texto publicado originalmente em língua francesa, em 2003, o pesquisador Jean Davallon, da Universidade de Avignon e da Região de Vaucluse, pergunta se a existência de uma terceira parte, autorizada e "neutra", que age no sentido de colocar em comunicação duas partes em desentendimento, como na mediação jurídica, pode nos ajudar a definir a mediação cultural.

No entanto, o autor argumenta que, funcionalmente, a definição de mediação cultural envolve a aproximação do público a saberes e objetos simbólicos - objetos culturais -, por meio da construção de interfaces que implicam mediadores e situações concretas de mediação. Mas também, entre outras definições, mediação pode ser entendida como a prática profissional do mediador. E assim, sua terminologia necessita de permanente contextualização.

\footnotetext{
${ }^{2}$ Disponível em: http://1.bp.blogspot.com/1qaonyd5XCE/U78zNM4pDCl/AAAAAAAADic/7DWcetYpw7k/s1600/12_10_10.jpg. Acesso em: jun. 2015.
} 
Davallon (2007) localiza e passa a categorizar o entendimento do termo mediação em cinco áreas: mediação mediática, mediação pedagógica, mediação cultural, mediação institucional e mediação técnico-social.

A mediação mediática depende da figura do comunicador como mediador, cuja ação é a de reenviar, ou mesmo traduzir, o texto do objeto cultural - ou seu discurso - para o público. A mediação pedagógica está vinculada à figura do formador, do educador, na medida em que a ação é a de planejar ou regular interações visando a aprendizagem do objeto cultural. Quanto à mediação pedagógica o autor pergunta se a posição de mediador "[...] deverá ser assegurada somente por formadores, ou poderá ser também por dispositivos técnicos fornecidos pelos formadores?" (DAVALLON, 2007, p. 7).

A mediação cultural contém aspectos e faz uma síntese da mediação mediática e da mediação pedagógica, privilegiando a dimensão teórica - dos saberes -, remetendo à mediação da informação e aos aspectos sociais ou semióticos da comunicação.

No entanto, o autor afirma que há ainda vários outros empregos do termo mediação que, do seu ponto vista, poderiam ser categorizados numa "mediação institucional", abarcando perspectivas políticas e sociológicas que irão requisitar a problematização das questões de hegemonia e diversidade cultural.

Por fim, o autor fala de uma mediação que seria técnico-social. Técnica pela razão do uso de tecnologias estruturarem as práticas; social porque o sentido atribuído às práticas são negociados na comunicação.

Em todo o caso, o autor deduz, em sua própria categorização, que nas diversas noções de mediação, a presença do mediador varia em forma. Mas a sua ação, em qualquer das noções, apresenta quatro características: a ação é moldada para o sujeito e produz efeito nele; a ação permite que o sujeito modifique ou ressignifique o objeto cultural e a si próprio; o mediador é essencialmente humano, mas a mediação pode se constituir na ação humana objetivada num dispositivo; a ação do mediador é impactante no seu ambiente social.

Para Davallon (2007), a noção de mediação é requerida quando se quer descrever uma ação transformadora de uma situação ou de um dispositivo de comunicação e não simplesmente para denominar a interação entre dois polos. E, portanto, defende a hipótese de que se recorre à mediação quando há falha ou 
inadequação da comunicação, tanto no compartilhamento de informação quanto nas relações de interação.

Inferimos, portanto, que, nesse caso, a mediação seria a ação que pode transformar os significados e o estado de incomunicabilidade entre os bens culturais e um indivíduo, grupo ou coletividade. Então, o mediador cultural pode ser entendido como o articulador entre os bens culturais - saberes e objetos simbólicos - e um indivíduo, um grupo ou uma coletividade, por meio de dispositivos ou recursos instrumentais para acesso e apropriação desses bens.

Para Davallon (2007), a questão essencial é saber a natureza da mediação, perguntando se o que conseguimos observar é diferença de forma ou natureza, uma vez que é nesse ponto que as abordagens do tema mediação parecem divergentes.

Davallon apresenta quatro autores que propuseram definição de mediação, chamando a atenção para o fato de que esses autores estão inseridos no campo das Ciências da Informação e da Comunicação: Bernard Lamizet, Jean Caune, Louis Quere e Antoine Hennion.

O autor afirma que Bernard Lamizet e Jean Caune mostram claramente em suas obras o objetivo de desenvolver uma teoria da mediação. Mas, enquanto Lamizet nos indica que a natureza da mediação está na reflexividade e na representação, Caune nos indica que está no símbolo e na própria cultura, entendida como a manifestação da referência de mundo de indivíduos.

Já Louis Quere, para Davallon (2007), demonstra uma visão intermediária entre as de Bernard Lamizet e a de Jean Caune, sugerindo estar a natureza da mediação nas trocas simbólicas da interação social.

Vemos, assim, desenhar-se uma diferença nítida entre os três autores precedentes, quanto à maneira como pensam o terceiro - e, portanto, a mediação -: o primeiro parte da linguagem e do sujeito; o segundo do processo de instituição da cultura; o terceiro de uma antropologia do espaço público. Em contrapartida, podem-se destacar três constantes. (i) O emprego das mesmas componentes para definir a mediação: a intersubjectividade, a linguagem, 0 político. (ii) $O$ princípio segundo o qual a comunicação social é um produto da mediação e não o inverso. (iii) $\mathrm{E}$, acrescentaria eu: a mediação constrói-se em torno de um ponto de fuga - chamado exterioridade, neutro, negativo, conforme os casos - que intervém no processo de comunicação sem que aqueles que nele participam possam ter controle sobre ele. É, no fundo, o que designa, sob diversas modalidades, a figura do terceiro que Louis Quéré descreve enquanto terceiro simbolizante. (DAVALLON, 2007, p. 14). 
No entanto, o autor nos apresenta a noção que a obra de Antoine Hennion nos dá de mediação, ressaltando que o mesmo buscou não teorizar a mediação, mas analisá-la sociologicamente. E nos convida, então, a observar que há um ponto de fuga em torno do qual a mediação pode ser considerada a construção social de relações que transforma e produz tanto o objeto cultural quanto o público. "Um exame do fato de que, a partir das mediações, qualquer coisa se passa, produz-se um acontecimento, uma passagem, que não deixa nada como dantes" (DAVALLON, 2007, p. 15).

O autor segue citando a obra de Franco Crespi, afirmando que ela é de grande auxílio para pensar a noção de mediação, quando nos coloca que a mediação assinala o funcionamento antropológico e que, nessa dinâmica humana, há uma ordem simbólica constituída, ao mesmo tempo, de consenso e de diferença.

Davallon afirma também que a dificuldade em conceituar mediação nos indica a necessidade de um esforço teórico, que já vem sendo feito, essencial para pensarmos conceitos científicos dentro das Ciências da Informação e da Comunicação.

O autor defende que precisamos recorrer às definições de mediação para analisar os dispositivos comunicacionais (que no seu ponto de vista são técnicos, sociais e significantes) como um exercício científico, e não refletir sobre a mediação como um exercício filosófico.

Davallon acredita que a noção de mediação, nas Ciências da Informação e da Comunicação, pode servir para designar as formas e modalidades do funcionamento simbólico. E propõe o modelo da mediação como alternativa às definições de comunicação como transmissão de informação, ou seja, como interação de sujeitos sociais - "o que o modelo da mediação faz aparecer é menos os elementos (a informação, os sujeitos sociais, a relação, etc.) do que a articulação desses elementos num dispositivo singular (o texto, o média, a cultura)". (DAVALLON, 2007, p. 23).

No trabalho de Leonardo Costa (2011) há um subcapítulo intitulado: Médiation culturelle - muitas nomenclaturas, pouca distinção? em que o autor pergunta "do que trata a mediação cultural?", passando a uma revisão da literatura francesa sobre o tema.

Costa (2011) afirma que há um grupo de definições nos estudos franceses que colocam a mediação como a produção de sentido nas experiências com as 
obras de arte, compartilhadas por meio da linguagem e onde as políticas culturais funcionam como a expressão da representação social e o mediador como um intermediário para que as obras sejam experimentadas pelo público.

Mas, um problema de definição que ocorre com frequência nos estudos franceses diz respeito justamente a essa posição intermediária. Podemos entender esse mediador como aquele profissional que no sistema cultural trabalha com diversas linguagens, sabendo dialogar com as fontes de financiamento, os artistas e os públicos. De fato, essa figura faria uma mediação entre os diversos atores que de algum modo precisam entrar em comunhão num determinado momento. (COSTA, 2001, p. 42).

Sendo assim, parece que a observação de Costa (2011) se coaduna com a de Dufrêne e Gellereau (2004b) no sentido de que é necessário pensar também a mediação cultural como um sistema de mediações. Da mesma forma, sua consideração diz respeito à ideia do infoeducador desenvolvida por Perrotti e Pierrucini (2008).

Por outro lado, uma distinção fundamental, estabelecida por Almeida Júnior (2009), é que, ao nos referirmos ao conceito de mediação, devemos considerar as diferenças entre as "mediações implícitas" e as "mediações explícitas". Com isso, o autor chama a atenção para o fato de que os dispositivos culturais, como as bibliotecas, realizam processos de mediação, tanto pelo modo como organizam e tratam seus espaços físicos - acervos, fluxos de funcionamento, sistemas de gestão -, como pelas ações - interlocuções diretas, interpessoais, com os diferentes públicos que a frequentam. Tal fato é relevante, uma vez que nem sempre mediações "implícitas" e "explícitas" estão em harmonia ou são consideradas como tal. Como tanto umas como outras atuam sobre os processos de apropriação e indicam modos e formas de compreender a própria mediação, é de fundamental importância considerar tal distinção nesta tese:

A primeira, a mediação implícita, ocorre nos espaços dos equipamentos informacionais em que as ações são desenvolvidas sem presença física e imediata dos usuários. Nesses espaços, como já observado, estão a seleção, o armazenamento e o processamento da informação. A mediação explícita, por seu lado, ocorre nos espaços em que a presença do usuário é inevitável, é condição sine qua non para sua existência, mesmo que tal presença não seja física, como, por exemplo, nos acessos à distância em que não é solicitada a interferência concreta e presencial do profissional da informação. (ALMEIDA JÚNIOR, 2009, p.92-93). 
Portanto, pensar desde a organização da informação, a condição do público , entendendo-o como categoria formada por indivíduos que precisam protagonizar a vida cultural, subentende a atuação de um mediador cultural e um sistema de mediações que intervém, codificando ou decodificando, atuando na negociação de sentidos, de preferências culturais, de gosto, de vínculos com a informação e o conhecimento. Essas mediações não impõem, oprimem, subestimam ou presumem. E assim, concordamos com Dufrêne e Gellereau (2004a) quando expõem que:

[...] o que falta hoje é uma visão política das mediações, sua inscrição em políticas de democratização, de descentralização que entram em estratégias de formação de representações simbólicas: elas devem ser estudadas tanto nas formações profissionalizadas quanto nas formações de cultura geral (tradução nossa). 


\section{APROPRIAÇÃO CULTURAL}

Segundo Serfaty-Garzon (2003, p. 27) a noção de apropriação nos remete à ideia de adaptação de algo para um determinado uso ou mesmo à ação de tornar algo próprio. Nessa adaptação ocorreria a ação de um sujeito no sentido de modificar o objeto para alcançar harmonia. E, nesse sentido, apropriar-se é tornar algo próprio e expressivo. "A apropriação é assim ao mesmo tempo uma apreensão do objeto e uma dinâmica de ação sobre o mundo material e social em uma intenção de construção do sujeito." (tradução nossa).

A autora afirma que o uso sociológico do conceito de apropriação tem origem em Marx, pela alusão à tese de que é pela retomada de posse dos produtos gerados pelo trabalho que os indivíduos interiorizam saberes e o saber-fazer, o que "constitui o coração da apropriação".

Além disso, Serfaty-Garzon nota que, nessa perspectiva marxista, a apropriação se realiza interiormente, ao mesmo tempo em que é uma experiência mediada pela sociedade, por meio de modelos transmitidos. No entanto, observa que é possível pensar a apropriação não exclusivamente pela retomada de posse e pelo trabalho, mas por uma dinâmica de elaboração de sentido.

Para Perrotti e Pieruccini (2008, p. 74), a apropriação é ação afirmativa com e sobre significados negociados que "[...] diferencia e constitui os negociadores como sujeitos da cultura, protagonistas, cidadãos". Além disso, para eles, a apropriação dos bens simbólicos se dá em processos dinâmicos de construção cultural e as mediações socioculturais são constituintes desse processo. Mas, principalmente, "[...] apropriar-se de informação e cultura é ato próprio de protagonistas, categoria que no âmbito da educação e cultura se distinguem das de usuários e de consumidores culturais [...]" (PERROTTI e PIERUCCINI, 2008, p. 77). Por tal razão, os autores distinguem apropriação de assimilação cultural, distinção fundamental, pois apontam para objetivos políticos e culturais distintos. Assim, as ações socioculturais dos mediadores propõem às pessoas uma "[...] reflexão crítica sobre a obra cultural, sobre si mesmas e sobre a sociedade [...]" (COELHO NETTO, 2004, p. 34).

A mediação cultural, nesses termos, é a atividade que visa proporcionar igualdade de oportunidades e condições para que as pessoas estejam inseridas como protagonistas no percurso cultural e, assim, em processos dinâmicos de 
apropriação, possam se apropriar, ressignificar e reconstruir os bens culturais, bem como inventá-los, defini-los e renová-los.

Para Canclini (2009), cultura é parte das práticas sociais e pode ser entendida como processo de produção, circulação e consumo de significações na vida social. Esse autor propõe que nos detenhamos no estudo, não da "cultura", mas do "cultural", como o "conjunto de processos através dos quais dois ou mais grupos representam e intuem imaginariamente o social, concebem e geram as relações, ou seja, as diferenças“. (CANCLINI, 2009, p. 499).

Dessa forma, a apropriação cultural é o movimento de tornar próprios saberes e objetos construídos, transformados e significados pelos sujeitos nas relações socioculturais. Sem esquecer que esses sujeitos estão submetidos às relações de poder que afetam e tencionam as interações.

$\mathrm{E}$, se a apropriação cultural também é resultado de uma elaboração de sentido que, no entanto, é mediada por modelos transmitidos, conforme a perspectiva marxista, a questão está, portanto, situada na Educação. Contudo, compreendemos que uma educação para a apropriação cultural seja a que Russell (2002) defende como mecanismo de ampliação de interesses. Estes se tornariam cada vez menos pessoais e cada vez mais coletivos e públicos. Os interesses pessoais se aproximariam cada vez mais dos gerais. Trata-se de educação diferente daquela voltada ao consumo, à assimilação e à reprodução culturais.

Por isso, a apropriação cultural não estaria apenas ligada à criação ou a inovação produzida pelo sujeito, tomado isoladamente, sem vínculos, mas, essencialmente, ao protagonismo cultural exercido como ato relacional, conectado à esfera pública. Apropriar-se de cultura significa, assim, não somente tomar posse de uma herança cultural ou identificar-se com os elementos culturais de uma sociedade e sim tornar próprios saberes e fazeres envolvendo objetos e fenômenos culturais, dando-lhes sentido, numa dinâmica de desconstrução, reconstrução e invenção desses próprios saberes, fazeres, objetos (PERROTTI; PIERUCCINI, 2008).

Tal processo se dá em negociação entre os protagonistas da cultura (OLIVEIRA, 2014). Esses protagonistas não apenas reproduzem ou consomem, mas negociam a cultura e seus significados.

Mas o que é necessário para que indivíduos, grupos e coletividades sejam protagonistas da cultura e apropriem-se dela? Que contribuição é dada pela 
mediação e pelo mediador cultural para que o processo ocorra? O que é necessário ao mediador cultural para favorecer a apropriação cultural?

Tratando da apropriação da herança cultural, François de Singly (2009), desenvolve a noção de mobilização para defender que não basta ser herdeiro de um grupo familiar com determinada posição e origem social, para que o indivíduo se aproprie de sua herança cultural. A origem social para Singly não é suficiente para a apropriação da herança cultural, visto que as experiências e trajetórias de cada um dos indivíduos são integrantes do processo de apropriação.

Desse modo, o esforço do grupo familiar, no sentido de garantir que o herdeiro de fato herde, está associado ao investimento pessoal do herdeiro, no processo que o autor chama de mobilização. Segundo Singly (2009, p.15), "Ele deve não somente aceitar fazer os esforços necessários para dar continuidade à linhagem familiar", mas também trabalhar para isso de forma autônoma, pois "O indivíduo dilapidador sonha em ser ele próprio, sem dever nada a ninguém e, muito menos, à geração precedente".

$\mathrm{Na}$ dinâmica da apropriação, o autor chama atenção para a dimensão relacional que é pedagógica e envolve, sobretudo, pais e professores - "Ele [0 professor] dá vida ao aluno, dando a ele a impressão de ser único, de estar inserido em uma relação pessoal e não somente em uma distribuição anônima do saber." (SINGLY, 2009, p. 16). E mais: "os indivíduos, jovens e adultos, apenas chegam a mobilizar seus recursos, mesmo herdados [...] se eles recebem suficientemente marcas de atenção pessoal”. (SINGLY, 2009, p. 17).

Por isso, consideramos que a dimensão pedagógica da mediação cultural caracteriza o mediador cultural também como um educador que atua desenvolvendo relações individuais e públicas e que trabalha com a intersubjetividade, a autonomia e a política.

Além disso, somos instigados a questionar, mediante as observações do autor, se a apropriação cultural é necessariamente resultante de uma herança, embora os herdeiros sejam beneficiados por condições privilegiadas de acesso aos circuitos e aos bens culturais. Singly (2009) nota que é preciso observar a dinâmica das dimensões sociais e privadas da vida do indivíduo e assim repensar o modelo de herança na contemporaneidade. Para ele, "os herdeiros de hoje decidem, por duas razões, ser herdeiros: trabalhando para acumular recursos que podem ser 
reconhecidos pela instituição escolar [...] e fazendo opção por esta ou aquela parte da herança, moral e cultural." (SINGLY, 2009, p. 27).

Quanto aos não herdeiros, afirmamos que podem ser desenvolvidas as condições para a apropriação da cultura, sobretudo nos espaços pedagógicos e de relações que devem ser os das escolas e demais dispositivos culturais como as bibliotecas e os museus. Para os dois casos - dos herdeiros e dos não herdeiros as condições incluem liberdade de escolhas, negociação de sentidos e dos fins culturais.

Assim, também entendemos que a mediação cultural, em suas estratégias e práticas, evidencia e favorece as relações interpessoais, especialmente as que envolvem o mediador. Evidentemente, as capacidades para o desenvolvimento de relações interpessoais, assim como para a prática pedagógica, se fazem importantes na formação do mediador cultural.

$E$, se para favorecer a apropriação cultural é preciso desenvolver as competências pedagógicas e educacionais do mediador, da mesma forma é essencial ter clareza das concepções de educação, e de construção de conhecimentos, que serão adotadas, na perspectiva de uma dialética de filiação e emancipação, tanto de herdeiros como de não herdeiros, como observa Singly (2009).

Em decorrência, podemos afirmar que uma das chaves para viabilizar a apropriação cultural de indivíduos, grupos e coletividades é o entendimento da mediação cultural como recurso privilegiado para o desenvolvimento de relações e conhecimentos culturais a serem construídos em ambientes de formação - formais e não formais.

Ao mencionar aspectos das diversões das populações urbanas, Russell (2002, p. 42) defende que mesmo a promoção do "conhecimento inútil" poderia se dar por meio da educação: "Não resta dúvida que essas diversões são melhores que nenhuma diversão, mas nada que se compare com as de uma população que tivesse adquirido, através da educação, uma ampla gama de interesses inteligentes não relacionados ao trabalho.".

Nesse caso, a mediação cultural desenvolvida pelo "educador" é aquela que visa a apropriação e o protagonismo de indivíduos, grupos e coletividades, pois não pretende controlar a oferta de bens pré-definidos, dados, estabelecidos, que precisam ser acessados por meio de sua intervenção. A intervenção na perspectiva 
de um mediador cultural "educador" que pretende viabilizar a apropriação e o protagonismo cultural é no sentido de uma dialética de emancipação e filiação, construção dinâmica de identidades individuais e coletivas.

As ações educativas desenvolvidas por mediadores culturais, que reconhecem o paradigma da apropriação e sua responsabilidade social em viabilizála, incluem a promoção do "conhecimento inútil", que é substancial para a educação planetária sobre a qual discorre Morin (2005). Para desenvolvermos a educação planetária, Morin (2005) defende a incorporação da noção de complexidade no sistema educativo: "Vejam, a palavra complexidade. Ela vem do latim complexus, 'aquilo que é tecido'. Vemos, então, que nosso sistema educacional nos torna incapazes de conceber a complexidade, isto é, as inumáveis ligações entre os diferentes aspectos do conhecimento.".

Morin (2005) defende a necessidade de se desenvolver conexões e relações de conhecimentos para uma educação planetária. Mas não só isso. O autor afirma que se faz necessário conhecer o conhecimento:

[...] a questão do conhecimento, ou seja, de conhecer o conhecimento não pode ser algo reservado a uma elite de estudiosos da epistemologia, confinados num ensino restrito, filosófico. É algo que deve começar no ensino primário e prosseguir no ensino secundário, e continuar na universidade.

Um exemplo pode ser visto no quadrinho da Figura 3.

Figura 3: Conhecer o conhecimento, indagar para se apropriar

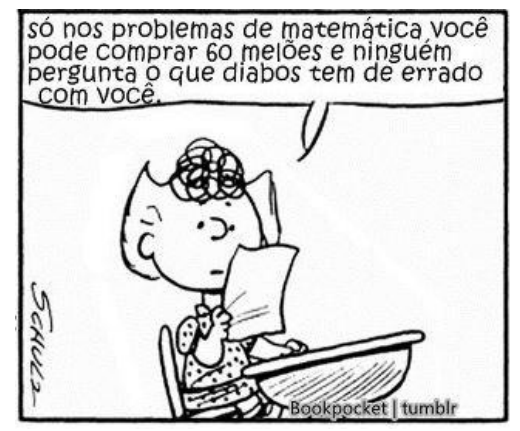

Fonte: BOOKPOKET ${ }^{3}$

\footnotetext{
${ }^{3}$ Disponível em: http://bookpocket.tumblr.com/post/6733744682. Acesso em: jun. 2015.
} 
$\mathrm{Na}$ construção do "conhecimento cultural" - como parte do conjunto de conhecimentos inúteis de que trata Russel (2002) - está contida a marca cultural que, segundo Morin (2005), adquirimos desde criança por meio de fontes psicológicas e fontes culturais presentes em linguagem, ideias e crenças. $E$, portanto, a educação planetária de Morin (2005) parte do princípio de que o conhecimento individual está imbricado no conhecimento social ("útil” ou "inútil”) que é parte de um todo planetário: "Outrossim, cada um de nós é uma pequena parte da sociedade, mas a sociedade, como um todo, se encontra em cada indivíduo através da linguagem, da cultura, da família.”. Apropriar-se, nesses termos, é estabelecer nexos, relações de significação entre o particular e o geral, a parte e o todo, o individual e o social, o local e o "planetário". É definir e definir-se, nomear e nomearse! 


\section{INTERCULTURALIDADE, ENTRECULTURALIDADE E NEGOCIAÇÃO CULTURAL}

Partimos de uma inquietação com a forma simplificada que a mediação cultural vem sendo tratada na formação do bibliotecário, resumida nessa possível oração - "Tudo é mediação no fazer do bibliotecário. Media quando organiza, dá acesso e gerencia informação, acervos ou bibliotecas. Já sabemos o que é um mediador!". Podemos acrescentar: sabemos?

Pensar a mediação cultural em contextos heterogêneos é pensar em ambientes marcados por tensões e conflitos, não apenas marcados por interesses comuns. Nesse sentido, é preciso pensar a formação do Bibliotecário partindo não de um desejo de consenso sobre currículos e disciplinas adequadas à necessidade de mediação cultural, mas, sobretudo, da preocupação ao atendimento das demandas específicas da biblioteca pública, da escolar, da "multicultural", da especializada, da comunitária, dentre outras. Se indagarmos quanto às competências para planejar e desenvolver programas para o "diálogo intercultural" como prescrito no Manifesto sobre a Biblioteca Multicultural, podemos perguntar: a formação do bibliotecário tem sido pensada nesse sentido? Por outro lado, esta é uma demanda social para este profissional. Ou será que devemos esperar de outra profissão a responsabilidade por este tipo de atuação em bibliotecas?

Nesse sentido, o cuidado com a ideia de multiculturalismo é eminente. E, somos levados a problematizar o adjetivo "multicultural", usado para adjetivar a biblioteca nos termos do próprio manifesto, uma vez que os conceitos de interculturalidade ou entreculturalidade é que nos aproxima da realidade de um mediador cultural que precisa atuar como negociador cultural para o "diálogo intercultural".

As dificuldades a serem enfrentadas pelo mediador, esse negociador cultural, exigem, portanto, que em sua formação, especialmente, sejam problematizados conceitos como multiculturalismo, interculturalidade e entreculturalidade.

Dessa forma, torna-se importante saber que o conceito de multiculturalismo, por exemplo, na medida em que parte de uma ideia de convivência "lado a lado" de culturas "[...] pode forçar os nacionalismos, bem como as explicações biossociais de raça e de etnicidade a ocupar posturas mais defensivas" (GILROY, 2007, p. 290). 
No multiculturalismo a hegemonia pode se travestir de tolerância, garantindo um "espaço" para o outro - o "exótico", e evitando a negociação. Além disso, formas culturais viram apenas negócio e não objetos de trocas de sentidos entre protagonistas. Para Gilroy, "imoralidade e corrupção do mundo superdesenvolvido, aprisiona o Outro primitivo em uma fantasia de inocência, que pode apenas ser catastrófico para todos os lados envolvidos nisso" (GILROY, 2007, p. 300).

O que isso pode acarretar é apenas troca de poder, uma cultura se submeter à outra ou um pouco de visibilidade de grupos antes não representativos. É o que ocorre, por vezes, no caso da "cultura negra", segundo Gilroy (2007, p. 319), com expressões de: "[...] um grupo privilegiado que mistifica o seu próprio distanciamento crescente das vidas da maioria das pessoas negras, e cujas prioridades, hábitos e gostos não podem mais ser considerados como indicadores, que se autolegitimam, da integridade racial". O autor propõe "uma teoria de culturas relacionais e de cultura como relação", impelindo-nos a repensar a noção de cultura plural e a própria noção de cultura.

As "dimensões culturais" que relacionam poder, governo nacional e incompatibilidade entre os grupos sociais são complexas. Pois, segundo Gilroy, essas dimensões evidenciam que "a cultura detém um outro conjunto de significados que dá apoio, mas também resiste aos conflitos políticos que emergiram com sua pluralização, racialização e etnificação" (GILROY, 2007, p. 332).

Também preocupado com o multiculturalismo, Canclini (2009, p. 26-27) nos alerta para o cuidado em não "asfixiar" a criatividade e a inovação linguística e estética. E, nos convoca a fazer a diferenciação entre multiculturalidade e multiculturalismo:
A multiculturalidade, ou seja, a abundância de opções simbólicas,propicia enriquecimentos e fusões, inovações estilísticas mediante empréstimos tomados de muitas partes. 0 multiculturalismo [...] entrincheira-se no local sem problematizar sua inserção em unidades sociais complexas de ampla escala.

$\mathrm{Na}$ direção da apropriação cultural é essencial sabermos diferenciar os termos e entender formas pelas quais os conceitos podem se materializar nas relações socioculturais, pois, "[...] o problema não é manter 'campos sociais alternativos', mas ser incluídos, chegar a se conectarem, sem que isso atropele sua diferença nem os condene à desigualdade. Em suma, ser cidadãos em sentido 
intercultural." (CANCLINI, 2009, p. 66). O autor, portanto, apresenta as implicações dos termos multiculturalidade e interculturalidade discutindo as condições sociais e midiáticas em que os indivíduos se deparam com suas discrepâncias e conflitos culturais.

Conforme Canclini (2009, p. 238), "Estamos numa época em que cresce a aceitação da multiculturalidade na educação e nos direitos políticos, mas estreita-se a diversidade na indústria cultural". O autor enfatiza a necessidade de "[...] prestar atenção às misturas e aos mal-entendidos que vinculam os grupos [...] entender cada grupo deve-se descrever como se apropria dos produtos materiais e simbólicos alheios e os reinterpreta [...] também as barreiras em que se entrincheiram, a perseguição ocidental a indígenas e muçulmanos [...]" (CANCLINI, 2009, p. 25).

O desenvolvimento de mediações culturais exige que se considere que os significados culturais resultam de negociações. Canclini (2009, p. 237) afirma que:

[...] é necessário educar para a multiculturalidade, ou melhor, para a interculturalidade. Uma interculturalidade que propicie a continuidade de pertencimentos étnicos, grupais e nacionais, junto com o acesso fluido aos repertórios transnacionais, difundidos pelos meios de comunicação urbanos e de massa.

A cultura também é uma esfera social onde indivíduos e grupos se afirmam o ambiente de construção de identidades -, como argumenta Hall (2006). Para ele, ao ponderar sobre a identidade cultural na pós-modernidade, a negociação cultural se dá na realidade do "[...] sujeito pós-moderno, atravessado por um processo de identificação [...] provisório, variável e problemático [...] conceptualizado como não tendo uma identidade fixa, essencial ou permanente" (HALL, 1997, p.13). Por isso, é num cenário de identidades cambiantes em que somos, necessariamente, levados à discussão das questões que envolvem a multiculturalidade e a interculturalidade, imprescindíveis ao mediador cultural. Sobre essa questão, Canclini (2009, p. 17) esclarece:

De um mundo multicultural - justaposição de etnias ou grupos em uma cidade ou nação - passamos a outro, intercultural e globalizado [...] ambos os termos implicam dois modos de produção do social multiculturalidade supõe aceitação do heterogêneo, interculturalidade implica que os diferentes são o que são, em relações de negociação, conflito e empréstimos recíprocos. 
A mediação cultural é constituída na relação de troca e nas negociações de repertórios culturais, tendo como cenário diferenças e conflitos, não visa a prescrição, regulação, assimilação, controle e hegemonia cultural, mas à apropriação e o protagonismo cultural. A figura abaixo esclarece sobre a visão distinta da que está implicada na mediação para apropriação e protagonismo cultural.

Figura 4: Mediação para o controle ou para apropriação e protagonismo cultural?

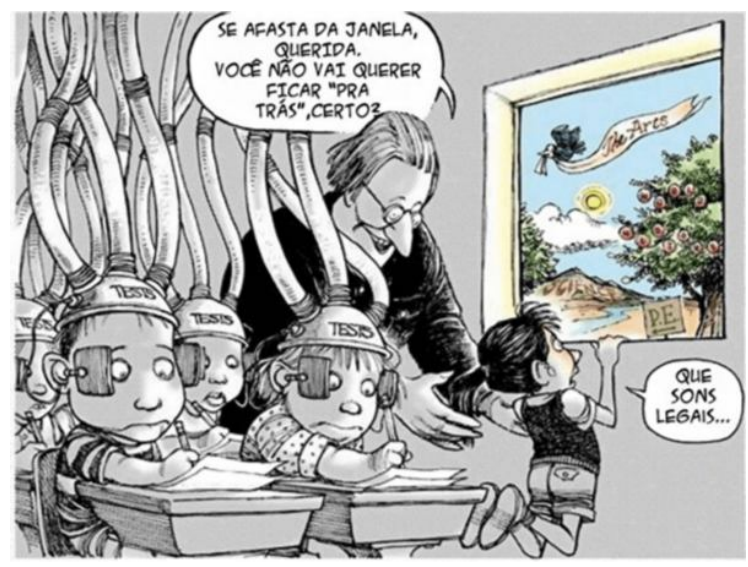

Fonte: Camargo, A. 18 Quadrinhos contundentes para entender por que colocar uma criança em uma escola tradicional é um desastre ${ }^{4}$.

Corona e Pérez Daniel (2009) chamam a atenção para o fato de que o multiculturalismo também relega certos grupos e coletividades à mera valorização turística desrespeitando, por exemplo, a necessidade de inclusão e desenvolvimento de suas identidades e culturas. Para as autoras, mesmo a ideia de interculturalidade sugere a existência de generalização, igualdade e reciprocidade, que seriam, de fato, irreais. Dão, assim, preferência ao sufixo "entre" por acreditar que a entreculturalidade traduz a realidade da necessidade de diálogo a partir de elementos que exigem acordo e, portanto, negociação, assentada sobre diferenças.

A entreculturalidade na visão de Corona e Daniel (2009) se dá na existência de um espaço comum de "respeito" à identidade étnica e política, permitindo a manifestação e visibilidade exigidas para a negociação cultural. Esse espaço

\footnotetext{
${ }^{4}$ Disponível em: https://medium.com/brasil/18-quadrinhos-contundentes-para-entender-por-que-colocaruma-crian\%C3\%A7a-em-uma-escola-tradicional-\%C3\%A9-um-d66d182c3d77\#.eyhnp9qfw. Acesso em: jun. 2015.
} 
público, conforme as autoras, deve ser construído com a participação de todos, sem a perspectiva de fusão que ocorreria na interculturalidade, mas na perspectiva de se conservar a unicidade e querer enriquecer no diálogo e no conflito.

Nesse sentido, não é o bastante para o mediador cultural saber que as relações se dão num contexto intercultural ou entrecultural. Ele desenvolve saberes e fazeres de negociação informacional/cultural, consciente de que os conflitos, as lutas de representações ou de reconhecimento são o motor da evolução social, conforme enfatiza Zaidan Filho (2012).

Para Oliveira (2014, p. 230-231), "O mediador negociador [...] nó essencial das tramas que possibilitam a invenção, a criação e recriação de si e do outro [...] abre possibilidades novas de sentidos com sua atuação, seus modos de ser, de se expressar, de se vincular [...]". Portanto, temos em mente o que afirma ainda essa pesquisadora no trecho a seguir:

[...] considerar a negociação cultural implica reconhecer [...] as características micro e macro dos espaços onde ocorrem as negociações, conhecer e reconhecer os negociadores, ou seja, o que está em jogo e implicado na negociação, da mesma forma que também - e necessariamente - compreender as circunstâncias que transcendem os sujeitos, contextos e objetos das "negociações". (OLIVEIRA, 2014, p. 232).

Nesse processo de negociação cultural, em que não há vencidos ou vencedores, mas apropriação, importa

[...] compreender o que representamos como conflito, pois concebendo-o prematura e abstratamente como algo perigoso e ruim, ao procurar escondê-lo ou evitá-lo, estamos empobrecendo ou impossibilitando negociações nem sempre fáceis, mas próprias aos processos de significação [e apropriação]. (OLIVEIRA, p. 106, 2014).

González de Gómez (2002, p. 32) diz que a informação pode ser concebida como uma "dimensão das práticas e interações dos indivíduos, situados no mundo junto com outros indivíduos". Nesse raciocínio, estrutura, organização e conteúdo de uma unidade informacional, por exemplo, nos remete aos mediadores culturais que a produzem e organizam, bem como a seus contextos e cultura, em relações dinâmicas. 
Também de relevância para esta tese é a afirmação de Unger e Freire (2006, p. 12), quando ressaltam que "a dominação sobre a informação por determinados grupos - e como se dá esta dominação sobre raça e classes sociais - deve ser estudada para sabermos como melhorar [transformar] estas relações".

Dessa forma, o mediador cultural se depara, no desenvolvimento de mediações interculturais (ou entreculturais) com convenções e normas que ordenam a ação de indivíduos, grupos e coletividades - o Direito. Essas convenções e normas são as que cada sociedade se baseia, fundadas em usos, costumes e naquilo que entende como cultural.

Após a segunda guerra mundial é retomado um movimento internacional direcionado ao desenvolvimento dos indivíduos, tendo como marco histórico-políticoeconômico a carta de princípios que é a Declaração Universal dos Direitos Humanos (1947), trazendo mudanças nas relações internacionais e intencionando elevar a noção de cooperação em relação a de disputa entre as nações, originando organizações como a Organização das Nações Unidas (ONU) (ANNONI, 2008).

Annoni (2008) estabelece quatro pilares como estruturadores dos princípios de direitos humanos: liberdade e dignidade da pessoa humana; inter-relação social; direitos políticos e de participação; direitos econômicos, sociais e culturais. Esses pilares, segundo a autora, estabeleceram-se como norma imperativa de direito internacional e como modelo nas reformas jurídicas dos Estados ocidentais.

$\mathrm{Na}$ contemporaneidade, embora as formas de geração, circulação e consumo de informação, conteúdos e bens culturais tenham sofrido mutações diante das potencialidades técnicas, interativas e relacionais estabelecidas com a internet, por exemplo, permanece a observação da Declaração Universal dos Direitos Humanos sobre o conteúdo informacional e cultural, bem como a expressão e comunicação:

Artigo 19 - Todo ser humano tem direito à liberdade de opinião e expressão, este direito inclui a liberdade de, sem interferência, ter opiniões e de procurar, receber e transmitir informações e ideias por quaisquer meios e independentemente de fronteiras.

[...]

Artigo 27 - 1) Todo ser humano tem direito de participar livremente da vida cultural da comunidade, de fruir as artes e de participar do processo científico e de seus benefícios. 2) Todo ser humano tem direito à proteção dos interesses morais e materiais decorrentes de qualquer produção científica, literária ou artística da qual seja autor (ONU, 1947). 
É, no entanto, quanto às formas de "proteção" desses "interesses morais e materiais" que se apresentam atualmente grandes conflitos no campo da ética e do direito. Se há consideráveis mudanças nos modos de pensar, agir, sentir e se relacionar das pessoas, com o imperativo "cibercultural", como pode o direito positivo (criado pela sociedade) não atender ou ir de encontro a esses "usos e costumes" no contexto das evoluções tecnológicas que esboçam novas formas de conhecer, comunicar, expressar e representar o mundo das coisas e das ideias? Quais interesses e os de quais grupos sociais conseguem prevalecer ou irão se impor?

Para o mediador cultural, essas são questões essenciais a serem abordadas, pois colocam em discussão os contextos em que são definidos sentidos e fins culturais. Nesses contextos de conflito, ocorrem as transformações socioculturais, mas também se estabelecem (e aplicam) normas jurídicas e legislação sobre o fluxo e os processos de produção e consumo de informação e cultura, implicando, dessa forma, os processos de apropriação e protagonismo cultural.

Além dessas questões, também temos o tema da "liberdade de acesso". Rafael Capurro, que possui importante produção sobre ética da informação na $\mathrm{Cl}$, escreve que: "liberdade de acesso (freedom of access) está vinculada ao princípio democrático da igualdade de chances" (CAPURRO, 2001, p. 69). Tal observação suscita a importância, para o mediador cultural, de repensar a noção de democracia num contexto "inter" ou "entre" cultural.

Para Tourraine (1998, p. 28) a democracia precisa estar assentada numa "concepção dos direitos do homem, que funda toda uma série de direitos, tão universais quanto os do cidadão, mas que devem ser defendidos em situações sociais concretas, ou seja, face a um adversário ou a uma contraparte socialmente definida".

Touraine (1996, p. 29) define e defende a "cultura democrática" como "um esforço de combinação entre unidade e diversidade, liberdade e integração [...] a democracia é o regime em que a maioria [...] aceita que a maioria de hoje venha a se tornar minoria de amanhã".

Em relação às questões que envolvem a interculturalidade e a entreculturalidade, a expressão "contraparte socialmente definida" direciona o olhar para a complexa aplicação dos direitos ditos universais, o exercício democrático e a negociação cultural, visto que, interesses distintos e significados simbólicos precisam ser negociados entre culturas. 


\section{FORMAÇÃO EM BIBLIOTECONOMIA NO BRASIL: "humanismo" $x$ "tecnicismo"}

Elaborando um quadro da Biblioteconomia brasileira da década de 1920 à de 1980, Souza (2009) afirma que, no século XX, o Brasil ainda conhecia pouco do que a Biblioteconomia poderia oferecer para além das técnicas de descrição e localização de documento, visto que sua aplicação exige do profissional conhecimentos filosóficos, históricos, sociais e psicológicos.

$\mathrm{O}$ autor esclarece que, no início do século $\mathrm{XX}$, as bibliotecas eram praticamente inexistentes no país e que a Biblioteconomia era representada pelos profissionais da documentação e por intelectuais, também interessados na organização científica do conhecimento, que empreenderam esforço para implantar e consolidar princípios e técnicas estrangeiras. Tais contribuições, no entanto, restritas ao âmbito da Biblioteca Nacional, algumas bibliotecas estatuais e localizadas instituições. Ele registra: "Foram trabalhos para serem mais mostrados a elite do que mesmo para transformar a biblioteca em centro de educação popular" (SOUZA, 2009, p. 45).

Souza destaca que a organização que o Gabinete Português de Leitura do Rio de Janeiro fez em seus catálogos serviu de modelo para outros gabinetes, consolidando assim o uso das técnicas já praticadas no exterior e permanecendo coerente com a tradição portuguesa do século XIX: "Desse modo o século 20 iniciou-se na Biblioteconomia com uma série de iniciativas visando alcançar esse objetivo [...] primeiro institui-se normas, depois adquire-se (sic) o acervo e, por último, leva-se em conta a presença do usuário". Finalizando: "Obedecendo-se a essa seqüência de ações, chegou-se à criação do curso de Biblioteconomia na Biblioteca Nacional." (SOUZA, 2009, p. 46).

Sobre o curso da Biblioteca Nacional, o primeiro do Brasil, criado em 1911, iniciado em 1915 e extinto em 1922, Souza (2009, p. 47) observa que as disciplinas foram escolhidas por meio de uma lógica pragmática e não caracterizaram uma diretriz filosófica: "Ainda que não enfatizasse nos títulos das disciplinas, o conteúdo técnico estava embutido na disciplina Bibliografia e era de domínio empírico dos alunos.".

No entanto, ao final da década de 20 e início da de 30 do século passado, o pragmatismo de influência norte-americana foi o que prevaleceu. $E$, sob influência 
da escola norte-americana, no ano de 1929, foi implantado um curso de Biblioteconomia, com duração de um ano, no Instituto Mackenzie de São Paulo, com características "meramente técnicas" (SOUZA, 2009).

Em 1931, houve a reabertura do curso da Biblioteca Nacional, que passou a ter currículo de dois anos. No entanto, as disciplinas caracterizadas como "técnicas" não foram incorporadas naquele momento, pelo contrário, segundo Souza (2009, p. 55) "o curso estava voltado para o enriquecimento cultural", só incorporando o modelo americano em 1944.

O autor relata que, em 1936, o Departamento de Cultura da Prefeitura de São Paulo, por meio da sua Divisão de Bibliotecas, em ato administrativo, se responsabilizou pela organização do curso de Biblioteconomia a ser oferecido, anualmente, para preparar tecnicamente os bibliotecários. Porém, foi entendido que seria necessário uma escola com um curso de duração de três anos: "[...] o curso funcionou vinculado à Prefeitura apenas nos anos 1936 a 1938 [...]" (SOUZA, 2009, p.57).

Souza (2009) registra que no final da década de 1940 o Brasil já tinha cinco cursos de Biblioteconomia e, nos primeiros cinco anos da década de 1950, esse número passou para nove. No ano de 1950 foram criados os cursos de Minas Gerais, o da Universidade Federal de Pernambuco, que antes era mantido pela Prefeitura do Recife, o do Paraná e o da Universidade Santa Úrsula, em 1957.

Além desses cursos, o autor destaca a criação de eventos técnicos, especialmente o I Congresso Brasileiro de Biblioteconomia, realizado no Recife, em 1954, e depois denominado Congresso Brasileiro de Biblioteconomia e Documentação (CBBD), que, na atualidade, é denominado Congresso Brasileiro de Biblioteconomia, Documentação e Ciência da Informação (CBBD) e pode ser considerado o principal evento técnico e profissional da área.

Ainda sobre a década de 1950, Souza destaca que o conservadorismo do currículo das escolas existentes desconsiderava as necessidades e as características dos públicos: urbanos e rurais. Sendo assim, pode ser observado um currículo carente de subsídios para o estudo do público e "sua humanidade". Em 1955, foi implantado o Curso de Pesquisas Bibliográficas no Instituto Brasileiro de Bibliografia e Documentação (IBBD). Essa especialização, resultante de sugestão norte-americana, era oferecida aos profissionais formados em áreas diversas, interessados em documentação. Porém, 
[...] essa busca de rumo se mostrou em desacordo progressivo com o que os países hegemônicos viam como de interesse do Brasil [...] e a única marca de progresso foi a imposição estrangeira para se completar no país a infra-estrutura necessária à sua industrialização. (SOUZA, 2009, p. 70).

De acordo com o autor, os bibliotecários lutavam por símbolos de "identidade" profissional e conseguiram o reconhecimento da profissão em 1958, o que também impulsionou a oferta de ensino. E, no início de 1960, o país já possuía 10 cursos, passando a 19 até 1966, a maior parte deles vinculada a universidades federais. Nesse início de década, foi fixado o currículo mínimo do curso de Biblioteconomia pelo Conselho Federal de Educação (Parecer n. 326/CFE/62) e sancionada a Lei $n$. 4.084, de 30 de junho de 1962, que regulamenta o exercício profissional. Quanto ao parecer, Souza (2009, p. 87) explica que sua

[...] implantação deveria iniciar a partir de 1963. A duração do curso seria de três anos. As matérias, em número de dez, eram constituídas basicamente por aquelas do currículo importado dos Estados Unidos e implantado em 1936 no Curso do Departamento de Cultura da Prefeitura de São Paulo. A elas se acrescentavam algumas outras matérias tidas de conhecimento humanístico ao futuro bibliotecário. Essa providência era indispensável, na medida em parte dos candidatos ao Curso de Biblioteconomia seria composta por indivíduos que concluíram cursos equivalentes ao hoje Ensino Médio, em face da ampliação da população, o que mudava o perfil sociocultural e econômico dos ingressantes.

O autor observa que era dada mais atenção às matérias de caráter técnico, conferindo, assim, um perfil técnico aos bibliotecários. As matérias que receberam mais atenção, de acordo com Souza (2009), foram Catalogação e classificação, Bibliografia e referência, Documentação, Organização e Administração de bibliotecas, Paleografia, além de História do livro e das bibliotecas. As outras eram: História da literatura, História da arte, Introdução aos estudos históricos e Evolução do pensamento filosófico e científico. Mas o autor ressalta que todas eram insuficientes à formação para o trabalho de organização da informação técnica e científica demandada pelo crescimento industrial. Portanto, segundo o autor, para atender ao propósito do desenvolvimento econômico, foi implantado o curso de Mestrado em Ciência da Informação, pelo IBBD.

Nos anos 1970, o ensino de Biblioteconomia começou a sofrer mais intensamente os efeitos das mudanças impulsionadas pela disputa científica e 
tecnológica entre Estados Unidos e União Soviética. Nesse sentido, segundo Souza (2009, p. 102), o conteúdo curricular precisava seguir na direção da informação científica e tecnológica, bem como na de seus usuários. Até então, o conteúdo, era "supostamente dirigido para a biblioteca pública e/ou escolar".

No sentido da formação para o atendimento de demandas, se por um lado, quiseram priorizar uma determinada necessidade social da profissão, por outro lado, não atentaram para uma outra necessidade que seria isolada ou relegada - a necessidade social de apropriação e de protagonismo cultural.

Segundo Souza, em 1977, chegou-se a uma nova proposta de currículo mínimo, para que o curso passasse para quatros anos (eram três anos). Quanto às disciplinas, aglutinou-se o currículo vigente, de 1962, com propostas debatidas em congressos e artigos, até 1976. No entanto, para o autor, em relação à questão do ensino de graduação em Biblioteconomia, "como sempre foi escamoteada uma mudança real e concreta na biblioteconomia brasileira.". Visto que, na sua compreensão, todas as propostas partiam da premissa da "manutenção do exclusivismo profissional do bibliotecário, isto é, de um profissional definido pelas atribuições e competências postulados pela Lei n. 4.084/62." (SOUZA, 2009, p. 105). E, portanto, também formados segundo o paradigma tecnicista imanente.

Assim, para o autor, se houve um foco visível nos cursos de mestrado, os benefícios sociais foram limitados, visto que a atividade profissional é exclusividade do graduado em Biblioteconomia, conforme a legislação de 1962 e, portanto, nem todos os profissionais com o mestrado focado na "demanda social" poderiam exercer o fazer biblioteconômico.

Os esforços da década de 1970 se estabelecem de forma consensual apenas a partir da década de 1980. Precisamente no ano de 1982, quando foi aprovado um novo currículo, implantado em 1984, decorrente das discussões no âmbito da Associação Brasileira de Ensino de Biblioteconomia e Documentação (ABEBD) e proposto ao Conselho Federal de Educação. Porém, "Uma verificação do texto da resolução n. 08/82, de 29 de outubro de 1982, leva a constatação de que o relator do processo no Conselho Federal de Educação propôs modificações nas matérias componentes do currículo..." (SOUZA, 2009, p. 126). Assim, a proposta original da Associação foi desfigurada e aprovada.

Segundo o autor, a atitude do relator, apesar de sua independência dos interesses da $A B E B D$, representados no documento resultante do trabalho de mais 
de uma década dos professores de Biblioteconomia, se deve ao seu entendimento de que a proposta pouco mudaria a realidade do ensino, considerando a mudança de alguns nomes de disciplinas e pouca preparação de pessoal - "[...] o atendimento das necessidades concretas de preparação de recursos humanos capazes de atender ao desenvolvimento econômico do País, em termos de informação científica e tecnológica, ficou, de certo modo, insuficiente e confusa" (SOUZA, 2009, p. 127). Souza afirma, ainda, que também insuficiente e confusa estava a contribuição da escola na formação do bibliotecário para desempenhar funções na biblioteca pública e escolar. Mas, ponderando sobre o percurso dos esforços empreendidos para a vigência do "novo" currículo mínimo, escreve:

[...] torna-se evidente que a discussão sobre o currículo mínimo dos anos 1970, sua aprovação no começo da década de 1980, sua implantação que se dá a partir de1984, não estava encerrada. Até porque, se tudo estava em acelerada transformação história no mundo e no Brasil, não seria o Ensino de Biblioteconomia o único a ficar "congelado", mesmo porque o currículo mínimo aprovado não fora bem aquele desejado pela $A B E B D$ e, supostamente, por parte das escolas (SOUZA, 2009, p. 128).

Na década de 1990, segundo Souza (2009), o quadro biblioteconômico do país é permeado pelo discurso do "moderno profissional da informação", ecoando especialmente na produção acadêmica e, mesmo de forma não intencional, desqualificando a formação e o profissional bibliotecário:

Tal discurso focado na gestão da informação, até pela origem da FID, que tinha o seu âmbito de ação e abordagem prática direcionados à informação científica e técnica, reforça a idéia de que na escola de Biblioteconomia deve-se preparar "profissionais da informação" modernos, eficientes e competentes (SOUZA, 2009, p. 146).

Para o autor, havia uma mensagem subliminar para a extinção da carreira de bibliotecário, evidenciando os problemas de autovalorização e baixa aceitação social, em parte como resultado do que era feito na escola de Biblioteconomia. Souza (2009) afirma que o quadro biblioteconômico da década de 1990 se configura como terra de ninguém. Na sua avaliação, essa década acrescentou dificuldades para o ensino de Biblioteconomia e 
dos cursos de Biblioteconomia e dirigentes de sua Associação para extingui-lo, aceitando inserção, sem o devido esgotamento da discussão, da designação "profissional da informação", levando a uma possibilidade muito forte, sem que se articulem os argumentos em torno da leitura, conteúdos escolares, conhecimento público, social e estético, de prevalecer a formação para os trabalhos da ICT, e não se capacitarem bibliotecários para as áreas publica e escolar (SOUZA, 2009, p. 149).

Como registra Laura Russo (1966), até a Resolução do Conselho Federal de Educação, de 4 de dezembro 1962, não havia um currículo mínimo obrigatório para as escolas de Biblioteconomia. No entanto, segundo a autora, muitas escolas ficaram insatisfeitas com o resultado, pois consideravam que se estabeleceu um excessivo número de "disciplinas culturais" para uma formação que deveria ser técnica, embora a comissão nomeada pelo Conselho para elaborar o estudo desse currículo mínimo tivesse enfatizado a necessidade de melhor formação cultural do bibliotecário. Segundo Lauro Russo (1966, p. 20):

Algumas escolas ministram as matérias de integração cultural nos primeiros anos do curso, outras dão preferência às técnicas, fazendo a integração cultural no seu término. Tal divergência pode criar dificuldades de assimilação do conhecimento técnico, provocando certa insegurança do recém-diplomado ao enfrentar os problemas da vida profissional. Ao nosso ver, em alguns casos, falta melhor entrosamento das matérias para que sejam abolidas as dificuldades.

Laura Russo (1966, p. 23-24) descreve na obra "Biblioteconomia Brasileira: 1915/1965" que o currículo mínimo de Biblioteconomia, apresentado pela comissão designada pela diretoria de ensino superior e homologado em 1962, expõe na "justificação" a problemática do eruditismo versus tecnicismo. O documento afirma que, após cinquenta anos de existência, o ensino de Biblioteconomia estava em crise:

O ensino de Biblioteconomia deixou de ser eminentemente erudito para tornar-se, no decorrer dos anos, exclusivamente técnico [...] Em 'MISION DEL BIBLIOTECARIO', Ortega y Gasset analisou magistralmente este problema, propondo uma função mais elevada para o Bibliotecário; a de intermediário entre o mundo dos leitores e o mundo dos livros [...] Vê-se claramente que, na formação do bibliotecário, as disciplinas culturais são tão instrumentais quanto às técnicas [...]. 
Nesse sentido, estava em risco a contextualização e a articulação da técnica com o sociocultural e o político, prevalecendo, contudo, na prática, a compreensão redutora da profissão como conjunto de procedimentos técnicos. Lembrando que o problema não é a técnica, mas o tecnicismo, a tendência a reduzir tudo à técnica de forma acrítica. Com isso, temos o desenvolvimento de uma visão procedimental no bibliotecário e não uma atitude em relação à informação que associe procedimentos às finalidades históricas e sociais.

Ao discutir a trajetória escolar do ensino da Biblioteconomia no Brasil, Castro (2000) afirma as diferenças do ensino do curso da Biblioteca Nacional, no Rio de Janeiro (iniciado em 1915), e o da Escola Livre de Sociologia e Política, em São Paulo (1940). O ensino da Biblioteca Nacional era marcado pela influência humanística da francesa École des Chartes, segundo o autor, enquanto o ensino da Escola Livre de Sociologia e Política, era essencialmente técnico, influenciado pela estadunidense Columbia University. Castro (2000, p. 101) esclarece que "[...] nos E.U.A, a idéia predominante era a de que os alunos ao entrarem numa Escola de Biblioteconomia traziam conhecimentos culturais suficientes, cabendo a estas fornece-lhe as técnicas [...]".

A expansão do ensino de Biblioteconomia nas várias regiões do país, segundo Castro (2000), foi fenômeno positivo, mas também trouxe problemas como o "transplante" acrítico dos currículos de Rio de Janeiro e São Paulo. Embora no decorrer dos anos tenham havido várias transformações nos perfis dos bibliotecários na direção do "ideal profissional”, com o espaço universitário da Biblioteconomia e o reconhecimento legal da profissão, segundo o autor, "em torno dessas duas questões" centralizavam-se os debates dos bibliotecários (e da formação), até o início dos anos 60". Para Castro (2000, p. 118), na procura por valorização e status profissional a categoria:

[...] busca se enquadrar, às vezes, de modo abrupto e desconectado da realidade nacional, aos modismos paradigmáticos de outras ciências sociais [...] parece haver nestes 'novos discursos' um desconhecimento dos problemas sociais, que geram marginais e corruptos; educacionais, que não conseguem eliminar 0 analfabetismo tecnológico das letras, agora agravado pelo analfabetismo tecnológico e cultural, que não consegue romper com os preconceitos, historicamente construídos, sobre o negro, a mulher e outras minorias sociais [...]. 
Castro (2000, p. 266) observa que quando o Brasil adotou o "modelo humanista" francês, tal modelo já era considerado obsoleto e criticado pelos bibliotecários "progressistas" da França. Assim, o ensino de Biblioteconomia no Brasil já teria nascido ultrapassado. Por outro lado, a adoção do "modelo tecnicista" americano fez com que o aspecto cultural da profissão fosse abandonado:

Isto em termos práticos, posto que nos discursos não há esta dicotomia entre os dois modelos, inclusive entre os bibliotecários que estabeleceram e divulgaram o pragmatismo na Biblioteconomia: Rubens Borba de Moraes, Adelpha de Figueiredo e Laura Russo, dentre muitos outros.

No entanto, esclarece:

Isto não significa, entretanto, que o modelo europeu, como se pensava, fosse somente contemplação do acervo e da biblioteca, mas as técnicas (catalogação e classificação) eram conteúdo da disciplina Bibliografia. A diferença entre ambos os modelos é que um privilegiava uma formação mais erudita do bibliotecário e o outro uma formação mais técnica.

Nas últimas décadas do século XX podemos identificar também o discurso do "moderno profissional da informação" no lugar do Bibliotecário. Questão posta na demanda social da inclusão digital, junto ao crescente desenvolvimento das tecnologias digitais, pois era preciso concretizar a "Sociedade da Informação".

Neste contexto, segundo Dudziak (2001), foi preciso admitir que era necessário inovar os sistemas e desenvolver habilidades para o uso eficiente e eficaz da informação, além das ferramentas que servissem para seu acesso e para resolução de problemas. Isso tudo foi reunido na expressão information iiteracy que, segundo a autora, apareceu na literatura pela primeira vez em 1974, num relatório do presidente da Information Industry Associaton (IIA), o bibliotecário americano Paul Zurkowski. "A informação era entendida naquele momento como um produto a ser consumido" (DUDZIAK, 2001, p. 54).

No Brasil, Campello, em 2002, traduz a expressão information literacy por "competência informacional" e explica que a tradução se deu "na perspectiva da biblioteca escolar, em texto que sinalizava para o potencial desse conceito como catalisador das mudanças do papel da biblioteca em face das exigências da educação no século XXI." (CAMPELLO, 2003, p. 29). Segundo ela: 
Havia, na época, entendimento de que as mudanças, especialmente aquelas relacionadas à tecnologia da informação, iriam influenciar fortemente o trabalho do bibliotecário. Tornavam-se freqüentes os questionamentos a respeito da função do bibliotecário e da biblioteca nesse ambiente mutante e com novas perspectivas para a educação. (CAMPELLO, 2003, p. 30).

A partir de então, do profissional de Biblioteconomia era exigido perfil que fosse compatível com as mudanças e incrementos de papéis e tarefas para atender tanto a um público já consumidor de informação e cultura quanto a outros ainda não inclusos. De acordo com a Declaração de princípios da Cúpula Mundial da Sociedade da Informação (CMSI) - Genebra 2003 e Túnis 2005:

Los creadores, editores y productores de contenido, así como los profesores, instructores, archivistas, bibliotecarios y estudiantes deben desempeñar una función activa em la promoción de La Sociedad de La Información, particularmente em los países menos adelantados (CÚPULA MUNDIAL DA SOCIEDADE DA INFORMAÇÃO, 2004).

Se essa era a necessidade social da profissão - promover a "sociedade da informação" -, como é possível, mesmo que tal necessidade social seja discutível, atuar em benefício da inclusão social e digital e do letramento digital dos indivíduos e das coletividades (o que para a Biblioteconomia significava transcender o que se havia convencionado como "educação do usuário"), sem considerar a complexidade, os conflitos, os interesses culturais e políticos no campo da informação?

Por letramento digital, podemos entender, conforme Soares (2002, p. 151): "um certo estado ou condição que adquirem os que se apropriam da nova tecnologia digital e exercem práticas de leitura e de escrita na tela, diferente do estado ou condição - do letramento - dos que exercem práticas de leitura e de escrita no papel.". Em todo caso, a incorporação dessas práticas deve induzir, habilitar, dar opção ao indivíduo de inferir e interferir na sociedade ativa e afirmativamente, compondo um quadro de inclusão, de apropriação e de protagonismo cultural.

Sendo assim, as expectativas eram de que o profissional bibliotecário estivesse capacitado e habilitado para o trabalho de letramento digital voltado à inclusão na "sociedade da informação"? Pois este sendo também um estado adquirido de prática da leitura, tornava-se explícito (mas não só por essa razão) que uma das instituições "naturalmente" responsáveis por ações de inclusão social e 
digital seria as bibliotecas pública e escolar. E não só disponibilizando máquinas e conexão à internet, mas propiciando, desenvolvendo e ampliando o letramento digital e desenvolvendo a "mediação de leitura".

Neste contexto, competiria ao bibliotecário desenvolver práticas de mediação da informação, além do acesso aos variados suportes de informação. Tornava-se vital acompanhar as transformações estruturais nas formas de acessar e adquirir informação e conhecimento, especialmente as emergentes, como também compreender a mudança de paradigma de utilização da biblioteca. Quais, todavia, seriam as ferramentas cognitivas oferecidas pela formação, compreendendo o bibliotecário como um mediador cultural?

A não compreensão da categoria mediação cultural como elemento intrínseco da profissão de bibliotecário e, portanto, da formação, pode ser considerada um agravante da crise de identidade e baixa autoestima que o profissional enfrenta no Brasil, situação para a qual contribuiu os descaminhos trilhados pelas Escolas de Biblioteconomia (SOUZA, 2009; CASTRO, 2000).

Este capítulo foi elaborado no sentido de entendermos como, no Brasil, se desenvolveu a problemática formação em Biblioteconomia no século XX. Interessanos, igualmente, observar a questão experimentada na França para também discutirmos um movimento de confluência, o qual defendemos, da formação no sentido da mediação cultural. 


\section{FORMAÇÃO EM BIBLIOTECONOMIA NA FRANÇA : o "erro" epistemológico}

Propondo um olhar retrospectivo e prospectivo sobre a formação profissional dos bibliotecários, Renoult (2009) afirma que, durante séculos, na França, a guarda e a organização das coleções dos livros das bibliotecas foi confiada aos cientistas, aos eruditos, aos "homens de letras".

No entanto, o século XIX e o século XX são caracterizados pelo surgimento de um conhecimento profissional autônomo da erudição, juntamente à institucionalização de diplomas profissionais. Segundo Renoult (2009, p. 64): "Na França, normalmente se associa o início da formação profissional à École Nationale des Chartes (1821) e à criação, em 1879, de um primeiro certificado de aptidão para as funções de bibliotecário.".

Como afirma Renoult (2009), as formações de bibliotecários na Europa foram desenvolvidas, especialmente, no século XX. No caso da França, é nesse período que se estabeleceram, progressivamente, diferentes diplomas para certificar uma formação inicial. Segundo o autor, os mais significativos são o diploma técnico de bibliotecário, em 1932, o diploma superior de bibliotecário, em 1950, e o certificado de aptidão as funções de bibliotecário (CAFB), em 1951. O autor observa que é desse período a criação de escolas que existem, hoje, na França:

Observamos ainda neste movimento de emancipação progressiva da formação profissional de bibliotecários na Europa, o estabelecimento de escolas especializadas, na Alemanha, a partir de 1914 e, na França, alguns anos mais tarde, a criação de muitas escolas das quais várias ainda existem hoje: em Paris, logo em 1923, a Escola de bibliotecários na rua de L'Elysée; em seguida, em 1930, a Escola municipal de bibliotecários; em 1935, a Escola de bibliotecários documentalistas do Instituto Católico; em 1950, o Instituto Nacional de documentação, técnicas INTD; finalmente, em 1963-1964, a Escola Nacional Superior de Bibliotecários (ENSB), que se tornará o Enssib, em 1992. (RENOULT, 2009, p. 64, tradução nossa).

Para Renoult (2009), havia uma preocupação de que a responsabilidade e os acervos de instituições específicas fossem assumidos por bibliotecários com formação estruturada e liberta de pesquisa erudita e histórica, anexada a essas formações até então. Dessa forma, "A partir de 1932, a Escola de Chartes foi responsável pela preparação para o diploma de bibliotecário, mas alguns anos mais tarde, a partir de 1947 e sob a liderança de bibliotecários de Chartes, como Louise- 
Noëlle Malclès, a formação dos bibliotecários será gradualmente separada." (RENOULT, 2009, p. 64). O autor ainda observa que:

Nessa época, essa ruptura é considerada essencial numa visão mais ampla da missão das bibliotecas públicas e em particular para desenvolver as funções de "leitura pública" em comparação com as missões de estudo e pesquisa. No entanto, esta emancipação da formação profissional dos bibliotecários e este isolamento relativo das instituições de ensino superior terão consequências sobre o conceito mesmo das formações, e depois sobre as relações com universidades. (RENOULT, 2009, p. 64, tradução nossa).

Por isso, ele afirma que, por vários anos, a formação profissional, bem como a preparação para os concursos, foram atribuições de profissionais já incorporados na estrutura das instituições:

\begin{abstract}
Assim, durante anos, a formação profissional com diploma, e também a preparação para os concursos foram assumidos por completo por profissionais dentro das estruturas pertencentes à corporação. Este projeto ainda prevalece para a formação de base, fornecida pelas bibliotecas departamentais de empréstimos (DBM, ex - BCP), ou pela Associação dos bibliotecários da França, e ele se aplicou também nos outros níveis de formações até nas póslicenciatura, na ENSB como no INTD ou na Escola de bibliotecários documentalistas do Instituto Católico. Esta orientação é ainda evidente em publicações, utilizadas para a formação de bibliotecários. Assim, observamos que o catálogo da coleção 'Bibliotecas' publicado pelo Círculo da Livraria, que tem manuais práticos e obras de reflexão, inclui muito poucos autores nãobibliotecários. (RENOULT, 2009, p. 64, tradução nossa).
\end{abstract}

Renoult (2009) evidencia que o controle das formações é feito, sobretudo, por meio dos concursos compostos de jurados que eram, ao mesmo tempo, formadores e prescritores, afirmando que: "Decisivamente, o sistema dos concursos estrutura o âmbito da formação inicial. Qualquer tentativa de diversificação de conteúdos e práticas encontra seus limites no programa e na natureza das provas." (RENOULT, 2009, p. 64, tradução nossa).

Para o autor, essa formação realizada pelos pares tem vantagens, pois complementa outras formações acadêmicas, é feita numa relação com empregadores e combina acompanhamento individual à integração para o emprego que, segundo ele, é uma questão que a universidade francesa só avaliou recentemente. 
No entanto, Renoult (2009) aponta também as desvantagens, como o fato de as técnicas chegarem a se sobrepor à metodologia, ao ponto de estruturarem a identidade profissional; a segmentação dos funcionários e "rigidez" das funções nas bibliotecas públicas; o risco da reprodução de técnicas sem a reflexão crítica necessária à inovação; a irregular quantidade e qualidade de profissionais na condição de professores.

Essas dificuldades indicavam, segundo o autor, a necessidade de aproximar a formação de bibliotecários das universidades. Nesse sentido, em 1987, o Ministério do Ensino Superior e o Ministério da Cultura e da Comunicação, lançaram uma licitação visando reforçar a qualidade educacional dos centros de formação. Assim, em 1992, "[...] o estatuto da Escola Nacional de Ciências da Informação e das Bibliotecas conferiu a esta escola o status universitário de grande instituição [...]". Renoult (2009, p. 65), ressalta que o ensino superior coincidiu com o surgimento da Ciência da Informação, mas pondera:

Com mais de quinze anos de retrospectiva, podemos estimar que esta aproximação com esta disciplina não reforçou realmente as formações profissionais. $O$ desenvolvimento excepcional das industrias da informação durante alguns anos nutriu muitas esperanças e algumas ilusões. Vimos notadamente se instalar uma certa confusão entre a tecnologia da informação e a informação, entre as técnicas e os usos da informação. Mas, além dos malentendidos causados pela preferência concedida as ciências da informação e as consequências em termos de distribuição de emprego de professores pesquisadores, deve ser observado um pesado erro epistemológico de identificação que é de identificar um domínio, as bibliotecas, com uma disciplina, seja ciências da informação ou história. (RENOULT, 2009, p. 65, tradução nossa).

Renoult (2009) constata que houve, de fato, poucas reflexões sobre as consequências de integrar a formação dos bibliotecários às universidades, configurando um "erro epistemológico", no caso da França. Conforme o autor, as universidades são organizadas por disciplinas ("Ciência da Informação ou História"), mas o "domínio" biblioteca demanda diferentes saberes e fazeres que são procedentes de múltiplos campos do conhecimento, além da própria prática profissional:

É evidente que existem poucas reflexões anteriores sobre os problemas científicos colocados pela integração da formação dos 
bibliotecários (que trata de instituições, de públicos, de técnicas e de especializações, não abrangidas por um único domínio disciplinar) em universidades organizadas principalmente por disciplinas. (RENOULT, 2009, p. 65, tradução nossa).

Além disso, outra questão se coloca com a eminente diversificação das competências e das funções nas bibliotecas:

[...] a apropriação dos campos profissionais por disciplinas acadêmicas é ainda mais complexa porque ela surge em um momento em que se coloca aos empregos de bibliotecas um problema de identidade, devido a uma extraordinária diversificação das competências e das funções. (RENOULT, 2009, p. 65, tradução nossa).

De acordo com Bettant (2012, p.32), a formação dos bibliotecários avançou em vários países europeus na mesma época - em torno da década de 1950. Nesse período, a autora destaca do relatório da quinta sessão da XVII Conferência do FID, realizada em Roma em abril de 1950, que havia na França muitas bibliotecas e uma quantidade insuficiente de bibliotecários, gerando, assim, a necessidade de elevar o nível do ensino superior do bibliotecário e também persuadir as autoridades competentes a colocarem nas bibliotecas quantidade suficiente de funcionários bem remunerados.

Bettant afirma, ainda, que os anos de 1930 a 1950 demandaram significativas mudanças na formação, à medida que o já estabelecido Diploma Técnico de Bibliotecário (DTB) estava enfraquecido e não se distanciava da École des Chartes, esta considerada no relatório da quinta sessão da XVII Conferência do FID como ultrapassada:

[...] os pedidos de separação entre a formação dos bibliotecários e a École des Chartes, o aumento do nível de acesso para o diploma superior e a formação dos profissionais das bibliotecas do piso inferior foram finalmente feitas no início dos anos 50, com a criação de novos diplomas. A reorganização da profissão poderia se realizar e o Estado seria responsável pelas bibliotecas menores. (BETTANT, 2012, p. 33, tradução nossa).

Continuando, Bettant observa que, mesmo tendo sido elevada a quantidade de diplomados (Diploma Superior de Bibliotecários (DSB)) - entre 1951 e 1963 - 366 graduados, sendo 15 estrangeiros, numa média de 26 por ano -, a quantia era insuficiente para atender as necessidades. A autora analisa que: 
Com a criação de uma escola, de acordo com o relatório, o retorno dos estudos, o prestígio de uma grande escola, a quase certeza de se tornar bibliotecário titular atrairia os candidatos. De fato, um exame técnico, um ano de estudo puxado e, em seguida, um concurso muito aleatório não incentivavam as vocações [...] com a escola, a bancada de jurados seria mais propensa à indulgência, sabendo que dois anos de estudo, com os exames e estágios, iriam dar experiência para os alunos. Um concurso de admissão teria a vantagem, de acordo com o relatório, de remover a alta evasão, que anualmente se elevava a um terço dos efetivos do DSB. A propaganda do concurso foi feita pela senhorita Salvan que fez imprimir e colocar aproximadamente 600 cartazes em faculdades, prefeituras, grandes escolas e organizações de orientações para que houvesse candidatos para o primeiro concurso da [École Nationale Supérieure des Bibliothèques] ENSB. O último relatório da DSB conclui assim: "É óbvio que, de ano em ano, cada vez mais alunos se interessarão pelo ENSB que aparecera para muitos alunos de licenciatura como a escola de aplicação mais provável para dar um real valor a seus estudos universitários e assegurará para eles uma carreira que os afastara menos da universidade". (BETTANT, 2012, p. 45-46, tradução nossa).

A École Nationale Supérieure des Bibliothèques, criada em julho de 1963, segundo Bettant (2012), não teve os resultados esperados por se parecer muito com seus antecessores, mas foi um passo à frente por conseguir modernizar a formação considerando os aspectos técnicos e configurando independência do ensino da École des Chartes. Bettant (2012), explica que:

[...] entre 1932 e 1963 mostram-nos que o trabalho de bibliotecário pediu uma preparação real. Em 30 anos, podemos dizer que se tentou de tudo para dar aos novos bibliotecários formação adequada: estágios, trabalhos práticos, cursos, conferências [...] A partir dos anos 50, ninguém contestou a necessidade de uma formação técnica própria à profissão de bibliotecário. Nesta época, as tensões foram primordiais e o ENSB não foi fundada a partir do nada porque os trinta anos precedentes formaram uma terra favorável para seu nascimento. No final do nosso período, podemos dizer que a necessidade de uma qualificação real para os bibliotecários foi reconhecida. (BETTANT, 2012, p. 75, tradução nossa).

De acordo com a autora, podemos considerar que, na França, no início dos anos 60 , as várias funções nas bibliotecas tinham sua graduação e sua formação: "[...] este avanço deveu-se aos bibliotecários, que, por suas iniciativas, criaram escolas e formações [...] Todos queriam apagar a imagem do bibliotecário empoeirado, que não tinha deixado o século XIX, para substituí-lo por um homem útil à sociedade contemporânea [...]" (BETTANT, 2012, p. 75). 
Bettant (2012) afirma que Henriot é um dos que defendem o "ensinar e reensinar" mais que conservar, requisitando uma formação especial: "os bibliotecários da geração de Henriot focaram freqüentemente sua visão da profissão sobre a leitura pública e o serviço para o usuário. Todos pediram que a formação desse uma ênfase a este aspecto da relação com o público e a ajuda a sociedade [...]" (BETTANT, 2012, p. 76).

A autora também afirma que a escola americana dos anos 20 do século passado foi quem despertou a vontade nos profissionais franceses de uma escola francesa de bibliotecários. E quanto à École Nationale Supérieure des Bibliothèques, Bettant (2012, p. 76) diz que:

O projeto pedagógico não apagou o passado, em vez disso, ele retomou o que parecia ser o melhor nas formações anteriores. A multiplicação (relativa) do número de bibliotecas nos anos sessenta e os avanços científicos mostraram a necessidade de acabar com a estagnação da profissão de bibliotecário [...].

Então, esclarece Bettant, a formação se realizava da seguinte forma:

Os estudantes com uma licenciatura ou um título equivalente entravam com um concurso e se tornavam então alunos titulares da ENSB. Eles entravam por dez anos no serviço público, sistema que hoje encontramos. Aqueles que não queriam este compromisso eram alunos associados e pagavam mensalidades. Paule Salvan previa uma escolaridade de dois anos. No primeiro ano, uma formação de base completa devia ser ensinada. Um diploma de bibliotecário no final desse ano devia ser entregue, o que permitiria aos alunos associados gerir bibliotecas que não fossem controladas pela Direção das bibliotecas da França. Durante o segundo ano, havia um estágio de seis meses. Voltávamos para o estágio que tinha sido abandonado com o surgimento do DSB, em 1950, para o desgosto de muitos bibliotecários. Esse estágio de aplicação permitia candidatos iniciar uma dissertação. Os alunos então escolhiam a seção $A$ ou seção $B$. A seção $A$ era voltada para a história das bibliotecas, a história do livro e das ciências humanas enquanto a seção B tratava das ciências sociais, ciências exatas e da medicina no intuito de gerir setores especializados nas novas BU. Encontramos, portanto as duas seções $A$ e $B$ dos últimos anos do DSB. Tudo era por um diploma superior de bibliotecário-bibliógrafo. Os dois anos exigidos por muitos bibliotecários para a formação profissional pareciam finalmente adquiridos. Até então só Gabriel Henriot tinha feito a formação até dois anos na sua escola da rua d'Assas. Estes dois anos foram substituídos por um ensino geral e um ensino especializado, bem como um estágio. O melhor da preparação da DTB (o estágio) se associando ao melhor da preparação do DSB (as especializações). Em relação aos princípios 
do ensino, eles foram ditados pela necessidade de desenvolver a ajuda para o leitor. Paule Salvan indicava o ano 1950 como sendo o verdadeiro renascimento da psicologia dos bibliotecários, o que é consistente com todas as mudanças que temos por este ano. $O$ estudo material das obras e de tudo que afetavam as bibliotecas era feito só para ser comandado para o Homem, o progresso do pensamento e da sociedade [...] (BETTANT, 2012, p. 77, tradução nossa).

Portanto, a formação profissional dos bibliotecários na França, que se iniciou com a École Nationale des Chartes, em 1821, a partir dos anos de 1930 consegue se distanciar do modelo considerado conservador e enciclopedista, sobretudo pelo desejo de aproximação com o pragmatismo técnico da escola americana dos anos 20. Mas caminha em direção seja da "leitura pública" seja "para ser comandado para o Homem, o progresso do pensamento e da sociedade".

No Brasil, como vimos no capítulo anterior, o início da formação com a Biblioteca Nacional, em 1915, foi marcado pelo modelo francês da École des Chartes, mas, depois, no final da década de 1920 e início da década de 1930, pela influência do pragmatismo técnico, de origem norte-americana. Assim, verificamos que a formação do bibliotecário no Brasil, e também na França, país que primeiro influenciou essa formação, se deu, e vem evoluindo, na tensão entre cultura e técnica, humanismo e tecnicismo, saberes teóricos e práticos, saber pensar e saber fazer. As mudanças de nível e status (técnico/universitário) não teriam ainda conseguido solucionar os conflitos históricos entre as direções que se opõem, mas que se complementam e completam.

Nesse sentido, a observação de Renoult, já mencionada, é preciosa, pois aponta para uma dificuldade que nasce das lógicas inerentes ao fenômeno tratado: "[...] deve ser observado um pesado erro epistemológico de identificação que é de identificar um domínio, as bibliotecas, com uma disciplina, seja ciências da informação ou história." (RENOULT, 2009, p. 65).

A observação de Renoult, nesses termos, retoma as de Souza (2009), ao criticar, como vimos páginas atrás, o discurso do "moderno profissional da informação" que desqualificaria a formação e o profissional bibliotecário.

Como os discursos de diversos documentos orientadores da formação descrevem o bibliotecário é o que veremos na pesquisa. Tais documentos, em que pese as diferenças entre eles, definem, dão parâmetros, normas, fixam critérios, 
prescrevem, constroem representações ou produzem práticas formativas que necessitam ser analisadas. De que forma eles contribuem para a superação dos impasses e de que forma os aprofundam, iremos examinar. 


\title{
PARTE 2: CAMINHO METODOLÓGICO
}

\section{ACERCA DA METODOLOGIA}

Numa proposta de pesquisa, o investigador evidencia suas motivações e objetivos diante da abordagem de uma questão ou problema que precisa ser identificado e caracterizado, mas também, segundo Creswell (2007, p. 35), faz "alegações de conhecimento", pois "[...] pesquisadores começam um projeto com determinadas suposições sobre como vão aprender e o que vão aprender durante a investigação".

Creswell (2007) explica que essas alegações de conhecimento podem ser consideradas paradigmas, suposições epistemológicas ou mesmo metodologia de pesquisa. $\mathrm{O}$ autor também afirma que uma técnica de pesquisa qualitativa

\begin{abstract}
[...] é aquela em que o investigador sempre faz alegações de conhecimento com base principalmente ou em perspectivas construtivistas (ou seja, significados múltiplos das experiências individuais, significados social e historicamente construídos, com objetivo de desenvolver uma teoria ou um padrão) ou em perspectivas reivindicatórias participatórias (ou seja, políticas, orientadas para a questão, ou colaborativas, orientadas para a mudança) ou em ambas. (CRESWELL, 2007, p. 35).
\end{abstract}

Sendo assim, situamos esta proposta de investigação num projeto interpretativo - investigação qualitativa -, comprometido tanto com uma perspectiva compreensiva, como construtivista, na medida em que entendemos ser possível fazer algo, colaborar, ao interrogar a formação do Bibliotecário como mediador cultural, no país, em relação às questões de mediação cultural que the dizem diretamente respeito -, por meio do diálogo que será gerado pelos resultados da discussão/produção teórica.

Além disso, segundo Umberto Eco (2010), um trabalho científico pode também ser considerado político e tem valor político-positivo quando dá uma contribuição para o desenvolvimento do conhecimento geral: "Naturalmente, a 
importância científica se mede pelo grau de indispensabilidade que a contribuição estabelece" (ECO, 2010, p. 22).

Um trabalho original, segundo ele, pode estar inclusive na:

[...] reorganização e releitura de estudos precedentes que conduzem à maturação e sistematização das idéias que se encontravam dispersas em outros textos. Em qualquer caso, o estudioso deve produzir um trabalho que, teoricamente, os outros estudiosos do ramo não deveriam ignorar, porquanto diz algo de novo sobre 0 assunto (ECO, 2010, p. 2).

A cientificidade de uma tese, explica esse autor, responde a quatro requisitos - o objeto do estudo é reconhecível pelos outros; o estudo diz do objeto algo ainda não dito ou revê sob visão diferente o que já se disse; o estudo é útil aos demais; o estudo fornece elementos para a verificação ou contestação das hipóteses "e, portanto, para uma continuidade pública" (ECO, 2010, p. 23).

Neste trabalho, desenvolvemos pesquisa bibliográfica no sentido de compreender e aprofundar questões em torno da mediação cultural e da formação de bibliotecários no país. Para tanto, foi realizado estudo, com recorte do século XX, sobre a formação de bibliotecários no Brasil e na França. Por outro lado, foi realizada pesquisa documental em documentos orientadores que servem como diretrizes para a formação do bibliotecário, bem como análise da apresentação de propostas de cursos de mediação cultural, por descreverem o mediador cultural, também no Brasil e na França.

O objetivo geral foi interrogar a formação do bibliotecário como mediador cultural no país. Especificamente, investigamos as relações entre a mediação cultural e a formação de bibliotecários e buscamos apontar, evidentemente, perspectivas de superação de desafios para a formação do bibliotecário como mediador cultural, comprometido com processos de apropriação e de protagonismo cultural.

O estudo da literatura sobre a formação do bibliotecário, no Brasil e na França, não consistiu numa "história da formação", nem na realização de um "estado da arte" da literatura. Tratou-se de compreender diferentes direções tomadas pela formação, seja no sentido do bibliotecário "controlador", "difusor" ou "mediador" cultural. 
A formação na França foi escolhida por dois motivos: porque a formação em Biblioteconomia no Brasil tem, em sua criação, as bases referenciadas no modelo francês de formação de bibliotecários da École des Chartes, embora depois se distancie dele. Portanto, pareceu-nos importante visualizar os rumos que tomaram as formações nos dois países no século XX; por outro lado, identificamos que, na atualidade, a França possui expertise de formação em mediação cultural.

Da mesma forma, identificamos iniciativas brasileiras significativas que nos permitiram refletir e compreender o "mediador cultural" que está sendo pensado, bem como as direções teóricas e metodológicas que estão sendo apontadas para tais formações no Brasil.

A análise documental, a partir de seleção de documentos orientadores e normativos sobre a formação de bibliotecários, permitiu a elaboração de interrogações à medida que visualizamos nos documentos categorias que apontam para sua representação seja como a de um controlador ou um difusor de acervos, seja de mediador vinculado à apropriação e ao protagonismo cultural.

Duas unidades de análise compuseram o corpus da pesquisa. Uma foi constituída por manifestos da International Federation of Library Associations and Institutions (IFLA) e Organização das Nações Unidas para a Educação, a Ciência e a Cultura (UNESCO), além da lei brasileira que regulamenta a profissão de bibliotecário e diretrizes do Ministério da Educação (MEC). A outra unidade de análise são as apresentações de propostas de cursos de mediação cultural, da França e do Brasil: dois cursos de pós-graduação e um de graduação, na França; e dois cursos de pós-graduação e um de graduação, no Brasil.

- Na França: Mestrado em Mediação Cultural, Patrimônio e Digital Universidade de Paris Ouest, Nanterre La Défense, e Universidade de Paris 8, Vincennes Saint-Denis; Mestrado em Mediações da Cultura e dos Patrimônios, Université d'Avignon; Licenciatura de Mediação Cultural: concepção e implementação de projetos culturais, Université Sourbonne Nouvelle - Paris 3.

- No Brasil: Especialização em Mediação em Arte, Cultura e Educação Escola Guignard, Universidade Estadual de Minas Gerais (UEMG); Especialização em Mediação Cultural, UFPE; Bacharelado em Letras - Artes e Mediação Cultural, Universidade da Integração Latino-americana (UNILA). 
O critério para a seleção dos cursos foi a existência da expressão "mediação cultural" ou "mediação em cultura" em sua nomenclatura. Da França, como visto, foram escolhidos dois cursos de mestrado e, do Brasil, dois cursos de especialização, já que mestrados com a expressão não foram identificados. Cada apresentação das propostas foi obtida nos sites das respectivas universidades e analisada para inferências e interpretações. Nesse sentido, também foram construídos dois quadros contendo a descrição dos cursos por meio de três categorias: apresentação, competências e atuação.

A análise dos documentos orientadores permitiu que fossem realizadas inferências, interpretação e, por conseguinte, as interrogações e verificação da nossa hipótese. A representação de bibliotecário foi procurada nas "descrições" dos profissionais contidas nos documentos que servem como diretrizes para a sua formação. Selecionamos, analisamos e interpretamos trechos que caracterizam o bibliotecário ao descrevê-lo como profissional, bem como suas competências. Além disso, a análise das propostas de cursos em mediação cultural, no Brasil e na França, serviu para embasar a ideia de "bibliotecário mediador cultural", já que das propostas foram inferidas descrições de mediador cultural.

O exame indicado forneceu condições para se interrogar e discutir a formação do bibliotecário como mediador cultural e refletir até que ponto estamos diante de um campo novo e diferenciado, que exige formação específica e especializada; até que ponto estamos diante de aspecto essencial da profissão, a ser efetivamente agregada às formações existentes, dentre outras questões. 


\section{O BIBLIOTECÁRIO COMO MEDIADOR CULTURAL: pautas para a formação}

Neste capítulo, analisaremos documentos que vem pautando a formação do bibliotecário no país, além de tratarmos também da formação de bibliotecários na França, bem como de formações de mediadores culturais, entre nós e, também, na França. Tal análise mostra-se fundamental, na medida em que o corpus examinado não só sintetiza como fornece referências que moldam, indicam, prescrevem práticas e estão na base de representações e de processos de formação profissional no campo que nos interessa nesta tese.

Analisamos, portanto, normas, diretrizes e orientações elaboradas a partir do século XX e que fornecem caracterizações do bibliotecário no país e suas competências e habilidades, fornecendo matrizes conceituais e práticas para a sua formação, bem como, em alguns documentos, para as bibliotecas, onde eles deverão atuar. Tal análise permite a elaboração de interrogações na medida em que visualizamos nos documentos categorias que colocam o profissional como "conservador", "técnico-difusor" ou "mediador cultural". Mas também permite que tenhamos a compreensão da insuficiência dos documentos quanto à definição do "bibliotecário mediador", a confusão conceitual aí existente, contribuindo pouco para a superação da dicotomia "humanismo" x "tecnicismo".

Analisamos, também, as propostas de dois cursos de mestrado e um de graduação na França, além de dois cursos de especialização e um de graduação, no Brasil, para inferências sobre o mediador cultural - como ele é descrito nas propostas, bem como suas competências e atuação, tendo em vista que o uso da expressão "mediação cultural" na nomenclatura dos cursos pode indicar "[...] tentativa de conhecer e de compreender diferentes formas de difusão da cultura e os fins aos quais respondem e pensar programas que permitem aos futuros profissionais da cultura dispor de saber e referências necessárias." (DUFRÊNE; GELLEREAU, 2004aa). 


\subsection{Normas, diretrizes e orientações para a biblioteca e para a formação do bibliotecário}

Visando o alcance dos objetivos desta tese, selecionamos documentos que podem "revelar" um tipo de profissional bibliotecário implícito. O quadro abaixo distingue esses documentos, sua natureza, bem como os objetivos de cada documento a ser analisado.

Quadro 1: Normas, diretrizes e orientações

\begin{tabular}{|c|c|c|c|}
\hline Documento & Ano & Natureza & Objetivo \\
\hline Lei no 4.084/1962. & 1962 & Norma/Lei & $\begin{array}{l}\text { Dispor sobre a profissão de bibliotecário e } \\
\text { regular seu exercício. }\end{array}$ \\
\hline $\begin{array}{l}\text { Diretrizes } \\
\text { curriculares para } \\
\text { os cursos de } \\
\text { Biblioteconomia - } \\
\text { Parecer } n^{\circ} \\
492 / 2001\end{array}$ & 2001 & Norma/Diretriz & $\begin{array}{l}\text { Tratar de diversos processos acerca das } \\
\text { Diretrizes Curriculares Nacionais dos cursos } \\
\text { de Filosofia, História, Geografia, Serviço } \\
\text { Social, Comunicação Social, Ciências } \\
\text { Sociais, Letras, Biblioteconomia, } \\
\text { Arquivologia e Museologia remetidas pela } \\
\text { SESu/MEC para apreciação da CES/CNE. }\end{array}$ \\
\hline $\begin{array}{l}\text { Manifesto da } \\
\text { IFLA/UNESCO } \\
\text { sobre bibliotecas } \\
\text { públicas }\end{array}$ & 1994 & Orientação/Diretriz & $\begin{array}{l}\text { Encorajar as autoridades nacionais e locais a } \\
\text { apoiar ativamente e a comprometerem-se no } \\
\text { desenvolvimento das bibliotecas públicas; } \\
\text { Conclamar todos em todo o mundo, a nível } \\
\text { nacional e local, que tem poder de decisão e } \\
\text { a comunidade de bibliotecários em geral a } \\
\text { implementar os princípios expressos no } \\
\text { Manifesto. }\end{array}$ \\
\hline $\begin{array}{l}\text { Manifesto } \\
\text { IFLA/UNESCO da } \\
\text { biblioteca escolar }\end{array}$ & 1999 & Orientação/Diretriz & $\begin{array}{l}\text { Conclamar os governantes de cada país } \\
\text { para desenvolver estratégias, políticas e } \\
\text { planos de implementação aos princípios do } \\
\text { Manifesto, bem como a intensa divulgação } \\
\text { do Manifesto, tanto em programas de } \\
\text { formação básica como de educação contínua } \\
\text { a bibliotecários e professores. }\end{array}$ \\
\hline $\begin{array}{l}\text { Manifesto } \\
\text { IFLA/UNESCO } \\
\text { pela biblioteca } \\
\text { multicultural }\end{array}$ & 2008 & Orientação/Diretriz & $\begin{array}{l}\text { Conclamar a comunidade internacional a } \\
\text { reconhecer e apoiar serviços bibliotecário e } \\
\text { de informação em seu papel de promotores e } \\
\text { conservadores da diversidade lingüística e } \\
\text { cultural; conclamar aos responsáveis de } \\
\text { todos os níveis e a comunidade bibliotecária } \\
\text { de todo o mundo a difundir o manifesto e } \\
\text { levar a cabo os princípios e ações que } \\
\text { expressa; complementar o Manifesto } \\
\text { IFLA/UNESCO sobre a Biblioteca pública, } \\
\text { Manifesto IFLA/UNESCO da biblioteca } \\
\text { escolar e o Manifesto sobre Internet da IFLA. }\end{array}$ \\
\hline
\end{tabular}




\section{* Lei no 4.084/1962 de 30 de Junho de 1962}

Segundo Castro (2000), desde os anos de 1930, ocorreram avanços no reconhecimento da Biblioteconomia como profissão de nível superior. No entanto, os bibliotecários viveram o dilema de não terem uma lei que regulamentasse a profissão, até 1962. Castro (2000, p. 152) diz que: "Até 1959, o único reconhecimento legal da profissão do bibliotecário tinha sido feito pelo DASP [Departamento Administrativo do Serviço Público], que a classifica como carreira de nível superior e de natureza técnica e científica.".

A Lei no 4.084/1962 de 30 de junho de 1962 dispõe sobre a profissão de bibliotecário e regula seu exercício (ver Anexo A). Esta Lei foi regulamentada pelo Decreto no 56.725 de 16 de agosto de 1965 (ver Anexo A). Considerando que a lei que regulamenta a profissão é um documento norteador para a formação por, necessariamente, descrever o profissional, bem como suas competências, procuramos em tal "representação" entender "quem é o bibliotecário", do ponto de vista de tal lei quando trata "Do Exercício da Profissão de Bibliotecário e das suas Atribuições":

Art. $1^{\circ}$ - A designação profissional de Bibliotecário, a que se refere o quadro das profissões liberais, grupo 19, anexo ao Decreto-Lei no 5.452, de $1^{\circ}$ de maio de 1943 (Consolidação das Leis do Trabalho), é privativa dos Bacharéis em Biblioteconomia, de conformidade com as leis em vigor.

Art. $2^{\circ}$ - O exercício da profissão de Bibliotecário, em qualquer de seus ramos, só será permitido: a) aos Bacharéis em Biblioteconomia, portadores de diplomas expedidos por Escolas de Biblioteconomia de nível superior, oficiais, equiparadas, ou oficialmente reconhecidas; b) aos Bibliotecários portadores de diplomas de instituições estrangeiras que apresentem os seus diplomas revalidados no Brasil, de acordo com a legislação vigente.

Parágrafo único - Não será permitido o exercício da profissão aos diplomados por escolas ou cursos cujos estudos hajam sido feitos através de correspondência, cursos intensivos, cursos de férias, etc.

Art. 3o - Para o provimento e o exercício de cargos técnicos de Bibliotecários, Documentalistas e Técnicos de Documentação na administração pública federal, estadual ou municipal, autárquica, paraestatal, nas empresas de economia mista ou nas concessionárias de serviços públicos é obrigatória a apresentação de diploma de Bacharel em Biblioteconomia, respeitados os direitos dos atuais ocupantes (redação dada pela Lei no 7.504, de 02/07/1986). 
Art. 4 - Os profissionais de que trata o artigo $2^{\circ}$, letras "a" e "b" desta lei, só poderão exercer a profissão após haverem registrado seus títulos ou diplomas na Diretoria de Ensino Superior do Ministério da Educação e Cultura.

Art. 50 - O certificado de registro ou a apresentação do título registrado, será exigido pelas autoridades federais, estaduais ou municipais para assinatura de contratos, termos de posse, inscrição em concursos, pagamentos de licenças ou imposto para exercício da profissão e desempenho de quaisquer funções a esta inerentes.

Art. 6 - São atribuídas aos Bacharéis em Biblioteconomia, a organização, direção e execução dos serviços técnicos de repartições públicas federais, estaduais, municipais e autarquias e empresas particulares concernentes às matérias e atividades seguintes: a) o ensino de Biblioteconomia; b) a fiscalização de estabelecimentos de ensino de Biblioteconomia reconhecidos, equiparados ou em via de equiparação; c) administração e direção de bibliotecas; d) a organização e direção dos serviços de documentação; e) a execução dos serviços de classificação e catalogação de manuscritos e de livros raros e preciosos, de mapotecas, de publicações oficiais e seriadas, de bibliografia e referência.

Art. $7^{0}$ - Os Bacharéis em Biblioteconomia terão preferência, quanto à parte relacionada à sua especialidade nos serviços concernentes a: a) demonstrações práticas e teóricas da técnica biblioteconômica em estabelecimentos federais, estaduais ou municipais; b) padronização dos serviços técnicos de biblioteconomia; c) inspeção, sob o ponto de vista de incentivar e orientar os trabalhos de recenseamento, estatística e cadastro de bibliotecas; d) publicidade sobre material bibliográfico e atividades da biblioteca; e) planejamento de difusão cultural, na parte que se refere a serviços de bibliotecas; f) organização de congressos, seminários, concursos e exposições nacionais ou estrangeiras, relativas a Biblioteconomia e Documentação ou representação oficial dos Conselhos de Biblioteconomia em tais certames.

No sentido de entender "quem é o bibliotecário" descrito nessa lei, portanto, destacamos o artigo $2^{\circ}$ (transcrito acima), pois diz que o bibliotecário é o bacharel em Biblioteconomia e o artigo 6ำ que diz que tais bacharéis organizam, dirigem e executam serviços técnicos concernentes à administração e direção de bibliotecas, organização e direção de serviços de documentação, execução de serviços de classificação e catalogação de "manuscritos, livros raros e preciosos, de mapotecas, de publicações oficiais e seriadas, de bibliografia e referência". Chama, também, a atenção a afirmação de que o bacharel em Biblioteconomia é aquele que efetua "fiscalização de estabelecimentos de ensino de Biblioteconomia reconhecidos, equiparados ou em via de equiparação". Esses artigos, portanto, desenham o 
bibliotecário como um técnico-controlador que presta e dirige serviços especializados de tratamento e organização de documentos.

No entanto, destacamos no artigo $7^{0}$ que o bibliotecário é definido como, "preferencialmente", um planejador de difusão cultural. "Os Bacharéis em Biblioteconomia terão preferência, quanto à parte relacionada à sua especialidade nos serviços concernentes a [...]: e) planejamento de difusão cultural, na parte que se refere a serviços de bibliotecas". Portanto, se entendermos, nesse caso, o bibliotecário posto como difusor cultural, cabe interrogação sobre o "planejamento de difusão cultural", pois essa "parte" não está evidente no texto. Este diz apenas que é a "que se refere a serviços de bibliotecas". O bibliotecário, "preferencialmente", planeja e formata serviços e depois faz a "difusão cultural" e ainda a "difusão" desses serviços? Ora, a "difusão cultural" demanda preparo, formação que não é apenas técnico-especializada, pois requer domínio, imersão do profissional no universo do cultural, compreensão de suas dinâmicas sociais, políticas, ideologias. Além disso, demanda negociações complexas com os públicos, protagonistas do processo cultural. O que difundir? Como? Para que público? Mediar, para além de "difundir" cultura é, também, questão que não pode ser deixada de lado. Ou seja, os processos de apropriação simbólica exigem mediadores aptos e capazes de intermediar situações de conflitos cognitivos e socioculturais nada simples.

Assim, consideramos que a lei avança pouco na compreensão do bibliotecário como um mediador cultural que entendemos ser um ator privilegiado dos processos de apropriação e protagonismo cultural. Antes privilegia aspectos que o definem como um controlador que ordena, organiza e fiscaliza por meio de seus conhecimentos técnico-especializados. Ao reconhecer esse profissional, a lei deixa escapar os vínculos dele com a sociedade, o conhecimento e a cultura.

\section{* Diretrizes curriculares para os cursos de Biblioteconomia}

Antes de nos concentrarmos nas Diretrizes curriculares para os cursos de Biblioteconomia de 2001, é indispensável fazer referência ao currículo mínimo, de 1962 e às novas orientações curriculares, de 1982, que as antecederam.

Souza (2009) afirma que a luta dos bibliotecários por símbolos de status profissional teve sua primeira conquista em 1958, se referindo, claramente, ao reconhecimento legal da profissão do bibliotecário feito pelo DASP. E, em 1962, foi 
fixado o currículo mínimo do curso de Biblioteconomia pelo Conselho Federal de Educação.

Considerando esse currículo mínimo, Souza (2009) diz que, com mudança de alguns nomes de disciplinas, observa-se uma insuficiente e confusa contribuição da escola de Biblioteconomia na formação do bibliotecário para desempenhar funções nas bibliotecas pública e escolar. Souza $(2009$, p. 87) destaca que:

[...] A duração do curso seria de três anos. As matérias, em número de dez, eram constituídas basicamente por aquelas do currículo importado dos Estados Unidos e implantado em 1936 no Curso do Departamento de Cultura da Prefeitura de São Paulo. A elas se acrescentavam algumas outras matérias tidas de conhecimento humanístico ao futuro bibliotecário.

No entanto, o autor enfatiza que era dada mais atenção às matérias de caráter técnico, conferindo, assim, um perfil técnico aos bibliotecários.

Sobre o currículo mínimo de 1962, Castro (2002) observa que: "Tal currículo visava, entre outros objetivos, atender às necessidades do "mercado biblioteconômico ascendente", ao aumento da produção científica brasileira, que requeria organização e controle, e às técnicas biblioteconômicas que eram o canal privilegiado para isso [...]". E, acrescenta: "[...] para não configurar a formação do bibliotecário como exclusivamente técnica, foram incorporadas algumas disciplinas culturais." $O$ autor observa ainda que :

[...] podemos afirmar que o Currículo Mínimo de 1962, apesar de constituir-se em um marco significativo para a Biblioteconomia, bem como fator decisivo para a obtenção do reconhecimento da profissão em nível universitário, não chegou a satisfazer os professores e a classe bibliotecária, uma vez que não correspondia às expectativas dos profissionais e às exigências dos avanços tecnológicos, sociais e educacionais da época. Seu elenco de disciplinas não permitia um entendimento claro, talvez porque sua elaboração não tenha tomado por base os pressupostos essenciais que deveriam ser considerados para apreciação de um Currículo Mínimo.

O currículo mínimo de 1962 compreendia, portanto, as seguintes matérias:

- História do Livro e das Bibliotecas

- História da Literatura

- História da Arte 
- Introdução aos Estudos Históricos e Sociais

- Evolução do Pensamento Filosófico e Científico

- Organização e Administração de Bibliotecas

- Catalogação e Classificação

- Bibliografia e Referência

- Documentação

- Paleografia

No ano de 1982, foi aprovado um novo currículo, implantado em 1984, decorrente das discussões no âmbito da ABEBD. Jussara Santos (1997, p. 5-6) diz que a proposta do currículo mínimo de 1962 não satisfez o meio acadêmico e, portanto, a $A B E B D$, formada por professores dos cursos de Biblioteconomia, em 1982, "[...] conseguiu a publicação da Resolução n. 08/82 do Conselho Federal de Educação que: 'Fixa os Mínimos de Conteúdo e Duração do Curso de Biblioteconomia'." A autora considera que "O novo currículo teve como proposição ser multidisciplinar, preocupar-se com a organização dos documentos e, também, com o tratamento da informação, destacando o usuário dos serviços e unidades de informação como eixo central." Como descreve, esse currículo é organizado na resolução por três matérias principais e suas subdivisões (com disciplinas obrigatórias e/ou eletivas dentro das referidas matérias):

Matérias de Fundamentação Geral

- Comunicação

- Aspectos Sociais, Políticos e Econômicos do Brasil Contemporâneo

- História da Cultura

Matérias Instrumentais

- Lógica

- Língua Portuguesa e Literatura da Língua Portuguesa

- Língua Estrangeira Moderna

- Métodos e Técnicas de Pesquisa 
Matérias de Formação Profissional

- Informação Aplicada à Biblioteconomia

- Produção dos Registros do Conhecimento

- Formação e Desenvolvimento de Coleções

- Controle Bibliográfico dos Registros do Conhecimento

- Disseminação da Informação

- Administração de Bibliotecas

Castro (2002) também elaborou um quadro (ver Anexo G) da evolução curricular na área de Biblioteconomia no Brasil, de 1911 a 1982, no qual podemos observar os percursos do "humanismo" e do "tecnicismo" nos currículos, o peso quantitativo de disciplinas de uma modalidade ou da outra, além da proposta de introdução da categoria do "usuário".

No entanto, como a proposta deste trabalho não é tratar deles, analisar currículos, mas interrogar a formação do bibliotecário como mediador cultural, partindo do pressuposto de que normas, diretrizes e documentos orientadores da formação tratam a mediação cultural de forma insuficiente e confusa, o documento analisado neste tópico são as Diretrizes Curriculares para os Cursos de Biblioteconomia que constam no Parecer CNE/CES n. 492/2001 (ver Anexo C) das Diretrizes Curriculares Nacionais dos cursos de Filosofia, História, Geografia, Serviço Social, Comunicação Social, Ciências Sociais, Letras, Biblioteconomia, Arquivologia e Museologia:

A Comissão constituída pelas Conselheiras Eunice Ribeiro Durham, Vilma de Mendonça Figueiredo e Silke Weber analisou as propostas provindas da SESu referentes aos cursos mencionados e procedeu a algumas alterações com o objetivo de adequá-las ao Parecer 776/97 da Câmara de Educação Superior, respeitando, no entanto, o formato adotado pelas respectivas Comissões de Especialistas que as elaboraram. A Comissão retirou, apenas de cada uma das propostas, o item relativo à duração do curso, considerando o entendimento de que o mesmo não constitui propriamente uma diretriz e será objeto de uma Resolução específica da Câmara de Educação Superior, o que foi objeto do Parecer CNE/CES 583/2001. (BRASIL, 2001a). 
Nas Diretrizes curriculares para os cursos de Biblioteconomia, portanto, estão listadas, no item "Competências e habilidades", gerais e específicas, o que o documento considera as "típicas desse nível de formação":

\section{$\underline{\text { Gerais }}$}

- Gerar produtos a partir dos conhecimentos adquiridos e divulgá-los;

- Formular e executar políticas institucionais;

- Elaborar, coordenar, executar e avaliar planos, programas e projetos;

- Utilizar racionalmente os recursos disponíveis;

- Desenvolver e utilizar novas tecnologias;

- Traduzir as necessidades de indivíduos, grupos e comunidades nas respectivas áreas de atuação;

- Desenvolver atividades profissionais autônomas, de modo a orientar, dirigir, assessorar, prestar consultoria, realizar perícias e emitir laudos técnicos e pareceres;

- Responder a demandas sociais de informação produzidas pelas transformações tecnológicas que caracterizam o mundo contemporâneo.

\section{Específicas}

- Interagir e agregar valor nos processos de geração, transferência e uso da informação, em todo e qualquer ambiente;

- Criticar, investigar, propor, planejar, executar e avaliar recursos e produtos de informação;

- Trabalhar com fontes de informação de qualquer natureza;

- Processar a informação registrada em diferentes tipos de suporte, mediante a aplicação de conhecimentos teóricos e práticos de coleta, processamento, armazenamento e difusão da informação;

- Realizar pesquisas relativas a produtos, processamento, transferência e uso da informação. 
Nesse documento, destacamos o que é assinalado como competência geral do bibliotecário - atuar na tradução das necessidades de indivíduos, grupos e comunidades à medida que elabora, coordena, executa e avalia planos, programas e projetos, pois, como vimos na pesquisa bibliografia, o mediador cultural executa a negociação cultural, elaborando ferramentas e ambientes de relações, interações e trocas, o que subentende conhecimento e atuação tradutora a serem construídos com o público interessado e envolvido na mediação. Assim, entendemos que, nesse ponto, o documento converge para a visão do bibliotecário como mediador cultural.

Além disso, destacamos a competência específica de: "Interagir e agregar valor nos processos de geração, transferência e uso da informação, em todo e qualquer ambiente". Inferimos que, nesse sentido, também se trata do papel do mediador cultural.

No entanto, o entendimento de como o texto reconhece o mediador cultural fica confuso quando encontramos a utilização da problemática expressão "transferência da informação", que remete à mera passagem ou transmissão de saberes e produtos culturais acabados, prontos para consumo. Portanto, essa noção está contrária à ideia de mediação cultural discutida na pesquisa bibliográfica que coloca o mediador cultural como negociador de sentidos e fins culturais, tendo em vista uma apropriação da informação e da cultura (PERROTTI; PIERUCCINI, 2014; DUFRÊNE; GELLEREAU, 2004b).

No decorrer deste capítulo, na análise das apresentações dos cursos de mediação cultural veremos que essas "Competências e habilidades", gerais e específicas, das diretrizes do MEC coadunam-se com competências descritas em propostas de formação de mediadores culturais (no Brasil e na França), embora no texto das diretrizes não esteja clara, mas insuficiente e confusa, a visão do bibliotecário como mediador cultural.

\section{* Manifesto da IFLA/Unesco sobre bibliotecas públicas}

O Manifesto da IFLA/Unesco sobre bibliotecas públicas (ver Anexo D) foi preparado sob os auspícios da Secção de bibliotecas públicas da IFLA e aprovado pelo Intergovernmental Council for the General Information Programme (PGI) da Unesco, em novembro de 1994. Essa publicação é uma versão de um cartaz e de um folheto publicados pela Unesco, em 1949, intitulado "Biblioteca pública - uma 
força viva da educação popular", ambos foram produzidos para servir de instrumental na promoção dos serviços da biblioteca pública (UNESCO, 1995).

Em 1972, como contribuição ao "Ano Internacional do Livro", a Unesco solicitou à IFLA que revisasse o manifesto para que ele pudesse refletir mudanças ocorridas no papel das bibliotecas públicas, oferecendo um conceito mais amplo das finalidades e objetivos, por entender que as bibliotecas já não se limitavam a apoiar a educação, mas tinham o dever de promover informação e cultura. Entretanto, em 1992, 20 anos depois, a IFLA propôs a revisão da publicação de 1972, o que resultou no Manifesto da IFLA/Unesco sobre bibliotecas públicas de 1994 (UNESCO, 1995).

Consideramos que o Manifesto da IFLA/Unesco sobre bibliotecas públicas (IFLA/UNESCO, 1994) de 1994 é um documento orientador, caracterizando-se como diretriz para o saber, o fazer e a formação do bibliotecário. Esse documento preconiza que as missões-chave da biblioteca pública estão relacionadas com a informação, a alfabetização, a educação e a cultura, que, segundo o documento, são as seguintes:

1. Criar e fortalecer os hábitos de leitura nas crianças, desde a primeira infância;

2. Apoiar a educação individual e a autoformação, assim como a educação formal a todos os níveis;

3. Assegurar a cada pessoa os meios para evoluir de forma criativa;

4. Estimular a imaginação e criatividade das crianças e dos jovens;

5. Promover o conhecimento sobre a herança cultural, o apreço pelas artes e pelas realizações e inovações científicas;

6. Possibilitar o acesso a todas as formas de expressão cultural das artes do espetáculo;

7. Fomentar o diálogo intercultural e a diversidade cultural;

8. Apoiar a tradição oral;

9. Assegurar o acesso dos cidadãos a todos os tipos de informação da comunidade local;

10. Proporcionar serviços de informação adequados às empresas locais, associações e grupos de interesse; 
11. Facilitar o desenvolvimento da capacidade de utilizar a informação e a informática;

12. Apoiar, participar e, se necessário, criar programas e atividades de alfabetização para os diferentes grupos etários.

Evidentemente, há missões-chave, definidas no documento, que estão direcionadas à necessidade de autonomia e de apropriação cultural do público, como as de criar e fortalecer "hábitos" de leitura, apoiar a educação holística do indivíduo e a evolução criativa de cada pessoa, assim como a de estimular a imaginação e a criatividade. Além disso, há missões-chave direcionadas à interculturalidade e outras de apoio à tradição oral e ao acesso a todos os tipos de informação da comunidade local.

O cumprimento dessas "missões" que destacamos, evidentemente, requer atuação profissional e qualificada que compreenda e interfira nos processos de apropriação cultural e da educação holística citada, bem como nas condições de acesso à informação para a referida comunidade local, além de, também, contemplar as questões em torno da interculturalidade. O cumprimento dessas missões requer a atuação do mediador cultural bibliotecário. Nesse manifesto, o profissional bibliotecário é descrito no item "Funcionamento e Gestão":

- Deve ser formulada uma política clara, definindo objetivos, prioridades e serviços, relacionados com as necessidades da comunidade local. A biblioteca pública deve ser eficazmente organizada e devem ser mantidos padrões profissionais de funcionamento.

- Deve ser assegurada a cooperação com parceiros relevantes, por exemplo, grupos de utilizadores e outros profissionais a nível local, regional, nacional e internacional.

- Os serviços têm de ser fisicamente acessíveis a todos os membros da comunidade. Isso supõe a existência de edifícios bem situados, boas condições para a leitura e o estudo, assim como o acesso à tecnologia adequada e aos horários convenientes para os utilizadores. Tal implica igualmente serviços destinados àqueles a quem é impossível frequentar a biblioteca. 
- Os serviços da biblioteca devem ser adaptados às diferentes necessidades das comunidades das zonas urbanas e rurais.

- O bibliotecário é um intermediário ativo entre os utilizadores e os recursos disponíveis. A formação profissional contínua do bibliotecário é indispensável para assegurar serviços adequados.

- Têm de ser levados a cabo programas de formação de potenciais utilizadores de forma a fazê-los beneficiar de todos os recursos.

O documento registra, portanto, que "O bibliotecário é um intermediário ativo entre os usuários e os recursos disponíveis". Sendo assim, inferimos que se trata de um mediador cultural, de acordo com os estudos de Davallon (2007). Para que esse mediador esteja em condições de mediar, a IFLA/Unesco (1994) entende que "A formação profissional contínua do bibliotecário é indispensável para assegurar serviços adequados".

De fato, a formação continuada de qualquer profissional é imprescindível, mas destacamos esse trecho do manifesto no sentido de verificar a descrição do bibliotecário como mediador cultural e indagar sobre a sua formação como tal: ao considerar o bibliotecário um intermediário ativo, o documento o reconhece como um mediador cultural que não atua de forma neutra? Ao considerar a formação continuada no mesmo item, admite que competências para tal intermediação deve ser adquirida em formação continuada? E quando acrescenta que tal formação seja no sentido de assegurar serviços adequados, entende que a mediação e a formação do mediador tem por finalidade a "oferta de serviços"?

Se há o entendimento de que o bibliotecário é por essência um mediador cultural, indagamos se a formação, não só continuada, mas a própria graduação, por exemplo, não deveriam estar direcionada às competências de um mediador? Do mesmo modo, indagamos se há um equívoco em traduzir a mediação como estratégias de formatação de "serviços". É por essas questões que reiteramos a necessidade de definirmos mediação e mediador cultural para, inclusive, identificarmos o profissional bibliotecário entendido como tal. 


\section{* Manifesto IFLA/Unesco da biblioteca escolar}

O Manifesto da biblioteca escolar (ver Anexo E) foi desenvolvido pela IFLA, por meio de sua Seção de Bibliotecas Escolares, e pela International Association of School Librarianship (IASL), sendo posteriormente aprovado pela Unesco. O documento foi preparado em 1998 e publicado em 1999. Foi escrito para que seus princípios sejam aplicados em planejamento, desenvolvimento e serviços da biblioteca escolar, bem como para servir de guia para a sua avaliação (IFLA/UNESCO, 1999). No item “A Missão da Biblioteca Escolar”, temos:

A biblioteca escolar promove serviços de apoio à aprendizagem e livros aos membros da comunidade escolar, oferecendo-lhes a possibilidade de se tornarem pensadores críticos e efetivos usuários da informação, em todos os formatos e meios. As bibliotecas escolares ligam-se às mais extensas redes de bibliotecas e de informação, em observância aos princípios do Manifesto UNESCO para Biblioteca Pública.

O quadro de pessoal da biblioteca constitui-se em suporte ao uso de livros e outras fontes de informação, desde obras de ficção até outros tipos de documentos, tanto impressos como eletrônicos, destinados à consulta presencial ou remota. Este acervo se complementa e se enriquece com manuais, obras didáticas e metodológicas.

Está comprovado que bibliotecários e professores, ao trabalharem em conjunto, influenciam o desempenho dos estudantes para o alcance de maior nível de literacia na leitura e escrita, aprendizagem, resolução de problemas, uso da informação e das tecnologias de comunicação e informação.

Os serviços das bibliotecas escolares devem ser oferecidos igualmente a todos os membros da comunidade escolar, a despeito de idade, raça, sexo, religião, nacionalidade, língua e status profissional e social. Serviços e materiais específicos devem ser disponibilizados a pessoas não aptas ao uso dos materiais comuns da biblioteca.

O acesso às coleções e aos serviços deve orientar-se nos preceitos da Declaração Universal de Direitos e Liberdade do Homem, das Nações Unidas, e não deve estar sujeito a qualquer forma de censura ideológica, política, religiosa, ou a pressões comerciais. (IFLA/UNESCO, 1999).

Destacamos, nesse item, as afirmações de que o quadro de pessoal da biblioteca e, portanto, o bibliotecário constituem "suporte" ao uso de livros e outras fontes de informação, consultados presencial ou remotamente, como também um "apoio" no desempenho da aprendizagem de estudantes. Essas afirmações nos 
fazem inferir que se está descrevendo um bibliotecário difusor, um "educador", que dá acesso às coleções e a oferta de serviços que, consequentemente, farão o estudante alcançar um mais alto nível de aprendizagem e de resolução de problemas. Nesse ponto, não se trata, pois, de um "mediador", mas de um "difusor" cultural. Ainda enfatizando a função de difundir, "dar acesso" e "oferecer serviços", o documento também nos dá a visão de um difusor cultural, no elenco dos "objetivos" da biblioteca escolar, listados abaixo:

- Apoiar e intensificar a consecução dos objetivos educacionais definidos na missão e no currículo da escola;

- Desenvolver e manter nas crianças o hábito e o prazer da leitura e da aprendizagem, bem como o uso dos recursos da biblioteca ao longo da vida;

- Oferecer oportunidades de vivências destinadas à produção e ao uso da informação voltada ao conhecimento, à compreensão, à imaginação e ao entretenimento;

- Apoiar todos os estudantes na aprendizagem e na prática de habilidades para avaliar e usar a informação, em suas variadas formas, suportes ou meios, incluindo a sensibilidade para utilizar adequadamente as formas de comunicação com a comunidade onde estão inseridos;

- Prover acesso em nível local, regional, nacional e global aos recursos existentes e às oportunidades que expõem os aprendizes a diversas ideias, experiências e opiniões;

- Organizar atividades que incentivem a tomada de consciência cultural e social, bem como de sensibilidade;

- Trabalhar em conjunto com estudantes, professores, administradores e pais, para o alcance final da missão e dos objetivos da escola;

- Proclamar o conceito de que a liberdade intelectual e o acesso à informação são pontos fundamentais à formação de cidadania responsável e ao exercício da democracia;

- Promover leitura, recursos e serviços da biblioteca escolar junto à comunidade escolar e ao seu derredor.

Além desses objetivos, também consta que: 
À biblioteca escolar cumpre exercer todas essas funções, por meio de políticas e serviços; seleção e aquisição de recursos; provimento do acesso físico e intelectual a fontes adequadas de informação; fornecimento de instalações voltadas à instrução; contratação de pessoal treinado.

Selecionamos nos objetivos elencados acima os que nos pareceu requerem a atuação de um mediador cultural, porém, de uma atuação no sentido de "oferecer", "apoiar" e "prover". Vejamos:

- Oferecer oportunidades de vivências destinadas à produção e ao uso da informação voltada ao conhecimento, à compreensão, à imaginação e ao entretenimento;

- Apoiar todos os estudantes na aprendizagem e na prática de habilidades para avaliar e usar a informação, em suas variadas formas, suportes ou meios, incluindo a sensibilidade para utilizar adequadamente as formas de comunicação com a comunidade onde estão inseridos;

- Prover acesso em nível local, regional, nacional e global aos recursos existentes e às oportunidades que expõem os aprendizes a diversas ideias, experiências e opiniões.

No item Pessoal, do Manifesto da biblioteca escolar, temos que "o bibliotecário escolar é o membro profissionalmente qualificado" para atuar na biblioteca:

O bibliotecário escolar é o membro profissionalmente qualificado, responsável pelo planejamento e gestão da biblioteca escolar. Deve ser apoiado tanto quanto possível por equipe adequada, trabalha em conjunto com todos os membros da comunidade escolar e deve estar em sintonia com bibliotecas públicas e outros.

O papel do bibliotecário escolar varia de acordo com orçamentos, currículos e metodologias de ensino das escolas, dentro do quadro legal e financeiro do país. Em contextos específicos, há áreas gerais de conhecimento que são vitais se os bibliotecários escolares assumirem o desenvolvimento e a operacionalização de serviços efetivos: gestão da biblioteca, dos recursos, da informação e ensino. 
Em vista do crescimento dos ambientes de rede, os bibliotecários escolares devem tornar-se competentes no planejamento e na instrução das diferentes habilidades para o manuseio de novas ferramentas de informação, tanto a professores como a estudantes. Portanto, devem obter contínuo treinamento e desenvolvimento profissional. (IFLA/UNESCO, 1999).

Sendo assim, conforme o Manifesto, espera-se que o bibliotecário, "profissional qualificado" para planejar e gerenciar a biblioteca escolar, tenha competência para oferecer as condições e o ambiente de produção de informação e de conhecimento. O manifesto refere-se também ao desenvolvimento da sensibilidade, da comunicação, das ideias, de experiências, de opiniões, de consciência cultural e social, da liberdade intelectual, da cidadania e da democracia. Entendemos que tudo isso desenha o bibliotecário como mediador cultural, se considerarmos a discussão desenvolvida no quadro teórico de referência deste trabalho. Todavia, aparece de forma confusa, até retórica, e sob o risco da simplificação, uma vez que as colocações são intenções gerais, próprias dos manifestos.

\section{* Manifesto IFLA/Unesco pela biblioteca multicultural}

O Manifesto IFLA/Unesco pela biblioteca multicultural (ver Anexo F) foi aprovado pelo Comitê executivo da IFLA, em agosto de 2006 e em abril de 2008, pelo Conselho Intergovernamental do Programa de Informação para Todos (IFAP) da Unesco. Esse Manifesto complementa os da IFLA/Unesco sobre a biblioteca pública e sobre a biblioteca escolar, convocando a comunidade internacional a reconhecer e apoiar os serviços bibliotecários e profissionais de informação que, segundo o manifesto, "desempenham o papel de promotores e conservadores da diversidade linguística e cultural".

Esse documento solicita aos responsáveis de todos os níveis e à comunidade bibliotecária de todo o mundo que difundam o Manifesto e levem a cabo os princípios e ações expressas nele (IFLA/UNESCO, 2009). Portanto, dá a entender que deve ser visto como documento orientador para a atuação de bibliotecas e, por conseguinte, para formação e atuação de bibliotecários. 
De acordo com o Manifesto IFLA/Unesco pela biblioteca multicultural de 2008, ao "trabalharem" a diversidade cultural, todos os tipos de bibliotecas funcionam como centros de aprendizagem, de cultura e de informação:

[...] todos los tipos de bibliotecas deben reflejar, apoyar y promover la diversidad cultural y lingüística en los ámbitos locales, nacionales e internacionales, y de esta manera trabajar por el diálogo intercultural y una ciudadanía activa.

Las bibliotecas, al servir a intereses y comunidades diversas, funcionan como centros de aprendizaje, culturales y de información. Al tratar la diversidad cultural y lingüística, los servicios bibliotecarios se rigen por su compromiso con los principios de las libertades fundamentales y la igualdad en el acceso a la información y al conocimiento para todos, en el respeto de la identidad y los valores culturales. [...]

Los servicios bibliotecarios y de información en un contexto de diversidad cultural y lingüística incluyen tanto la oferta de servicios a todo tipo de usuarios de la biblioteca como la oferta de servicios bibliotecarios dirigidos especialmente a grupos culturales y lingüísticos tradicionalmente más desatendidos. Se debería prestar especial atención a grupos que a menudo sufren marginación en las sociedades con diversidad cultural: minorías, refugiados y solicitantes de asilo, personas con permisos de residencia temporales, trabajadores inmigrantes y comunidades indígenas.(IFLA/UNESCO, 2009).

Por esse Manifesto, é esperado do profissional bibliotecário atuação em bibliotecas "multiculturais". O Manifesto evidencia a necessidade de que a biblioteca inclua programas de apoio ao diálogo intercultural, à inclusão dos grupos que sofrem marginalização. No entanto, ao explicar que a diversidade e a multiculturalidade se referem à coexistência e à interação "harmônica" de culturas diferentes, o documento nos faz indagar sobre a compreensão do que seja o bibliotecário mediador cultural. Esse entendimento de que há ou haverá uma coexistência harmônica entre culturas e que é nesse contexto que irá atuar o mediador cultural leva-nos a compreendê-lo como "pacificador cultural", definição que não cabe na perspectiva da apropriação cultural que reivindica, antes, o papel de "negociador cultural". Nesse sentindo, o manifesto desconsidera o ambiente de conflito e negociação inevitável, constante e irrevogável das relações que se dão em ambiente intercultural, conforme Canclini (2009), Corona e Pérez Daniel (2009), Oliveira (2014) e Perrotti e Pieruccini (2014). 
Quanto à descrição do pessoal da biblioteca e, portanto, do bibliotecário, o Manifesto o define como intermediário ativo, um mediador cultural, entre os usuários e recursos informacionais. Assim, temos no item "Personal":

El personal de la biblioteca es el intermediario activo entre usuarios y recursos. Se le debe ofertar educación profesional y formación continua centrada en los servicios a comunidades multiculturales, la comunicación y la sensibilidad intercultural, la antidiscriminación, las culturas y las lenguas.

El personal de una biblioteca multicultural debería reflejar las características lingüísticas y culturales de la comunidad para garantizar la conciencia cultural, reflejar la comunidad a la que la biblioteca presta servicio y promover la comunicación.

O bibliotecário está sendo preparado e, portanto, legitimado para atuar como um mediador cultural para o diálogo intercultural, como postulam a IFLA e a Unesco? E se não está sendo preparado, como concretizar as orientações dos manifestos?

Os discursos sobre saberes e fazeres da profissão são parte vital da elaboração de propostas de formação. Chartier e Hebrard (1995), na obra Discurso sobre a leitura, explicam que, no caso francês, no período pós-guerra, a já instalada corporação profissional de bibliotecários que havia se sobreposto aos professores primários e aos eruditos conservadores nas bibliotecas públicas, se depara com a demanda de integração da documentação e os suportes materiais que, até então conseguiam rejeitar, como a imprensa e a fotografia. O temor era de uma "polivalência desclassificadora". Segundo os autores:

[...] a cultura de referência elaborada por todos os funcionários de biblioteca durante sua formação e as práticas profissionais que o bibliotecário ajustou pouco a pouco à demanda social na sua biblioteca são conhecimentos fortes, reguladores da ação comum e que constituem o alvo impiedoso no qual se confortam as novas proposições [...] a crescente heterogeneidade das práticas profissionais e a diversidade das concepções conflitantes de leitura caminham lado a lado (CHARTIER; HEBRARD, 1995).

A questão da polivalência permanece, na contemporaneidade, e seus efeitos podem ser verificados nas dificuldades que a formação enfrenta na elaboração de suas propostas e, também, como razão da insistente crise de identidade do bibliotecário, pelo menos no Brasil. De fato, práticas profissionais tão diversificadas, que vão desde a organização e representação da informação e dos documentos até 
o trabalho de disseminação, assistência e "educação" do público, podem aumentar as incertezas da formação. Todavia, só mudar currículos, nomes de disciplinas e carga horária tem se mostrado pouco eficaz para resolver dilemas históricos da profissão, ao mesmo tempo em que ter garantido por lei a exclusividade profissional para o exercício de tantas tarefas, também não responde a demandas sociais e definições identitárias.

A afirmação dos autores de que a heterogeneidade de práticas coexistia com também diferentes concepções de leitura que eram conflitantes, especialmente em meio a "crise da leitura pública" na França do pós-guerra, nos suscita uma indagação: as prescrições para a formação dos profissionais bibliotecários, na contemporaneidade, bem como sua crise de identidade, no Brasil, têm relações com a concepção da mediação cultural implícitas nas formações?

Ressaltamos, há uma busca de identidade ou um novo paradigma que não comporta pensar a formação do bibliotecário para um resultado de adição de técnicas ou de simples melhoria dos serviços de interface entre acervo e público. $A$ Associação Brasileira de Educação em Ciência da Informação (ABECIN) que trabalha, dentre outras coisas, no sentido de auxiliar na atualização das propostas pedagógicas adotadas nos vários cursos de Biblioteconomia do país, realizou uma oficina de trabalho, aliada ao Fórum Nacional de Pró-Reitores de Graduação das Universidades Brasileiras, que resultou no documento intitulado "Projeto pedagógico e avaliação da graduação: referências para a renovação e ressignificação do ensino em Biblioteconomia/Ciência da Informação.".

Nesse documento, a ABECIN enfatiza que o Projeto pedagógico pode ser um "instrumento clarificador da ação educativa". Entendemos, portanto, que se está falando de um instrumento clarificador da formação em Biblioteconomia que se tem desenvolvido nas Instituições de Ensino Superior (IES) brasileiras.

Pensar o projeto pedagógico de uma instituição e/ou de um curso, é pensar a construção de sua identidade [...] O projeto pedagógico não se reduz à dimensão pedagógica da instituição/curso, muito menos ao conjunto de projetos e planos isolados de cada professor. Vai mais além: explicita os fundamentos teórico-metodológicos, os objetivos, o tipo de organização e as formas de implementação e avaliação da instituição/curso. Em síntese, é um instrumento clarificador da ação educativa da instituição/curso, em sua totalidade. (ASSOCIAÇÃO BRASILEIRA DE EDUCCAÇÃO EM CIÊNCIA DA INFORMAÇÃO, 2001, p. 11-12). 
Mas é do documento gerado na Oficina Regional de Trabalho Norte/Nordeste, de 2002, reunindo docentes de todo o país, para discutir as questões afetas ao ensino da área, que destacamos trecho alinhado com a nossa tese:

Para se discutir o processo formativo na área de Biblioteconomia e Ciência da Informação, bem como os procedimentos para sua avaliação, é necessário, antes de tudo, refletir sobre os conceitos da área e os procedimentos práticos que constituem o fazer profissional da mesma. Por sua vez, a discussão desses elementos implica estabelecer balizadores para determinar sob que referencial se irá trabalhar a concepção de qualidade a ser buscada no interior do processo formativo. (ASSOCIAÇÃO BRASILEIRA DE EDUCAÇÃO EM CIÊNCIA DA INFORMAÇÃO, 2002, p. 9).

Queremos contribuir para o aprofundamento do debate sobre conceitos que estão implicados na representação e na responsabilidade social do profissional bibliotecário na atualidade e, por conseguinte, na sua formação. Tendo em vista que, segundo Laura Russo (1968), a Biblioteconomia brasileira já se encontrava em crise - gerada, entre outras razões, pelo ensino caracteristicamente técnico e o quase inexistente reconhecimento social do bibliotecário - desde a instalação dos primeiros cursos no país, somos levados a entender porque assim permanece, na atualidade, e quais os caminhos para a sua superação.

Castro (2000, p. 199), citado antes, desenvolveu pesquisa com o objetivo principal de compreender os discursos em torno do ensino de Biblioteconomia no Brasil nos anos 50 e 60. Explica-nos que "os discursos em torno de currículo e dos saberes nele incorporados que contemplam as vertentes humanistas e técnicas constituem-se no foco central da literatura contida na imprensa periódica analisada neste estudo". Inclusive, segundo o autor, o foco da literatura também era o "modelo ideal" de formação.

Nesse ponto, cabe questionar se é procedente oferecer, ou apontar, um "modelo ideal" de formação para o bibliotecário. Mais profícuo seria, talvez, que bibliotecários e formadores se debruçassem sobre as razões e desdobramentos da "crise", definissem sua "existência" e formação, compreendendo, construindo e reconstruindo a identidade profissional e sua função ou responsabilidade social. $O$ entendimento das relações entre mediação e apropriação cultural poderia abrir caminhos para discernirmos o desenvolvimento e a formação do bibliotecário, para alcançarmos também seu reconhecimento social. 
O bibliotecário visto como mediador cultural foi procurado nas "descrições" do profissional contidas em documentos orientadores e normativos para a sua formação, considerando o papel norteador que esses documentos desempenham na elaboração e no desenvolvimento das formações de bibliotecários. Constatamos dificuldades na compreensão do lugar da mediação cultural na formação. Em geral, prevalece a compreensão de bibliotecário como disseminador e difusor cultural, quando não a de pacificador, opção que elimina o "conflito" - categoria própria às dinâmicas culturais -, a ser considerado nas mediações culturais, em especial, em um mundo globalizado, em que diferentes culturas se amontoam, se complementam, se enriquecem, mas também se chocam e se disputam.

O mediador atua em quadros vivos e dinâmicos, sujeitos a movimentos que requerem saberes e fazeres especiais e inventivos, próprios, das mediações culturais. Viabilizar diálogos culturais na diferença é um problema especial a ser enfrentado por bibliotecários e demais "profissionais da informação" de nossa época.

\subsection{Propostas de formação em mediação cultural, na França e no Brasil}

Visando o alcance dos objetivos desta tese, selecionamos propostas que "revelam" entendimentos do mediador cultural, suas competências e atuação. O Quadro 2 apresenta os cursos selecionados, sua categoria e o país onde é realizado.

Quadro 2: Propostas de cursos em mediação cultural

\begin{tabular}{|l|c|c|}
\hline \multicolumn{1}{|c|}{ Curso } & \multicolumn{1}{|c|}{$\begin{array}{c}\text { Categoria } \\
\text { País }\end{array}$} \\
\hline $\begin{array}{l}\text { Mestrado em Mediação cultural, patrimônio e digital - Universidade de } \\
\text { Paris, Ouest Nanterre La Défense e Universidade de Paris } 8 \\
\text { Vincennes Saint-Denis / França }\end{array}$ & $\begin{array}{c}\text { Pós-graduação } \\
\text { França }\end{array}$ & França \\
\hline $\begin{array}{l}\text { Mestrado em mediações da cultura e dos patrimônios - Université de } \\
\text { Avignon / França }\end{array}$ & Pós-graduação & França \\
\hline $\begin{array}{l}\text { Licenciatura de mediação cultural: Concepção e implementação de } \\
\text { projetos culturais - Université Sourbonne Nouvelle - Paris 3 / França }\end{array}$ & Graduação & Brasil \\
\hline $\begin{array}{l}\text { Especialização em Mediação em Arte Cultura e Educação - Escola } \\
\text { Guignard-UEMG / Brasil }\end{array}$ & Pós-graduação & \\
\hline $\begin{array}{l}\text { Especialização em Mediação cultural - UFPE / Brasil } \\
\text { Bacharelado em Letras - Artes e Mediação Cultural - UNILA / Brasil }\end{array}$ & Graduação & Brasil \\
\hline
\end{tabular}




\section{* Mestrado em Mediação cultural, patrimônio e digital - Universidade de Paris Ouest Nanterre La Défense e Universidade de Paris 8 Vincennes Saint- Denis $^{5}$}

Apresentação

Os estudantes devem trabalhar no encontro do patrimônio com o digital, familiarizando-se com a diversidade dos métodos, das práticas e dos objetos de estudos que não param de surgir e de se reconfigurar nesta paisagem em constante mudança técnica, estratégica e conceitual. Os estudantes são sistematicamente encorajado(a)s a imaginar e desenvolver novas abordagens profissionais nestas áreas. Eles são convidados a aprofundar as questões relacionadas com:

- a pesquisa, a coleta, a análise, a gestão e a disseminação de informações: a partir de fontes multimídias; de documentos de arquivos de todo tipo;

- a análise e a implementação social de imagens e estruturas visuais de todo tipo, principalmente no campo da criação artística: processo de produção artística; obras em sua materialidade (incluindo aquelas resultantes de novas tecnologias, para época contemporânea); teorias da arte e os fenômenos de representação (incluindo, por esse último, as contribuições da história das mentalidades);

- a diversidade de usos do digital para a mediação cultural, da documentação do patrimônio aos diferentes modos de valorização.

Competências

As instituições patrimoniais (museus, bibliotecas, arquivos, monumentos históricos e grandes sítios patrimoniais), bem como as agências de serviços no campo da cultura e do patrimônio precisam de mediador/mediadora cultural tendo uma dupla competência: conhecimentos fundamentais em ciências humanas e sociais; uma sólida formação teórica e aplicada às tecnologias digitais da documentação, do arquivamento, da infografia e a todos os tipos de escrituras digitais.

Atuação

Criador de programas de mediação. Gerente de projeto digital. Mediador digital. Diretor de comunicação. Diretor dos públicos.

\footnotetext{
${ }^{5}$ Disponível em: http://www.univ-paris8.fr/Master-Mediation-culturelle. Acesso em: jun. 2015.
} 
Responsável pelos estudos documentais. Assistente qualificado de conservação. Responsável pela conservação.

A proposta do Mestrado em Mediação cultural, patrimônio e digital preconiza que o mediador cultural é aquele que possui conhecimentos fundamentais em Ciências Humanas e Sociais, bem como solidez teórica de conhecimentos das tecnologias digitais da documentação, do arquivamento e dos registros digitais.

Nessa proposta, entende-se que o mediador cultural é capaz de realizar o encontro do patrimônio com o digital, necessário nas instituições patrimoniais, de forma inventiva e inovadora, já que atua no contexto das constantes mudanças que configuram a contemporaneidade. Faz parte desse trabalho o desenvolvimento de aportes e instrumentos para visualização e disseminação da informação artística, por meio de uma devida análise dos fenômenos da representação.

Nesse sentido, e tendo em vista a ênfase dada à convergência digital, é entendido que, além de atuar como o criador de programas de mediação ou gerente de projetos digitais, o mediador cultural também pode ser o responsável por estudos ou conservação de documentos. Inferimos, portanto, que nesse caso entende-se o mediador cultural como um curador - especificamente um curador digital.

Mas se o mediador cultural é também aquele que inventa, cria, inova, ele também é produtor no universo da cultura. $\mathrm{E}$ se, como ator, trata a informação ou seus suportes para visualização e disseminação dos conteúdos, ele é um interventor, diferente de um transmissor, e nada tem de coadjuvante no percurso cultural. Ele protagoniza, tal como apontam Perrotti e Pieruccini (2014), junto ao público e a outros criadores, a "narrativa" da negociação de sentidos e valores da vida cultural. 


\section{* Mestrado em Mediações da Cultura e dos Patrimônios - Université de Avignon $^{6}$}

Apresentação

Tem como objetivo a aquisição de conhecimentos sobre as organizações, os campos, as ferramentas, os usuários dos setores da cultura e do patrimônio.

O Mestrado Mediações da Cultura e dos Patrimônios (exposições, culturas digitais, turismos) oferece pontos de referência e ferramentas para compreender a evolução das formas tradicionais como a exposição, a interpretação ou mesmo as formas de desenvolvimento, como as mediações de eventos, digitais, nômades e humanas.

A referência à Estratégia de Desenvolvimento Cultural que rege este mestrado dá guias teóricas e metodológicas, ferramentas e técnicas, permitindo o exercício de uma profissão, uma experiência e uma prática de campo apoiada em um trabalho de reflexão. Ela permite entender as transformações da cultura graças a um laboratório reconhecido internacionalmente.

\section{Competências}

As competências a adquirir nos dois anos do mestrado Mediações da Cultura e dos Patrimônios (exposições, culturas digitais, turismos) são reunidos em quatro grupos:

- Adquirir os fundamentos para a comunicação cultural (Mestrado 1 $1^{\circ}$ semestre).

- Construir um projeto profissional e ferramentas de ações estratégicas (Mestrado 1 - 2o semestre).

- Avaliar, criar um projeto e programar a ação cultural (Mestrado 2 $1^{\circ}$ semestre).

- Realizar uma pesquisa ou ações profissionais (Mestrado 2 - $2^{\circ}$ semestre).

Cada um desses grupos organiza uma transferência de conhecimentos (da cultura e da ação) e uma aquisição de conhecimento (domínio das ferramentas e das técnicas de mediação) nas áreas de exposição, das mídias informatizadas, da museologia e da avaliação.

\footnotetext{
${ }^{6}$ Disponível em: http://www.univ-avignon.fr/fr/formations/choix/fiche/diplome/master-mediations-de-laculture-et-du-patrimoine/presentation.html. Acesso em: jun. 2015.
} 
Atuação

O Mestrado Mediações da cultura e dos Patrimônios (exposições, culturas digitais, turismos) prepara para as funções de: Programação, cenarização, implementação, gestão e avaliação de dispositivos de mediação.

De acordo com a proposta do Mestrado em Mediações da cultura e dos patrimônios, o mestre mediador cultural deve ser conhecedor dos fundamentos da comunicação cultural, capaz de desenvolver ferramentas de ações estratégicas, bem como de criar programas e gerenciar projetos de mediações.

O mediador cultural, nessa perspectiva, é aquele que adquire e aplica o seu conhecimento do público, das organizações e das ferramentas do campo da cultura. Seu trabalho reflexivo e de pesquisa deve incidir sobre a compreensão das dinâmicas na área de exposições, das mídias informatizadas da museologia e da avaliação. O foco dessa proposta é preparar para as funções de programação, cenarização, implementação, gestão e avaliação de dispositivos de mediação.

Portanto, entendemos que nesse caso o mediador cultural é um participante das dinâmicas culturais que reflete seu contexto, como também o avalia para a proposição de ações.

\section{* Licenciatura de Mediação Cultural: concepção e implementação de projetos culturais - Université Sourbonne Nouvelle - Paris $3^{7}$}

Apresentação

O grau destina-se a preparar os estudantes para as carreiras de mediação cultural, principalmente a concepção e a organização de eventos, em festivais, centros culturais, coletividades locais, teatros, museus e todas as estruturas que trabalham no campo da cultura.

Para atender as exigências ao mesmo tempo teóricas, técnicas e profissionais, a licenciatura de Mediação Cultural propõe em primeiro uma consolidação da cultura geral: introdução à sociologia, história cultural, análise de mitos, história da arte, etc. Por outro lado, o estudante adquire habilidades indispensáveis para o exercício das

\footnotetext{
${ }^{7}$ Disponível em: http://www.univ-paris3.fr/medias/fichier/licence-mediationculturelle_1415893284617.pdf. Acesso em: jun. 2015.
} 
profissões de mediação cultural: realização de pesquisa, estatísticas, introdução ao direito, economia aplicada à cultura, etc.

A língua estrangeira ensinada é predominantemente inglês cujo domínio é essencial nos setores da cultura.

O estudante tem também aulas de informática e de construção de um projeto profissional, permitindo-lhe familiarizar-se com a realidade das possíveis profissões no setor da cultura.

\section{Competências}

Os alunos têm aulas teóricas para adquirir uma sólida cultura geral literária, histórica e artística, bem como vastos conhecimentos nas áreas da sociologia da cultura;

A formação proposta está centrada em um forte conhecimento dos domínios artísticos e culturais, bem como na aquisição das ferramentas necessárias para a concepção e implementação de projetos culturais e, em última análise, para as necessárias funções de direção e gestão de instituições ou eventos culturais públicos ou privados.

\section{Atuação}

Setores profissionais e empregos associados a esta licenciatura: as instituições culturais, públicas, privadas e associativas recrutam mediadores culturais, programadores e designers cultural para garantir missões de organização e orientação: as coletividades locais, serviços culturais, museus, teatros e outras cenas, rádio e televisão, marcas, fundações, mediatecas, editoras, galerias de arte, festivais, eventos culturais etc. Atualmente, os alunos saindo da licenciatura encontram empregos como assistentes ou colaboradores de responsáveis pelas decisões na área cultural.

O mediador cultural, de acordo com a proposta da Licenciatura de Mediação Cultural: concepção e implementação de projetos culturais, é um conhecedor dos domínios artísticos e culturais e das ferramentas para concepção e implementação de projetos culturais.

Esse mediador cultural deve estar apto para o desenvolvimento de uma economia da cultura e da pesquisa porque tem uma sólida cultura geral literária, artística e histórica, aliada aos conhecimentos da sociologia da cultura. Por isso, o mediador cultural é o profissional requisitado para organizar e orientar as coletividades locais, serviços culturais, museus, teatros, galerias de arte, festivais, entre outros. 
Dessa forma, entendemos que a proposta coloca o mediador como um consultor que colabora nas decisões da área cultural. Inferimos também que o profissional mediador é colocado na posição de gerente de projetos culturais, mas cujo conhecimento não pode estar restrito às técnicas de gerenciamento, já que os produtos culturais a serem desenhados e entregues são dinâmicos por estarem imbricados no percurso e nos diálogos socioculturais.

\section{* Especialização em Mediação em Arte, Cultura e Educação - Escola Guignard da UEMG ${ }^{8}$}

Apresentação

Capacitar profissionais das mais diferentes áreas, através de uma perspectiva interdisciplinar, para a formulação, planejamento, execução e avaliação de projetos e ações de mediação.

Competências

Formação de profissionais capacitados para atuar na interface entre arte, cultura e educação. À medida que a integração entre esses campos passa a ocupar um lugar central nas práticas de desenvolvimento humano, organizando ações que buscam promover a cidadania, a memória e as transformações sociais, abrem-se novas perspectivas de trabalho e de investigação.

Atuação

Amparadas por uma série de documentos legais e programas oficiais - Plano Nacional de Cultura, Programa Mais Cultura nas Escolas, Parâmetros Curriculares Nacionais em Arte, Plano Nacional de Educação Museau, etc. - as oportunidades de mediação estão em toda parte: escolas, museus, centros culturais, ONGs, Conselhos Municipais de Cultura, entidades e programas ligados à preservação do Patrimônio Histórico e Cultural e à diversidade cultural, etc.

A especialização em Mediação em Arte Cultura e Educação - Escola Guignard-UEMG concebe o mediador cultural como aquele que atua na interface entre arte, cultura e educação, considerando que estes campos integrados ocupam centralidade em práticas que visam o desenvolvimento humano.

\footnotetext{
${ }^{8}$ Disponível em: http://www.uemg.br/pos_unidades.php. Acesso em: jun. 2015.
} 
Tal desenvolvimento requer ações que viabilizem a cidadania, a memória e as transformações sociais. A formulação, o planejamento, a execução e avaliação de projetos e as ações de mediação cultural - em escolas, museus, centros culturais, entidades e programas ligados à preservação do patrimônio histórico e cultural, entre outros - são esperadas do mediador cultural.

O mediador cultural que a proposta apresenta é, portanto, um ator social que elabora conexões necessárias entre elementos da vida social, colaborando para o desenvolvimento humano, pois favorece a comunicabilidade e a negociação de significados, sentidos, saberes e expressões culturais.

\section{* Especialização em Mediação cultural - UFPE ${ }^{9}$}

Apresentação

Formar profissionais para a mediação e conseqüente introdução de usuários de informação e cultura nas diversas linguagens e propostas culturais.

Competências

Profissionais habilitados e que tenham condições de interagir com os diversos públicos, na medida em que esses devem se apropriar dos bens culturais e da informação que gera conhecimentos. A mediação é caracterizada, assim, como um dos fundamentos para a circulação de informação e cultura na sociedade do conhecimento, no sentido de despertar o interesse e tornar viável a interação, a discussão e a crítica cultural.

\section{Atuação}

[Não há menção sobre atuação].

Para o curso de especialização em Mediação cultural da UFPE, o mediador cultural é aquele que torna viável a interação, a discussão e a crítica cultural porque introduz públicos nas linguagens e propostas culturais, como copartícipe do

9 Disponível em: http://www.dci.ufpe.br/index.php?option=com_content\&view=article\&id=303:cursode-especializacao-em-mediacao-cultural-pos-graduacao-lato-sensu\&catid=2\&ltemid=122. Acesso em: jun. 2015. 
processo de apropriação e de protagonismo cultural.

Nessa perspectiva, a mediação e o mediador cultural são imprescindíveis à dinâmica, democratização e apropriação dos saberes, bens e circuitos culturais pelos variados públicos. O mediador cultural é, portanto, um elemento da comunicabilidade dos acervos, tangíveis e intangíveis, das linguagens e expressões culturais e interage com protagonistas culturais em processos de criação de conhecimento e cultura.

\section{* Bacharelado em Letras - Artes e Mediação Cultural da UNILA (Paraná) ${ }^{10}$}

\section{Apresentação}

Formação disciplinar na área de linguística, literatura e tradução no campo das artes visuais e da performance, a fim de propor um novo perfil de egresso que contemple a contemporaneidade dada pelo dinamismo entre diferentes suportes da arte.

Da escritura à oralidade e do drama às culturas digitais, o curso oferece ao bacharel em Letras conhecimentos do campo visual para favorecer, além dos campos de pesquisa em literatura, linguística e tradução, o perfil inédito de um mediador cultural.

Tem o objetivo de promover a reflexão crítica do pensamento latinoamericano sem deixar de lado tanto as genealogias da arte e da literatura, como as políticas linguísticas, a fim de alcançar a inclusão de minorias, considerando as assimetrias impostas.

\section{Competências}

A perspectiva cultural de descolonização da mente propõe outras possíveis racionalidades e tramas sociais da linguagem. $O$ enfoque no presente e nas comarcas culturais, com suas dinâmicas e negociações, visa discutir a heterogeneidade dos saberes. Imagem, corpo, voz e memória incidem no território político-social para traduzir e criar demandas comunitárias.

O egresso deverá ser capaz de incidir sobre tais processos sociais através da gestão (mediação) cultural e/ou através da reflexão e produção acadêmica, com a possibilidade de inserção em diferentes cursos de pós-graduação.

\footnotetext{
${ }^{10}$ Disponível em: https://unila.edu.br/cursos/letras\#descricao-tab. Acesso em: jun. 2015.
} 
Atuação

Em territórios marcados pela assimetria cultural, suas áreas de atuação serão, portanto, a de configurar as políticas culturais e linguísticas públicas (bibliotecas, museus, associações comunitárias, etc) e privadas (ONGs, empresas) que permitam desocultar, ativar e cultivar o saber das línguas e das linguagens na conquista de espaços de convivialidade e humanismo.

O Bacharelado em Letras - Artes e Mediação cultural da UNILA preconiza que o mediador cultural é aquele que se reflete em processos de "descolonização da mente" e, portanto, compreende outras racionalidades e tramas sociais da linguagem. O mediador cultural, nessa proposta, é aquele que "desoculta" e cultiva os saberes da língua e da linguagem numa perspectiva humanística e de convivialidade.

A proposta objetiva o alcance da inclusão de minorias com o aporte da reflexão crítica do pensamento latino-americano e os conhecimentos do campo visual, da literatura, linguística e tradução que o mediador deve colocar em ação. Além disso, expõe seu enfoque na contemporaneidade e comarcas culturais que demandam negociações.

Por isso, compreendemos, o mediador está descrito como um negociador cultural. Inferimos que esse negociador valoriza e viabiliza a dialogia. Sua ação e intervenção - por meio de dispositivos - sobre textos, acervos, e sobre os repertórios humanos e culturais, o caracteriza.

Nessa proposta, chama a atenção a referência à atuação em territórios marcados por "assimetrias culturais", ou seja, compreende-se a mediação - e o mediador - como instância afirmativa, capaz de "ler" os contextos em que se insere e, a partir daí, atuar no sentido de superação de obstáculos à apropriação, bem como aos diálogos culturais. De acordo com as descrições das propostas, reconhece-se, portanto, a importância de estabelecimento de nexos entre métodos e recursos disponibilizados e os contextos e sujeitos que com eles se vincularão.

Procedimentos, técnicas, modos de fazer e instrumentos só ganham valor em relação aos quadros culturais em que se inserem e às perspectivas que representam. Por isso, é preciso que a formação prepare os profissionais para a "leitura cultural" de seus contextos e suas ferramentas profissionais, pois elas não são neutras, são dispositivos e, enquanto tal carregam intenções, direções, modos de perceber, de representar e de atuar no mundo. 
Nesse sentido, os programas de formação, em que pese distinções de várias naturezas, deixam clara a percepção de que a mediação não é apenas uma operação técnico-especializada. Ela é, antes, um ato de interlocução a favor de diálogos culturais, em contextos e situações objetivas que necessitam ser "lidas" adequadamente pelos mediadores. Trata-se, portanto, de ação específica e especializada, envolvendo relações entre sujeitos e culturas, dimensão que implica conhecimentos tanto do primeiro como do segundo termo, além de conhecimentos especializados próprios de seu fazer, envolvendo questões de gestão, implementação e avaliação de projetos culturais. 


\section{FORMAÇÃO DO BIBLIOTECÁRIO COMO MEDIADOR CULTURAL: desafios}

Battles (2003), na obra $A$ conturbada história das bibliotecas, afirma que podemos encontrar retratos do bibliotecário do século XIX na literatura profissional e também na imprensa, como aquele que luta para moldar as preferências do público da biblioteca, dotado dos sentimentos de presunção e piedade por "seus" leitores. No entanto, segundo Battles (2003, p. 125):

[...] os bibliotecários viram-se, de repente, num mundo fraturado, no qual novas forças haviam entrado em ação [...] um dos motes por bibliotecas públicas que varreu a Europa Ocidental e as Américas, no século XIX, dizia "um livro para cada pessoa". Mas a busca por essa história pessoal havia sido um dilema existencial muito antes de se tornar um tema para a Bibliotecologia.

O autor afirma ainda que a expansão da produção em massa de livros, nesse período, fez crescer de forma súbita o volume dos acervos das bibliotecas europeias e americanas e conta o caso da biblioteca do Museu Britânico para ilustrar a "conturbada" coexistência de posturas do bibliotecário em relação à organização e ao público.

Assim, o autor identifica no trabalho de Antonio Panizzi, ex-militante político italiano - a quem, com razão, atribui uma atração por ideologias progressistas, à frente da biblioteca -, uma mostra de como um catálogo pôde passar de um simples inventário a um "instrumento de descoberta": "Sentimo-nos tentado a dizer que sua descoberta de intertextualidade entre livros absolutamente prosaicos prefigura 0 mundo interconectado da era digital. De nosso ponto de vista, o trabalho de Panizzi parece muito um antecessor da Internet." (BATTLES, 2003, p. 134).

As ponderações de Battles sobre Panizzi como alguém com compromisso democrático e que via o catálogo da biblioteca como instrumento de conhecimento e de transformação social dizem respeito às questões levantadas nesta tese. Evidentemente, Panizzi causou descontentamento em muitos cavalheiros, mesmo quando o que pretendia era: "[...] fazer com que a biblioteca ficasse mais transparente para seus leitores, substituindo os mistérios de seu funcionamento por uma sofisticação que contribuiria para a independência do leitor." (BATTLES, 2003, p. 137). 
Porém, como nos explica Battles (2003), não era bem isso que povoava a mente do status quo do final do século XIX, na Inglaterra. Ao verem nas bibliotecas um instrumento de educação das massas, revolucionárias ou não, ao definirem o acesso à informação e, portanto, aos acervos culturais, tal acesso serviria muito mais para "introduzir sensatez" e treinar consumidores do que para emancipar as massas, abrindo-Ihes novas possibilidades de criação de conhecimentos culturais. Para Battles (2003, p. 138), no caso da aprovação da lei de bibliotecas públicas, em 1850, pelo parlamento inglês: "Eles esperavam que as bibliotecas canalizassem as exigências subversivas de uma classe baixa, a quem sempre fora negado o acesso à cultura.".

O legado de Melvil Dewey, segundo Battles, ia em outra direção, distinta de Panizzi:

Para ele [Dewey], interesses locais e necessidades especiais importavam muito menos que a circulação eficiente dos livros pelas mãos dos leitores. Sua confiança inabalável na eficiência repetitiva sem criatividade levou as bibliotecas a fazerem enorme economia, adotando não apenas seu mobiliário e seu método de classificação, como também o recém-criado catálogo de fichas. Mas as reformas foram feitas a expensas da diversidade local, que faz com que valha a pena visitar diferentes bibliotecas independentes e passar horas lendo dentro delas. (BATTLES, 2003, p.145).

Segundo Battles (2003), a inclusão das mulheres na profissão foi apropriada por Dewey, que as admitiu já na primeira turma da Escola de Economia de Bibliotecas que fundou em Colúmbia. Mas, enfatiza o autor, que isso não seja visto como conquista de direitos das mulheres, pois a ideia era de que o profissional ideal presumia características subalternas, devendo estar abaixo de professores e pesquisadores, ainda que houvesse uma outra visão em concorrência que preconizava o bibliotecário como "professor", entendido contudo como controlador do fluxo de livros. As Figuras 5 e 6 são imagens que nos permitem estabelecer ligações com as afirmações de Battles. 
Figura 5: Bibliotecárias do final do século XIX



Minnie Oakley e Florence Baker Hayes, duas bibliotecárias da Wisconsin State Historial Society Librarinas, 1896.

Fonte: Temple, M. 25 Vintage Photos of Librarians Being Awesome ${ }^{11}$.

Figura 6: Humanismo e técnicas para um público

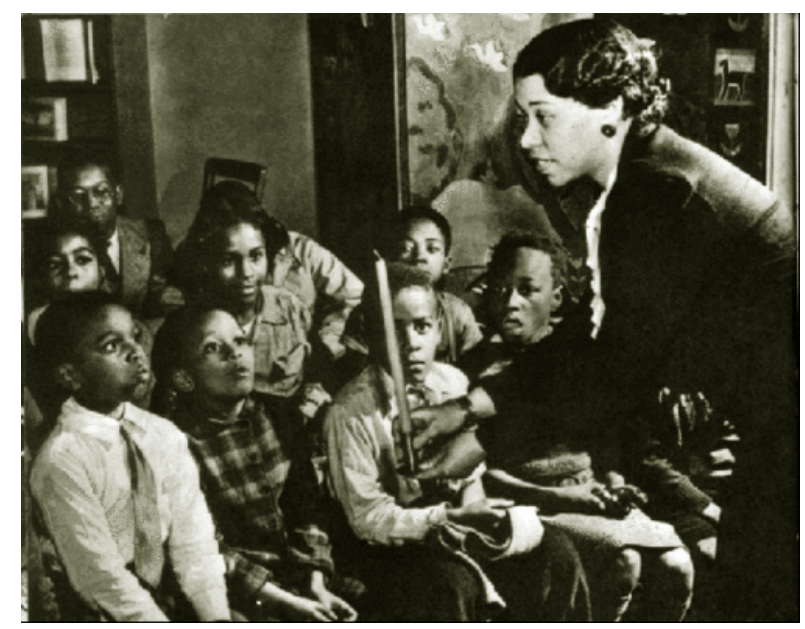

Augusta Baker, que trabalhou em Serviços para Crianças no The New York Public Library 1937-1974.

Fonte: Temple, M. 25 Vintage Photos of Librarians Being Awesome ${ }^{12}$

\footnotetext{
${ }^{11}$ Disponível em: http://flavorwire.com/387224/25-vintage-photos-of-librarians-being-awesome. Acesso em: jun. 2015.

${ }^{12}$ Idem.
} 
A tensão entre técnica e cultura, especialização e erudição, portanto, observada no relato sobre Panizzi e Dewey, é recorrente não só no panorama internacional.

\subsection{Humanismo ou técnica: falso dualismo}

Em seu estudo, Souza (2009) aponta para a formação em Biblioteconomia no Brasil, na década de 1950, indicando um conservadorismo do currículo das escolas que desconsideravam necessidades e características dos públicos, fossem urbanos e rurais. Situação implicada num currículo carente de subsídios para o estudo do público e "sua humanidade" (SOUZA, 2009).

Além disso, Castro (2000) esclarece na sua obra História da Biblioteconomia brasileira que, na formação humanística, de influência francesa, que caracterizou o curso da Biblioteca Nacional, havia a disciplina Bibliografia com o conteúdo técnico de catalogação e classificação, não justificando a "necessidade" de abandono dos aspectos culturais da profissão pelo posterior tecnicismo adotado no Brasil. Ou seja, uma formação humanística não prescinde, obrigatoriamente, das técnicas, tampouco uma formação técnica prescinde de "humanidade".

Sendo assim, e considerando o bibliotecário um mediador cultural, exige-se uma formação humanística porque a mediação cultural é um ato complexo e está implicada em relações e interações socioculturais e de superação de obstáculos à apropriação cultural. Por outro lado, para que atue como mediador cultural é requerido que o bibliotecário conheça e elabore métodos, técnicas e ferramentas nos contextos culturais, e de "diferenças", junto aos sujeitos e públicos que se vinculam, com o subsídio de uma formação técnica.

Almeida Júnior (2002) observa que o campo da Ciência da Informação - em que se situa cientificamente a formação em Biblioteconomia -, caminha em direção à subdivisão, enquanto a conjuntura requer aglutinação. $O$ autor explica que isso ocorre, possivelmente, pela tentativa de "treinamento" do profissional para as momentâneas demandas do mercado. Assim, adverte: "[...] essa necessidade de mercado é momentânea, acarretando, tão logo deixe de existir, a inutilidade dos profissionais preparados apenas para atendê-la." (ALMEIDA JÚNIOR, 2002, p. 136). 
Esse autor observa uma crise de profissões não relacionada ao mercado de trabalho, mas resultado da globalização que imputa a necessidade de um profissional com conhecimentos específicos, mas que extrapole os espaços de atuação convencionados, demonstrando consciência da integralidade e do desenvolvimento humano como fim de toda a ação profissional. E, concordamos com o autor que, no caso dos bibliotecários, há também uma perturbação: "O mercado para o bibliotecário só pode ser ocupado por aqueles que são devidamente qualificados. O problema é que não exige competência, mas diploma." (ALMEIDA JÚNIOR, 2002, p. 134).

Aos falarmos de conhecimentos, competências e diploma exigidos pelo mercado, somos levados a refletir sobre a formação desses profissionais, não apenas problematizando as exigências do mercado, mas atentando para necessidades e expectativas da sociedade. Nesse sentido, Almeida Júnior (2002) alerta que uma mudança de perfil do profissional, por exemplo, não deve estar exclusivamente atrelada à satisfação do mercado, na medida em que os interesses mercadológicos nem sempre são decorrentes de uma necessidade social. Para o autor, "o mercado, dentro dessa perspectiva, se constitui um ponto a ser observado e considerado quando da delimitação do perfil do profissional que embasará toda a estrutura e todo o processo de formação dele." (ALMEIDA JÚNIOR, 2002, p. 136).

Quanto à formação, segundo Almeida Júnior (2002), o espaço de formação universitário irá permitir a confrontação das formas de pensar sobre variados temas, mas, especialmente, os vinculados à formação profissional. No entanto, o autor nos lembra que o "perigo" está nos possíveis conflitos de interesses entre os docentes em relação ao perfil profissional. Consideramos que, certamente, esse cenário tem implicações no currículo, mas concordamos com o autor que, sobretudo, tem implicações no estereótipo do profissional bibliotecário, pois a existência de concepções estereotipadas da área, pelos egressos das universidades, é, também, "culpa" da formação.

No entanto, a reflexão do autor pertinente às questões desta tese diz respeito à sua observação de que o trabalho de mediação da informação tem pouco status entre os profissionais do campo da Ciência da Informação. Embora essa mediação nas unidades de informação ligadas a empresas ou a informações especializadas seja uma prioridade. 
Entendemos que o pouco status do "trabalho de mediação da informação" se deve à falta de entendimento da mediação cultural, e, consequentemente, da mediação da informação, como algo intrínseco à profissão de bibliotecário em qualquer de suas atividades. Por isso, atentamos para a teorização e concepção da mediação da informação e da cultura na formação do bibliotecário.

Nesse sentido, indagamos se o bibliotecário tem assumido uma postura crítica sobre sua formação e atuação. Valentim (2000b, p. 137) diz que para que o profissional possa adotar uma postura crítica de sua atuação deve encontrar respostas sobre quais devem ser suas competências e habilidades nos "projetos pedagógicos de curso de forma clara e objetiva".

Em artigo sobre a formação acadêmica e identidade de bibliotecários no Brasil, Souza (2006) identifica duas expectativas dos indivíduos em relação ao seu ingresso numa universidade. Uma delas é o desenvolvimento de competência para o exercício de uma profissão; a outra é sobre sua competência para a investigação científica. No caso dos bibliotecários, para Souza (2006), a investigação científica não se configura como uma prioridade e há um sentimento de inferioridade no ambiente de exercício profissional, no Brasil.

Souza (2006) argumenta que as interpretações sobre a formação de bibliotecários e cientistas da informação, no contexto brasileiro, dão a entender que o formado em Biblioteconomia atua na execução técnico-gerencial, enquanto o formado em Ciência da Informação atua na realização de pesquisa ou ensino, embora esses profissionais estejam sendo denominados genericamente de "profissionais da informação", o que, segundo ele, não esclarece e até impossibilita a distinção.

A mediação cultural - termo mais amplo que em nosso entendimento engloba a mediação da informação, por ser a informação um objeto cultural - requer do mediador competências e atitudes de um protagonista cultural, para atuar como tal junto a outros protagonistas, com conhecimentos interdisciplinares e consciência de sua função social. Mas, conforme Almeida Júnior (2002, p. 142) pontua, a segmentação das áreas de conhecimento na universidade acaba por alimentar "[...] a ideia de que os estudantes devem apenas se preocupar com a sua formação, como se esta ocorresse tão somente nas carteiras e completamente isolada". E, portanto, "A partir disso, pode-se tentar explicar os motivos que levam os estudantes 
a reivindicarem, com frequência, ênfase na 'prática'. O que significa exatamente essa prática, poucos se atrevem e conseguem explicar." (ALMEIDA JÚNIOR, 2002, p. 143).

O autor explica que o aluno anseia por capacidades e competências que o mercado requer, mas das quais ele não se vê possuidor. Portanto, aceita como suficiente e passa a exigir disciplinas que o treinem no uso de ferramentas e instrumentos que lhe proporcionem o domínio do "fazer" profissional. No entanto, segundo Almeida Júnior (2002), tendo em vista que as disciplinas curriculares não devem estar isoladas, bem como tomando consciência de que as técnicas e os instrumentos não são neutros, muito menos descontextualizados, é preciso resistir à ideia de uma elevada importância das atividades técnicas. Acrescentamos que as atividades técnicas são tão importantes quanto as relacionais e as de comunicação. Há que se distinguir, contudo, se são concebidas, desenvolvidas e voltadas à apropriação da informação e da cultura ou à mera "assimilação", termos que Perrotti e Pieruccini $(2008,2014)$ distinguem e necessitam ser devidamente considerados nos processos de formação.

A Classificação Brasileira de Ocupações (CBO) coloca o bibliotecário no rol dos profissionais da informação, descrevendo o que fazem e como atuam. Dessas atribuições, destacamos: facilitar o acesso e geração de conhecimento, realizar difusão cultural e desenvolver ações educativas (BRASIL, 2002a). Assim, na descrição da CBO sobre a atuação do profissional da informação fica claro, como ocorre no texto de Valentim (2000a), que o bibliotecário desenvolve tratamento de informação, sua organização, análise e síntese, facilitando o acesso e a geração de conhecimento e disseminando a informação, ou seja, ele faz mediação cultural, como parte intrínseca da profissão.

Compreendemos também a exposição de Ribeiro (2010), que considera a qualificação do bibliotecário como profissional da informação, no contexto da era digital, trouxe para o entendimento de sua formação profissional a necessidade do conhecimento e o uso das tecnologias digitais para recuperação e acesso à informação e como modelador de sistemas que ofereçam esses serviços, bem como a importância de expansão dos estudos sobre as necessidades informacionais.

No entanto, abordando sua condição de mediador cultural, podemos ampliar a reflexão de Milanesi (2002, p. 100) de que "entre uma necessidade de informação e sua satisfação existem fatores adversos em diversos graus [...] nem sempre são 
inerentes ao modo como as informações são produzidas, organizadas e disseminadas. Outros elementos [...] afetam sua distribuição e circulação". E, afetam, sobremaneira, as condições para a apropriação e o protagonismo cultural.

No caso da formação em Biblioteconomia e da Ciência da Informação, na medida em que docentes também sentem dificuldade em diferenciar ou especificar as atividades desenvolvidas por bibliotecários e gestores da informação, por exemplo, fica difícil "trabalhar" a identidade e a autoestima dos futuros profissionais bibliotecários. Possivelmente, essa diferenciação ajudaria 0 aluno a escolher conscientemente seu perfil, bem como o profissional a se reconhecer, ou se identificar, em relação ao mercado e a outros "profissionais da informação" (como são considerados). Uma situação dramática, apresentada na pesquisa de Walter (2008, p. 289), ilustra a questão. Um professor da área diz que:

Agora no universo acadêmico acho que é um balaio de gatos. As pessoas têm falado pela área muitas vezes não estão falando da posição da área, mas da posição delas. Se você conviver com as pessoas dos diversos cursos, são preocupações muito distintas, práticas muito distintas. As próprias inserções funcionais são muito diferenciadas, então um curso está na Faculdade de Economia, outro está na Faculdade de Comunicação, outro está na de Educação [...] no Departamento de Física e Matemática.

De outro lado, para Marchiori (2002), nomear o profissional de informação segundo sua instituição de atuação - embora as especialidades sejam também necessárias -, não resolve a questão, visto que o caráter genérico do profissional de informação seria uma imposição do próprio fenômeno da informação.

Segundo essa autora, na medida em que várias profissões se ocupam do processamento, fluxo e uso da informação, a questão não é estabelecer quem seja o melhor profissional ou qual pode monopolizar a atuação nas instituições, mas quem desenvolve:

Capacidade de gerar, em conjunto, solucões em suas demandas para clientes também singulares [o da biblioteca, o funcionário da empresa, o cliente da empresa...] em suas demandas e em ambientes onde a informação, se gerenciada de forma efetiva, ética e crítica, realmente possa definir espaços sociais, políticos, econômicos e culturais. (MARCHIORI, 2002). 
Para tanto, a formação profissional para o gerenciamento ético e crítico da informação, tanto quanto para a mediação cultural, é viabilizada junto à formação acadêmica. Além disso, as relações de trabalho se estabelecem cada vez menos entre chefes e subordinados, mas entre "mais e menos graduados", situação em que a educação formal é parte determinante da posição e ascendência de um profissional em uma organização (DRUCKER, 2001 e 2002).

Identificar perfis e competências desejáveis para os profissionais da informação - bibliotecários, arquivologistas e cientistas da informacão, dentre outros - que lidam com o público da "Sociedade da Informação e do Conhecimento", da "era digital" - é também uma questão, segundo Rodrigues (2005), pois: "pessoas passam mais tempo online realizando tarefas para si próprias, consideram-se satisfeitas com os resultados das suas próprias pesquisas na Web e vivem numa "infosfera" sem fronteiras nítidas entre trabalho, diversão e estudo".

As discussões levantadas num artigo de Souza (2006), que requisitou autores e pesquisas realizadas no campo científico da Ciência da Informação, convergem para o problema de identidade dos bibliotecários que se perguntam "quem somos". Para Souza (2006, p. 28):

Esse debate transmite, em várias circunstâncias, duas possíveis idéias: a) o bibliotecário tem uma completa ignorância de que sua imagem profissional é construída na interação social, por um processo de objetivação da realidade, assimilada como valor e então subjetivada e expressa como representação e, portanto, manifestando a percepção social que o próprio bibliotecário tem do valor do papel que exerce na sociedade e b) a sociedade não precisa da presença desse bibliotecário; ele é um impostor.

Para qualquer uma das duas ideias levantadas pelo autor, está em questão a função social do bibliotecário. Qual é a legitimação dada pela sociedade a esse profissional? Essa função mudou no percurso da história e das evoluções tecnológicas? A partir do que são criadas as dificuldades para identificá-la e caracterizá-la?

Com a implantação do curso de Gestão da Informação, no Departamento de Ciência da Informação da UFPE, pudemos perceber o temor e a insegurança de alunos de Biblioteconomia, bem como a animosidade ou receio de profissionais bibliotecários da região. 
Evidentemente, as razões para isso eram concretas, a partir da consideração de que bibliotecários já faziam o serviço de tratamento da informação para uso estratégico em empresas e, portanto, já detinham as técnicas e, de uma forma ou de outra, as tecnologias também. A questão, segundo o discurso, era que "só as empresas e o mercado não sabiam disso". Mas se já atuavam, como poderiam ser "invisíveis" para as empresas e para o mercado?

Face à tão intrincadas questões, seria solução apenas adequar o currículo da graduação em Biblioteconomia para as demandas resultantes dos avanços tecnológicos? Não nos parece que seja, considerando que as demandas não são apenas por conhecimento técnico e tecnológico, se falarmos de solução para "problemas de informação" seja no mundo corporativo ou na vida.

De fato, interessa e importa ao mercado e à economia que existam profissionais preparados e dedicados às soluções de organização, acesso e uso das informações estratégicas para a tomada de decisão empresarial. E, nesse sentido, uma graduação e um currículo para formar gestores de informação se configuram numa real resposta à demanda regional e global.

Mas o gestor da informação não é um novo perfil para o bibliotecário, nem um bibliotecário melhorado, nem melhor que bibliotecários. É um profissional necessário para uma demanda da sociedade (e do mercado), assim como o bibliotecário.

O bibliotecário pode ser visto como necessário e importante para a sociedade e para o mercado, mas não porque ele simplesmente diz que é necessário e importante e se ressente quando acha que não está sendo visto assim. Ele pode ser visto porque, verdadeiramente, é necessário e importante, embora enquanto grupo ou categoria atue de forma desfocada, provavelmente paralisado por sua crise identitária. Este depoimento extraído da tese de Walter (2008, p. 290) é impressionante:

A minha filha [...] faz psicologia [...] Então ela ficou lá quietinha assistindo os trabalhos enquanto eu estava esperando a minha hora [de apresentar o trabalho]. Depois ela falou assim, meu deus, porque que o bibliotecário tem assim tanta necessidade de falar assim eu sou importante, eu sou importante. Vocês não estão convencidos de que vocês são importantes? Você já viu um médico falar assim para a sociedade: eu sou importante viu?! eu sou importante [...] Porque eu nunca vi um pessoal que não acredita na sua importância! Ela é do terceiro ano de psicologia e fez essa leitura pelas apresentações dos trabalhos que estavam lá. 


\subsection{Bibliotecário: mediador cultural para quê?}

Em palestra proferida em 1990 e intitulada Por que e para que bibliotecário?, Almeida Júnior (1997, p. 103) enfatiza que o conceito do bibliotecário sobre ele mesmo não é muito diferente do da sociedade quando esta "responde" que o bibliotecário é "aquele que trabalha na biblioteca, com livros.". O autor entende a passividade atribuída a este profissional, dentre outros motivos, como resultado de uma reserva de mercado garantida por lei. Tal reserva, segundo ele, acaba gerando uma acomodação que contradiz o que apregoa o próprio bibliotecário, no exercício de sua atividade, quando convoca o usuário a atualizar-se.

Almeida Júnior (1997) conclui que os bibliotecários estão sem objetivos definidos, não sabem sua função social e o sentido de existir como profissional: "por causa disso, buscamos, mesmo sem o saber, a nossa razão de ser dentro de nós mesmos, dentro de nossas técnicas, serviços, dentro da biblioteca" (ALMEIDA JúNIOR, 1997, p. 104). A Figura 7 ilustra parte desse "drama" do bibliotecário.

Figura 7: O que os bibliotecários fazem?

\section{CROCK e os legionários}

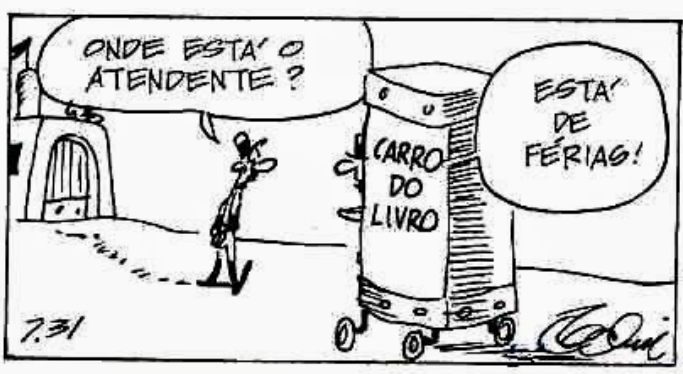

Rechin \& Wilder

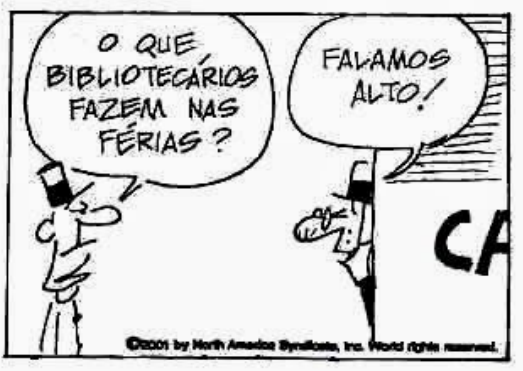

Fonte: Valdez, T. Tirinhas de quadrinhos, charge, imagem, humor de biblioteca, bibliotecário, leitura e livros ${ }^{13}$.

Mas é possível que do ano de 1997, data do texto de Almeida Júnior, para o ano de 2016, o conceito da sociedade sobre o bibliotecário tenha mudado diante de novos slogans exaltados pelos "profissionais da informação" como, por exemplo, o da disseminação e do acesso à informação. Para ilustrar nossa reflexão, recorremos

\footnotetext{
${ }^{13}$ Disponível em: http://1.bp.blogspot.com/1qaonyd5XCE/U78zNM4pDCI/AAAAAAAADic/7DWcetYpw7k/s1600/12_10_10.jpg. Acesso em: jun. 2015.
} 
a uma notícia da agência de notícias espanhola EFE, de 2014, que é pertinente à questão: qual a finalidade do bibliotecário? O trecho da notícia que se segue tem a manchete: Suposto bibliotecário da Al Qaeda nega marcação de alvos na Internet.

Al Malaki foi detido em Valência em 27 de março de 2012 e o apelido de "bibliotecário da Al Qaeda" se deve a uma divulgação de manuais e enciclopédias de treino terrorista [...] Seu trabalho consistia em armazenar em dispositivos informáticos uma grande quantidade de documentos sobre a jihad, discursos de líderes terroristas, manuais de armas e de fabricação de explosivos que mais tarde postava na rede [...]. (SUPOSTO..., 2014)

Embora "armazenar", organizar, "divulgar" ou "disseminar" documentos sejam também atividades que os bibliotecários realizam, e se alguém realiza essas atividades é logo confundido com o profissional bibliotecário (como no caso da reportagem citada acima), a necessidade social da profissão não se explica somente por seus procedimentos técnicos, conforme o exemplo acima.

Nesse sentido, torna-se necessário também distinguir a "serventia" social da atividade, dos seus procedimentos técnicos e das ferramentas da profissão. Técnicas e utilização de recursos são instrumentos para o desempenho da profissão e não a "razão de ser" da profissão. Técnicas e procedimentos para organizar e disseminar, tanto a informação quanto os demais saberes e produtos culturais, são ferramentas utilizadas para a finalidade de responder à demanda por apropriação e por protagonismo cultural, tendo em vista a construção de espaços que permitam o viver juntos. A técnica é, nesse sentido, avaliada segundo critérios axiológicos e deontológicos, não é uma mera "função", pois nem sempre o "funcional" é o "moral".

Os manifestos da IFLA/Unesco que analisamos apontam para essa demanda "humanística" quando falam de missões-chave e qualificações do profissional da biblioteca, como as de apoiar a autoformação e assegurar meios para que as pessoas "evoluam" de forma criativa, bem como fomentar o diálogo intercultural e criar ambientes de produção de informação e de conhecimento, de liberdade intelectual e de fruição. Portanto, criar condições para a apropriação e o protagonismo cultural, tendo em vista a possibilidade de um mundo "comum" partilhado.

Ortega y Gasset (2006, p. 3) diz, no seu discurso Missão do bibliotecário, proferido em 1935, que a palavra missão significa "aquilo que um homem deve 
fazer" e que as profissões são um tipo de atividade humana de que a sociedade necessita. Mas para determinar a "missão do bibliotecário" é necessário partir da necessidade social a que serve a profissão e não dos gostos e conveniências do "homem" que a exerce. Além disso, considera que a necessidade social não é fixa, mas histórica.

Mas se o bibliotecário é, intrinsecamente, um mediador cultural, levando-se em conta a demanda social de apropriação e de protagonismo cultural, os conhecimentos, as técnicas, as ferramentas, as competências da mediação cultural para o desempenho dessa profissão, necessitam ser construídos e desenvolvidos na sua formação. E, assim, o profissional bibliotecário serve a sociedade que os legitima, nos termos de Ortega y Gasset (2006). Além disso:

Há um novo sentido de educação visto como processo de motivar e seduzir para o desejo contínuo do aprender [...] Educar para a inserção e participação social, propiciando o desenvolvimento de competências e saberes que revertam aos propósitos do sujeito e da sociedade, imputando-lhes um sentido existencial. (BARRETO, 2005).

O ensaio publicado na web, pela professora Eliane Mey (2009), intitulado a Biblioteconomia envergonhada, provoca o questionamento sobre razões que contribuem para que o profissional bibliotecário contemporâneo, no Brasil, esteja numa condição de "invisibilidade" e baixa autoestima.

A autora explica que uma busca pela etimologia da palavra biblioteconomia nos fará concluir que se trata da aplicação e administração das normas, regras e leis para os lugares de guarda dos registros de conhecimento, o que pode nos levar ao erro de ignorar a característica mutante dessas normas, regras e leis de acordo com a dinâmica cultural e tecnológica e, portanto, a "multidisciplinaridade" biblioteconômica.

O trabalho de Biblioteconomia, que remonta à Antiguidade, bem como à história do surgimento das bibliotecas, já nos é bem conhecido, ou acessível, para que possamos entender, numa linha do tempo, as demandas por esse profissional, a necessidade social de suas atividades e as mudanças que trouxeram inovações para o seu saber fazer. Mas será que as mudanças e os avanços tecnológicos modificaram o essencial ou o intrínseco dessa profissão ou nunca identificamos o que corporifica a profissão de bibliotecário, bem como o fim de suas atividades? A 
Figura 8 nos faz questionar se as tecnologias e os suportes definem uma "evolução" do bibliotecário.

Figura 8: Tecnologias e suportes definem uma "evolução" do bibliotecário?

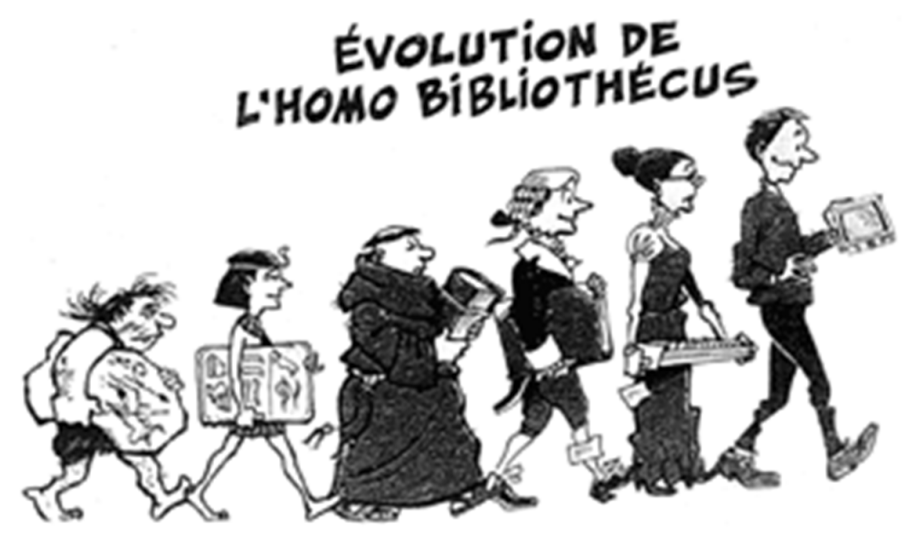

Fonte: Valdez, T. Tirinhas de quadrinhos, charge, imagem, humor de biblioteca, bibliotecário, leitura e livros ${ }^{14}$.

Afirmamos que o bibliotecário é um mediador cultural, e a finalidade da profissão é a apropriação e o protagonismo cultural. Portanto, segundo tal perspectiva, concordamos com Dufrêne e Gellereau (2004a) para quem os objetivos de utilização da expressão mediação cultural são múltiplos:

[...] para os profissionais, objetivos de reconhecimento de uma atividade que não se situa mais somente no domínio da conservação de obras do patrimônio mas mais geralmente na orientação tomada pelas instituições culturais enquanto são voltadas para o público; para os políticos, justificação de políticas culturais cuja missão seria essencialmente social, corretora de desigualdades; enfim, para os pesquisadores, tentativa de conhecer e de compreender diferentes formas de difusão da cultura e os fins aos quais respondem e pensar programas que permitem aos futuros profissionais da cultura dispor de saber e referências necessárias (DUFRÊNE; GALLEREAU, 2004a).

Os textos orientadores - as diretrizes - ao destacarem a dimensão pedagógica da profissão de bibliotecário mostram-no como um mediador cultural em uma de suas facetas. No entanto, ele é apresentando como aquele que planeja e regula, visando à aprendizagem de saberes e produtos culturais, como a

\footnotetext{
${ }^{14}$ Disponível em: http://1.bp.blogspot.com/1qaonyd5XCE/U78zNM4pDCI/AAAAAAAADic/7DWcetYpw7k/s1600/12_10_10.jpg. Acesso em: dez. 2015.
} 
informação, estabelecidos. Nesse sentido, é um educador, obviamente. Porém, entendemos que esse educador é prescrito como aquele que deve desenvolver competências profissionais para o controle dos fluxos dos saberes e bens simbólicos, visando a difusão e o acesso cultural e não a apropriação cultural.

Também uma dimensão comunicativa da mediação cultural pode ser vista nos documentos orientadores quando apresentam o bibliotecário como um tradutor e um intermediário sensível à interculturalidade. Contudo, embora esteja subentendido que ser um intermediário ativo signifique atuar como e com protagonistas, a finalidade de sua intervenção precisa ser clarificada para compreendermos se o mediador cultural bibliotecário está respondendo à demanda social da profissão. Apenas traduzir os saberes, objetos e dispositivos culturais para um público coloca esse público na condição de consumidor de cultura e não na de protagonista cultural.

Portanto, somos levados a questionar tanto o bibliotecário como um controlador como quanto difusor cultural, se considerarmos objetivos de apropriação cultural. O bibliotecário reconhecido e formado como um mediador cultural, comprometido com a apropriação e o protagonismo culturais, é um desafio emergente e aponta para a reconfiguração de textos orientadores e diretrizes para a formação em Biblioteconomia.

As propostas de formação em mediação cultural que foram analisadas neste trabalho apresentam o mediador cultural, ele próprio, como um protagonista cultural, que atua negociando sentidos, realizando tarefas e propondo ações que viabilizam a apropriação e o protagonismo cultural dele e de indivíduos, grupos e coletividades. Seus fazeres compreendem planejamento e gerenciamento de projetos culturais, baseados na dialogia com outros protagonistas, para que se estabeleça a comunicabilidade entre acervos, tangíveis e intangíveis, repertórios humanos e os protagonistas da cultura. Seus saberes, como vimos nos programas de formação em mediação cultural, incluem e focalizam conhecimentos em Ciências Humanas, Sociais, da Informação e da Comunicação, Sociologia e História da cultura; Linguagens artísticas; Políticas, Economia e Organização da cultura; Gerenciamento de projetos, bem como teorias e aplicações de tecnologias de Organização da informação e da memória, dentre outros.

Temos, portanto, o desafio de reavaliar e requalificar as propostas de 
formação de bibliotecários se entendermos que ele é um mediador cultural. No entanto, o desafio que precede todos os outros é o de refletir, discutir, teorizar e explicitar os conceitos de mediação cultural e de apropriação cultural na Biblioteconomia e no campo da Ciência da Informação, utilizando processos, ferramentas, métodos próprios e específicos da área. Trata-se, pois, de estar atento tanto às mediações "explícitas" como às "implícitas", referidas por Almeida Júnior (2009). Desse modo, talvez seja possível compatibilizar, nas formações, demanda social e legitimação profissional do bibliotecário como mediador cultural.

Além disso, o ambiente da teorização é fundamental no desenvolvimento de competências para mediar cultura. Admitimos, conforme Otaviano Pereira (2003), que teorizar é também ação inerente à condição humana. $O$ mediador cultural, pensando a realidade, interfere e participa de transformações. O mediador cultural que teoriza é, ao mesmo tempo, sujeito e objeto do conhecimento, levado a negociar, diante de contextos culturais e ideológicos, com indivíduos, grupos e coletividades - com protagonistas culturais. 


\section{CONSIDERAÇÕES FINAIS}

A construção desta tese se deu a partir de inquietações geradas pela experimentação da formação em Biblioteconomia como discente e posteriormente como docente. $\mathrm{O}$ envolvimento com projetos de extensão voltados ao letramento digital e à mediação de leitura fez com que a visão da profissão se alargasse, levando à compreensão da necessidade da abordagem da mediação cultural como questão essencial aos saberes e fazeres das atividades do profissional bibliotecário.

Inquietante era perceber o desconforto dos profissionais, também de discentes e docentes, ao precisarem se definir e identificar nos seus locais de atuação - para a sociedade -, especialmente a cada incorporação de tecnologias, que, aliás, passam a ser realidade de qualquer profissional, independentemente da área de atuação e em toda parte. Observávamos que tais incorporações acentuavam a crise de identidade e os questionamentos sobre a função e a "missão" do bibliotecário: se controlador dos fluxos e dos usos da informação ou difusor de informação para assimilação e consumo de determinados públicos. Mas não compreendíamos as razões de tal situação.

Portanto, partimos do pressuposto de que o bibliotecário é um mediador cultural - serve à sociedade quando foca suas atividades na demanda por apropriação cultural. Mas esse é um entendimento que tem se apresentado de forma insuficiente e confusa desde sua formação. Por outro lado, buscamos levantar um debate sobre a centralidade da cultura na contemporaneidade e a importância de aprofundá-lo inclusive no campo da Ciência da Informação e na Biblioteconomia.

Consideramos a mediação cultural, tanto em sua dimensão implícita como na explícita, como atividade intrínseca do fazer do bibliotecário: dá-se a partir da seleção e organização dos acervos e fluxos da informação até as práticas de atendimento, interação e relação com o público. No entanto, é preciso que o trabalho não tenha o "acesso à informação" como finalidade única, mas a apropriação e o protagonismo cultural de indivíduos, grupos e coletividades. Por isso, e tendo em vista que a informação é um produto cultural, decorrente da atuação intencional de protagonistas, à Ciência da Informação cabe dar o "peso epistemológico merecido", 
usando palavras de Hall (1997), e necessário aos conceitos de cultura e de mediação cultural.

Além disso, a Ciência da Informação, que Wersig (1993) considera como pósmoderna por estar voltada à resolução de problemas, pode se debruçar, por exemplo, sobre os problemas gerados pela "lógica cultural" contemporânea e elaborar teorias que deem suporte a uma mediação para a apropriação, protagonismo e empoderamento cultural. Consideramos, como Santos (1987), que o pensamento científico deve nortear o estudo da sociedade no sentido de transformála e não apenas compreendê-la.

A mediação cultural, concordamos com Davallon (2007), compreende uma dimensão teórica que é a dos saberes que remetem à mediação da informação e à Sociologia e à Semiótica da comunicação, como também da Política. Nesse sentido, caracteriza-se uma demanda por um arcabouço teórico da mediação cultural na Ciência da Informação e na Biblioteconomia, com efeito na formação do mediador cultural que protagonize, junto a um público, ações que modifiquem e ressignifiquem a cultura e a si próprio, por meio da negociação de sentidos.

Sendo assim, somos desafiados a pensar a formação do mediador cultural bibliotecário com atenção às concepções de cultura, às políticas culturais, às regulações da cultura e às hegemonias, nos termos colocados por Dufrêne e Gellereau (2004b). Ou seja, uma formação que inclua a pesquisa e as práticas das dimensões sociopolítica, pedagógica, comunicativa e emancipatória da mediação cultural.

A formação do mediador cultural bibliotecário como profissional que domina as lógicas culturais, comunicativas, e dos dispositivos culturais ofertados à sociedade, além de mediar os processos de aprendizagem informacional de que tratam Perrotti e Pieruccini (2008), aponta para a demanda da apropriação cultural.

A apropriação cultural de indivíduos, grupos e coletividades - como o movimento que torna próprios saberes e objetos construídos, transformados e significados nas interações sociais, em que são elaborados e negociados sentidos entendemos como a finalidade social do mediador cultural bibliotecário. Portanto, sua formação não prescinde de subsídios para que o mesmo desenvolva competências para a negociação com os protagonistas da cultura - que não apenas reproduzam ou consumam, mas criam e recriam a cultura e seus significados. 
Por meio do estudo de Souza (2009) sobre a formação no século XX, pudemos perceber que a relevância do cultural no contexto das relações de informação, apropriação e empoderamento cultural e sociopolítico do público foi pouco considerada na formação e no trabalho dos profissionais bibliotecários nesse período. Isso, para nós, só contribuiu para desvirtuar ainda mais a razão maior de ser do bibliotecário, advinda de objetivos políticos e sociais de apropriação e protagonismo cultural.

Olhando para uma outra realidade, em busca de uma visão além dos caminhos percorridos no Brasil para a formação de bibliotecários, vimos que, na França, também durante o século XX, pelas ponderações de Renoult (2009), as técnicas se tornaram as estruturadoras da identidade profissional, em detrimento da reflexão crítica necessária à inovação. E, assim, segundo ele, gerou-se a necessidade de formação universitária na França. Mas Bettant (2012) explica que houve uma geração que militou pelo "ensinar e reensinar" mais que conservar, pedindo que a formação desse ênfase a este aspecto da relação com o público e em benefício da sociedade.

Para discutir a visão do bibliotecário como mediador cultural, recorremos a documentos que consideramos orientadores - diretrizes - para a formação no Brasil. Selecionamos a Lei n 4.084/1962, de 30 de Junho de 1962, que dispõe sobre a profissão de bibliotecário e regula seu exercício; as Diretrizes curriculares para os cursos de Biblioteconomia do Ministério da Educação; e os Manifestos da IFLA/Unesco sobre bibliotecas públicas, da biblioteca escolar e o da biblioteca multicultural. Verificamos que esses documentos não fazem uso da expressão mediação cultural e percebemos, sobretudo, que restringem o entendimento de mediação cultural, por colocá-la na categoria de serviço e distanciá-la da categoria de relação de troca e negociação de sentidos.

Consideramos, portanto, que documentos orientadores não colocam de forma clara o bibliotecário como mediador cultural, como um "negociador cultural" (OLIVEIRA, 2014), mas um educador-difusor que oferta seus serviços para a assimilação e não para a apropriação e o protagonismo cultural. Nesse sentido, identificamos o desafio da reconfiguração de textos orientadores e diretrizes para a formação em Biblioteconomia.

Também nos pareceu pertinente buscar o entendimento de como é definido e pode ser formado o mediador cultural, por meio de propostas de formação ofertadas 
no Brasil e na França, país escolhido por possuir expertise reconhecida internacionalmente em formações em mediação cultural. Tal busca visou clarificar o entendimento de que o bibliotecário é mediador cultural e, ao mesmo tempo, identificador de desafios para então formar o bibliotecário como mediador cultural no Brasil.

Com base nas propostas de formação em mediação cultural, analisadas neste trabalho, é possível definir o mediador cultural como um ator privilegiado dos processos de negociação de sentidos. Ele propõe ações, realiza tarefas e atua para a apropriação e o protagonismo cultural de indivíduos, grupos e coletividades, baseados na dialogia, na interlocução entre e com diferentes públicos. Assim, somos desafiados a reavaliar e requalificar as propostas de formação de bibliotecários. Entendemos que a formação universitária do bibliotecário mediador cultural pode apresentar as condições "ideais" para incluir, pensar, melhorar ou transformar práticas desse profissional.

Consideramos, principalmente, o desafio de instaurar balizadores da construção de propostas de formação que visem 0 desenvolvimento das competências de um mediador cultural para atender à demanda social e legitimar o bibliotecário. Os balizadores precisam ser construídos com a reflexão, discussão e teorização da mediação cultural na área de Biblioteconomia, fundamentada em princípios gerais oferecidos pela Ciência da Informação que tratam das questões envolvendo a apropriação social da informação e o protagonismo cultural. Objeto (mediação) e objetivo (apropriação cultural) se encontram, nessa perspectiva, interagem rompendo a dicotomia erudição/técnica que marcou a evolução da formação em Biblioteconomia, no país.

O problema erudição ou humanismo versus técnica na formação é um falso dualismo, já que ao se alimentarem mutuamente, tais categorias instituem um paradigma "complexo" (MORIN, 2005) capaz de abrir portas de importância fundamentais aos avanços das ações da mediação intrínseca do fazer profissional dos bibliotecários. Com isso, Biblioteconomia e bibliotecários poderão entrar em conexão com a sociedade, reconhecendo-a e sendo por ela reconhecidos. Refazer a formação é, pois, mais que alterar currículos: é refazer modos de pensá-la, integrando saberes e fazeres plurais num todo orgânico e coerente, em vista da construção de condições que permitam equacionar demandas socioculturais e profissionais de criação e protagonismo cultural. 
Desse modo, talvez, possamos vislumbrar a emergência de profissionais bibliotecários que não vivam mais frustrados entre a "técnica" e a "cultura", a "especialização" e o "eruditismo", como desde há muito tempo desejamos na área, mas que continuamos ainda a perseguir como verdadeira utopia. Esta, contudo, pode amadurecer e se realizar. 


\section{REFERÊNCIAS}

ALMEIDA JÚNIOR, O. F. de. Mediação da informação e múltiplas linguagens. Pesquisa Brasileira em Ciência da Informação, Brasília, v. 2, n.1, p. 89-103, jan./dez. 2009. Disponível em: <http://inseer.ibict.br/ancib/index.php/tpbci/article/view/17/39> Acesso em: 09 jan. 2014.

ALMEIDA JUNIOR, O. F. Formação, formatação: profissionais da informação produzidos em série. In: VALENTIM, M. L. P. (Org.). Formação do profissional da informação. São Paulo: Polis, 2002. p. 133-148.

ALMEIDA JÚNIOR, O. F. de. Sociedade e Biblioteconomia. São Paulo: Pólis, 1997.

ANNONI, Danielle. Os sessenta anos da Declaração Universal dos Direitos Humanos das Nações Unidas: contribuições e perspectivas. Revista Direito, Estado e Sociedade, n. 33, p. 19-35, jul./dez., 2008, Rio de Janeiro: PUC-Rio, 2008. Disponível em: http://www.jur.pucrio.br/revistades/index.php/revistades/article/view/236 . Acesso em: 23 jun. 2012.

ASSOCIAÇÃO BRASILEIRA DE EDUCAÇÃO EM CIÊNCIA DA INFORMAÇÃO. Avaliação do Processo Formativo na Área de Biblioteconomia / Ciência da Informação: documento referencial São Paulo: ABECIN, 2002.

ASSOCIAÇÃO BRASILEIRA DE EDUCAÇÃO EM CIÊNCIA DA INFORMAÇÃO. Projeto pedagógico e avaliação da graduação: referências para a renovação e ressignificação do ensino em Biblioteconomia/Ciência da Informação. São Paulo, 2001. Disponível em: <http://www.abecin.org>. Acesso em: 20 out. 2014.

BARRETO, A. M. O fator humano e o desenvolvimento de competências nas unidades de informação. Perspectiva em Ciência da Informação. Belo Horizonte, v.10, n.2, p.132-139, jul./dez., 2005.

BATTLES, M. A conturbada história das bibliotecas. São Paulo: Planeta, 2003.

BENJAMIN, W. A obra de arte na era de sua reprodutibilidade técnica. In: Magia e técnica, arte e política. 3. ed. São Paulo: Brasiliense, 1987.

BETTANT, A. Histoire de la formation du bibliothécaire: du DTB à l'ENSB (19321963). [en ligne]. Mémoire d'étude: diplôme de conservateur de bibliothèque; janvier 2012.

BRASIL. Lei no 4.084/1962, de 30 de junho de 1962. Dispõe sobre a profissão de bibliotecário e regula seu exercício. Diário Oficial [da] República Federativa do Brasil, Brasília/DF, 2 de julho de 1962.

BRASIL. Ministério da Educação. Conselho Nacional da Educação. Homologação do Parecer CNE/CES n. 492/20001. Brasília, DF, 04 de julho de 2001 a. 
BRASIL. Ministério da Educação. Diretrizes Curriculares Nacionais dos Cursos de: Filosofia, História, Geografia, Serviço Social, Comunicação Social, Ciências Sociais, Letras, Biblioteconomia, Arquivologia e Museologia. Brasília, DF, $2001 \mathrm{~b}$.

BRASIL. Ministério do Trabalho. Classificação brasileira de ocupações. Brasília/DF, 2002a. Disponível em: http://www.mtecbo.gov.br/index.htm. Acesso em: 30 abr. 2011.

BRASIL. Resolução n. 19, de 13 de março de 2002. Estabelece as Diretrizes Curriculares para os cursos de Biblioteconomia. Diário Oficial da União, Brasília/DF, de 9 abril de 2002b. Seção 1, p. 34.

BURKE, P. Problemas causados por Gutenberg: a explosão da informação nos primórdios da Europa moderna. Estudos Avançados, n. 44, v. 16, p.173-185, jan./abr. 2002.

BUSH, V. Como pensamos. In: RIBEIRO, A. E., COSCARELLI, C. V. (Org.). Hipertexto em tradução. Belo Horizonte: FALE/UFMG, 2007. p. 7-32.

CAMPELLO, B. A competência informacional na educação para o século 21. In: Biblioteca escolar: temas para uma prática pedagógica. Belo Horizonte: Autêntica, 2002.

CAMPELLO, B. O movimento da competência informacional: uma perspectiva para o letramento informacional. Ciência da Informação, [S.I.], v. 32, n. 3, fev. 2003.

Disponível em: <http://revista.ibict.br/ciinf/index.php/ciinf/article/view/26/21>. Acesso em: 20 ago. 2015.

CANCLINI, N. G. Culturas híbridas: estratégias para entrar e sair da Modernidade. 4. ed. São Paulo: EDUSP, 2008.

CANCLINI, N. G. Diferentes, desiguais e desconectados. 3. ed. Rio de Janeiro: Editora UFRJ, 2009.

CAPURRO, R. Ética para provedores e usuários da informação. In: KOLB, A.; ESTERBAUER, R.; RUCKENBAUER, H.-W. (Orgs.). Ciberética: responsabilidade em um mundo interligado pela rede digital. São Paulo: Loyola, 2001.

CAPURRO, R. Epistemologia e Ciência da informação. In: ENCONTRO NACIONAL DE PESQUISA EM CIÊNCIA DA INFORMAÇÃO, 5., Belo Horizonte, 2003. Anais... Belo Horizonte: UFMG, 2003.

CASTRO, C. A. História da Biblioteconomia brasileira. Brasília: Thesaurus Editora, 2000.

CHARTIER, A.-M.; HÉBRARD, J. Os discursos dos bibliotecários. In: Discursos sobre a leitura: 1880-1980. São Paulo: Ática, 1995.

COELHO NETTO, J. T. Dicionário crítico de políticas culturais. Cultura e imaginário. 3. ed. São Paulo: FAPESP; lluminuras, 2004. 
CORONA, B., Sarah y PÉREZ DANIEL, M. R. Entre voces - entre culturas: la autoría dialógica hacia la participación en el espacio público". In: Interculturalidades en educación.. Centro de Cooperación regional para la educación de adultos en América Latina y el Caribe, Patzcuaro, México. p.15-19 sep./dic. 2009 (Decisio, n. 24).

COSTA, L. F. Profissionalização da organização da cultura no Brasil: uma análise da formação em produção, gestão e políticas culturais. 2011. 239f. Tese (Doutorado) Universidade Federal da Bahia, Salvador, 2011.

CRESWELL, J. W. Projeto de pesquisa: métodos qualitativo, quantitativo e misto, Porto Alegre: Artmed, 2007.

CÚPULA MUNDIAL DA SOCIEDADE DA INFORMAÇÃO. Declaración de Principios Construir la Sociedad de la Información: un desafío global para el nuevo milenio. 2004. Disponível em. <http://www.itu.int/net/wsis/docs/geneva/official/dop-es.html>. Acesso em: dez. 2015.

DAVALLON, J. A mediação: a comunicação em processo? Prisma - Revista de Ciência da Informação e da Comunicação, n. 4, p. 03-36, jun. 2007. Disponível em: $<$ http://prisma.cetac.up.pt/A_mediação_a_comunicação_em_processo.pdf>. Acesso em 06 ago. 2010.

DRUCKER, P. F. A administração na próxima sociedade. São Paulo: Nobel, 2002.

DRUCKER, P. F. O melhor de Peter Drucker: o homem. São Paulo: Novel, 2001.

DUDZIAK, E. A. A information literacy e o papel educacional das bibliotecas.

2001. Dissertação (Mestrado em Ciência da Informação) - Escola de Comunicações e Artes, Universidade de São Paulo. São Paulo, 2001.

DUFRÊNE, B., GELLEREAU, M. A mediação cultural: objetivos profissionais e políticos. Hermès, n.38, p.199-206, 2004a. Tradução livre de Juliana Maria de Siqueira. Texto não publicado. Texto não paginado.

DUFRÊNE, B., GELLEREAU, M. La médiation culturelle: enjeux professionnels et politiques. Hermès, n.38, p.199-206, 2004b.

ECO, U. Como se faz uma tese. 23. ed. São Paulo: Perspectiva, 2010.

ESCARPIT, R. Sociologia da literatura. Lisboa: Arcádia, 1969.

FREIRE, P. Pedagogia do oprimido. 42. ed. Rio de Janeiro: Paz e Terra, 2005.

GILROY, P. Entre campos: nações, culturas e o fascínio da raça. São Paulo: Annablume, 2007.

GONZÁLEZ DE GÓMEZ, M. N. Dos estudos sociais da informação aos estudos do social desde o ponto de vista da informação. In: AQUINO, M. A. (Org.). O campo da Ciência da Informação: gênese, conexões e especificidades, João Pessoa: UFPB, 2002. 
HALL, S. A centralidade da cultura: notas sobre as revoluções culturais do nosso tempo. 1997. Disponível em:

$<\mathrm{http}: / /$ www.educacaoonline.pro.br/art_a_centralidade_da_cultura.asp?f_id_artigo=4 50>. Acesso em: 05 jul. 2012.

HALL, S. A identidade cultural na pós-modernidade. 11. ed. Rio de Janeiro: DP\&A, 2006.

IFLA. Manifiesto IFLA por la Biblioteca multicultural. 2006. Disponível em: $<$ http://archive. ifla.org/VIl/s32/pub/MulticulturalLibraryManifesto-es.pdf> Acesso em: 20 ago. 2011.

IFLA/UNESCO. Manifesto IFLA/UNESCO para biblioteca escolar. IFLA, 1999.

IFLA/UNESCO. Manifesto IFLA/UNESCO sobrebibliotecas públicas. IFLA, 1994.

IFLA/UNESCO. Manifiesto IFLA / UNESCO por la biblioteca multicultural. IFLA, 2009.

JAMESON, F. Pós-modernismo e sociedade de consumo. In: JAMESON, F. A virada cultural: reflexões sobre o pós-modernismo. Rio de Janeiro: Civilização Brasileira, 2006. p. 15-44.

LATOUR, B. Redes que a razão desconhece: laboratórios, bibliotecas, coleção. In: BARATIN, Marc; JACOB, Christian O poder das bibliotecas: a memoria dos livros no ocidente. 3. ed. Rio de Janeiro: Ed. UFRJ, 2008.

LE COADIC, Y.-F. A Ciência da Informação. 2. ed. Brasília: Briquet de Lemos, 2004.

MARCHIORI, P. Z. A Ciência e a gestão da informação: compatibilidades no espaço profissional. Revista Ciência da Informação, Brasília, v. 31, n. 2, p. 72-79, maio/ago. 2002.

MEY, E. A biblioteconomia envergonhada. 2009. Disponível em: http://www.ofaj.com.br/textos_conteudo.php?cod=264>. Acesso em: 18 jan 2014.

MILANESI, L. Biblioteca. São Paulo: Ateliê, 2002.

MODESTO, J. F. Não bata cabeça, use-a com criatividade na biblioteca. 2007. Disponível em: http://www.ofaj.com.br/textos_conteudo.php?cod=156>. Acesso em: 18 jan 2014.

MORIN, E. Educação planetária: conferência na Universidade São Marcos, São Paulo, Brasil, 2005. Disponível em: http://edgarmorin.org.br/textos.php?tx=30. Acesso em: 05 ago. 2012.

OLIVEIRA, A. L. A negociação cultural: novas referências para a mediação e a apropriação da cultura escrita. 2014. 220f. Tese (Doutorado em Ciência da Informação) - Escola de Comunicações e Artes, Universidade de São Paulo, São Paulo, 2014. 
ONU. Declaração Universal dos Direitos Humanos. 1948. Disponível em: $<$ http://portal.mj.gov.br/sedh/ct/legis_intern/ddh_bib_inter_universal.htm> Acesso em: 20 ago. 2011.

ORTEGA Y GASSET, J. Missão do Bibliotecário. Brasília: Briquet de Lemos, 2006.

PERAYA, D. O ciberespaço: um dispositivo de comunicação e de formação midiatizada. In: ALAVA, S. (Org.) Ciberespaço e formações abertas: rumo a novas práticas educacionais. Porto Alegre: Artmed, 2002. p. 25-52.

PEREIRA, O. O que é teoria. São Paulo: Brasiliense, 2003.

PERROTTI, E. A aventura de conhecer: proposta pedagógica. Boletim Salto para o Futuro, Rio de Janeiro, v. 18, p. 3-13, 2008. Disponível em: $<$ http://www.tvbrasil.org.br/fotos/salto/series/173714Aventura.pdf> Acesso em: 05 jul. 2012.

PERROTTI, E.; PIERUCCINI, I. Infoeducação: saberes e fazeres da contemporaneidade. In: LARA, M. L. G, FUJINO, A. NORONHA, D. P. (Org.) Informação e contemporaneidade: perspectivas. Recife: Néctar, 2008.p. 46-97. Disponível em: $<$ http://www.pos.eca.usp.br/sites/default/files/file/ciencialnformacao/informacaoConte mporaniedade.pdf>. Acesso: 05 jul. 2012.

PERROTTI, E; PIERUCCINI, I. A mediação cultural como categoria autônoma. Informação \& Informação, [S.I.], v. 19, n. 2, p. 01-22, out. 2014. Disponível em: <http://www.uel.br/revistas/wrevojs246/index.php/informacao/article/view/19992>. Acesso em: 03 nov. 2015.

PIERUCCINI, I. A ordem informacional dialógica: estudo sobre a busca de informação em Educação. 2004. 194f. Tese (Doutorado) - Escola de Comunicações e Artes, Universidade de São Paulo, São Paulo, 2004.

RAYWARD, W.B. The origins of Information Science and the International Institute of Bibliography/International federation for Information and Documentation (FID). Journal of the American Society for Information Science, v. 48, n. 4, p. 289-300, 1997.

RENOULT, D. Formation professionnelle des bibliothécaires: un regard rétrospectif et prospectif. Formation professionnelle des bibliothécaires. Bulletin des bibliothèques de France, $\mathrm{n}^{\circ} 5$, 2009. Disponible sur le Web : <http://bbf.enssib.fr/consulter/bbf-2009-05-0063-001 Acesso em: 20 abr. 2015]

RIBEIRO, F. Da mediação passiva à mediação pós-custodial: o papel da Ciência da Informação na sociedade em rede. Informação \& Sociedade. João Pessoa, v.20, n.1, p. 63-70, jan./abr. 2010. Disponível em: <http://www.ies.ufpb.br/ojs2/index.php/ies/article/view/4440/3420 >. Acesso em: 21 jun. 2010.

RODRIGUES, E. Os bibliotecários na sociedade da informação: (r)evolução de perfis e competências. In: Conferência "Os profissionais da informação em contexto europeu", 2005, Lisboa. RepositoriUM - repositório institucional da Universidade de 
Minho. Disponível em: <https://repositorium.sdum.uminho.pt/handle/1822/3480>. Acesso em: 23 out. 2007.

RUSSELL, B. O conhecimento inútil. In: Sextante, 2002. p.36-46. .O elogio ao ócio. Rio de Janeiro:

RUSSO, L. G. M. A Biblioteconomia brasileira: Rio de Janeiro: INL, 1966. 357p.

SANTOS, B. S. Um discurso sobre as ciências. Porto: Afrontamento, 1987.

SARACEVIC, T. Ciência da Informação: origem, evolução e relações. Perspectiva em Ciência da Informação, Belo Horizonte, v. 1, n. 1, p. 41-62, jan./jun. 1996.

SERFATY-GARZON, P. Apropriação. In : Dictionnaire critique de l'habitation et du logement. Paris: Armand Colin, 2003. p. 27-30.

SHERA, J. Epistemologia social, semântica geral e biblioteconomia. Ciência da Informação, v.6, n.1, p.9-12, 1977.

SINGLY, F. A apropriação da herança cultural. Educação e Realidade, Belo Horizonte, v. 34, n. 1, p. 9-32, jan./abr. 2009.

SMIT, J. W.; TÁLAMO, M. F. Ciência da Informação: uma ciência moderna ou pósmoderna? In: LARA, M. L. G, FUJINO, A. NORONHA, D. P. (Org.) Informação e contemporaneidade: perspectivas. Recife: Néctar, 2008. p. 46-97. Disponível em: $<$ http://www.pos.eca.usp.br/sites/default/files/file/ciencialnformacao/informacaoConte mporaniedade.pdf>. Acesso: 05 jul, 2012.

SOARES, M. Novas práticas de leitura e escrita: letramento na cibercultura. Educ. Soc. [online]. v. 23, n. 81, p. 143-160, 2002,. Disponível em:< http://www.scielo.br/scielo.php?script=sci_arttext\&pid=S010173302002008100008 >. Acesso em: 28 ago. 2014.

SOUZA, F. C. de. A formação acadêmica de bibliotecários e cientistas da informação e sua visibilidade, identidade e reconhecimento social no Brasil. Informação \& Sociedade: Estudos, João Pessoa, v. 16, n. 1, p. 32-46, jan./jun. 2006.

SOUZA, F. C. de. O ensino de Biblioteconomia no contexto brasileiro: século XX. 2. Ed. Florianópolis: UFSC, 2009.

SUPOSTO bibliotecário da Al Qaeda nega marcação de alvos na Internet. 2014. Disponível em:< http://noticias.r7.com/internacional/suposto-bibliotecario-da-alqaeda-nega-marcacao-de-alvos-na-internet-24042014>. Acesso: 28. Ago. 2014.

TOURAINE, A. O que é democracia? Petrópolis, RJ: Vozes, 1996.

UNESCO. The Unesco public library manifesto (1994). Unisist Newsletter, Paris, v. 23, n. 1, 1995.

UNGER R. J. G.; FREIRE, I. M. Sistemas de informação e linguagens documentárias no contexto dos regimes de informação: um exercício conceitual. Revista Digital de Biblioteconomia e Ciência da Informação, Campinas, v. 4, n. 1, p. 102-115, jul./dez. 
2006. Disponível em: <http://server01.bc.unicamp.br/seer. php?id=82>. Acesso em: 08 dez. 2014.

VALENTIM, M. L. P. Atuação e perspectivas profissionais para o profissional da informação. In: (Org.). Profissionais da informação. São Paulo: Polis, 2000a.

VALENTIM, M. P. (org.). Profissionais da informação: formação, perfil e atuação profissional. São Paulo: Polis, 2000b.

WALTER, M. T. M. T. Bibliotecários no Brasil: representações da profissão. 2008. 345f. Tese (Doutorado em Ciência da Informação) - Universidade de Brasília, Brasília, 2008.

WERSIG, G. Information science: the study of postmodern knowledge usage. Information- Processing and Management, New York, v. 29, n. 2, p. 229-239, 1993.

ZAIDAN FILHO, M. Ensaios de teoria. Recife: NEEPD, 2012. 


\title{
ANEXO A: LEGISLAÇÃO QUE REGULAM A PROFISSÃO DE BIBLIOTECÁRIO
}

\author{
LEI № 4.084 DE 30 DE JUNHO DE 1962 \\ Dispõe sobre a profissão do Bibliotecário e regula seu exercício
}

O Presidente da República:

Faço saber que o Congresso Nacional decreta e eu sanciono a seguinte Lei:

O Congresso Nacional Decreta:

\section{Do Exercício da Profissão do Bibliotecário e das suas Atribuições}

Art. 1ํ - A designação profissional de Bibliotecário, a que se refere o quadro das profissões liberais, grupo 19, anexo ao Decreto-Lei $n^{\circ} 5.452$, de $1^{\circ}$ de maio de 1943 (Consolidação das Leis do Trabalho), é privativa dos Bacharéis em Biblioteconomia, de conformidade com as leis em vigor.

Art. 2ㅇ - O exercício da profissão de Bibliotecário, em qualquer de seus ramos, só será permitido:

a) aos Bacharéis em Biblioteconomia, portadores de diplomas expedidos por Escolas de Biblioteconomia de nível superior, oficiais, equiparadas, ou oficialmente reconhecidas;

b) aos Bibliotecários portadores de diplomas de instituições estrangeiras que apresentem os seus diplomas revalidados no Brasil, de acordo com a legislação vigente.

Parágrafo único - Não será permitido o exercício da profissão aos diplomados por escolas ou cursos cujos estudos hajam sido feitos através de correspondência, cursos intensivos, cursos de férias, etc.

Art. 3 - Para o provimento e o exercício de cargos técnicos de Bibliotecários, Documentalistas e Técnicos de Documentação na administração pública federal, estadual ou municipal, autárquica, paraestatal, nas empresas de economia mista ou nas concessionárias de serviços públicos é obrigatória a apresentação de diploma de Bacharel em Biblioteconomia, respeitados os direitos dos atuais ocupantes (redação dada pela Lei no 7.504, de 02/07/1986). 
Art. 4 - Os profissionais de que trata o artigo $2^{\circ}$, letras "a" e "b" desta lei, só poderão exercer a profissão após haverem registrado seus títulos ou diplomas na Diretoria de Ensino Superior do Ministério da Educação e Cultura.

Art. 50 - O certificado de registro ou a apresentação do título registrado, será exigido pelas autoridades federais, estaduais ou municipais para assinatura de contratos, termos de posse, inscrição em concursos, pagamentos de licenças ou imposto para exercício da profissão e desempenho de quaisquer funções a esta inerentes.

Art. 6 - São atribuídas aos Bacharéis em Biblioteconomia, a organização, direção e execução dos serviços técnicos de repartições públicas federais, estaduais, municipais e autarquias e empresas particulares concernentes às matérias e atividades seguintes:

a) o ensino de Biblioteconomia;

b) a fiscalização de estabelecimentos de ensino de Biblioteconomia reconhecidos, equiparados ou em via de equiparação;

c) administração e direção de bibliotecas;

d) a organização e direção dos serviços de documentação;

e) a execução dos serviços de classificação e catalogação de manuscritos e de livros raros e preciosos, de mapotecas, de publicações oficiais e seriadas, de bibliografia e referência.

Art. 7ํ - Os Bacharéis em Biblioteconomia terão preferência, quanto à parte relacionada à sua especialidade nos serviços concernentes a:

a) demonstrações práticas e teóricas da técnica biblioteconômica em estabelecimentos federais, estaduais ou municipais;

b) padronização dos serviços técnicos de biblioteconomia;

c) inspeção, sob o ponto de vista de incentivar e orientar os trabalhos de recenseamento, estatística e cadastro de bibliotecas;

d) publicidade sobre material bibliográfico e atividades da biblioteca;

e) planejamento de difusão cultural, na parte que se refere a serviços de bibliotecas;

f) organização de congressos, seminários, concursos e exposições nacionais ou estrangeiras, relativas a Biblioteconomia e Documentação ou representação oficial dos Conselhos de Biblioteconomia em tais certames.

\section{Dos Conselhos de Biblioteconomia}

Art. 8 - A fiscalização do exercício da profissão do Bibliotecário será exercida pelo Conselho Federal de Biblioteconomia e pelos Conselhos Regionais de Biblioteconomia, criados por esta Lei. 
Art. 9o - O Conselho Federal de Biblioteconomia e os Conselhos Regionais de Biblioteconomia são dotados de personalidade jurídica de direito público, autonomia administrativa e patrimonial.

Art. 10ㅇ - A sede do Conselho Federal de Biblioteconomia será no Distrito Federal.

Art. 11 - O Conselho Federal de Biblioteconomia será constituído de brasileiros natos ou naturalizados e obedecerá a seguinte composição:

a) um presidente, nomeado pelo Presidente da República e escolhido entre os nomes constantes da lista tríplice organizada pelos membros do Conselho;

b) seis (6) conselheiros federais efetivos e três (3) suplentes, escolhidos em assembléia constituída por delegados-eleitores de cada Conselho Regional de Biblioteconomia;

c) seis (6) conselheiros federais efetivos, representantes da Congregação das Escolas de Biblioteconomia do Distrito Federal e de todo o Brasil, cujos nomes serão encaminhados pelas Escolas em listas tríplices, ao Conselho de Biblioteconomia.

Parágrafo Único - $\mathrm{O}$ número de conselheiros federais poderá ser ampliado em mais de três, mediante resolução do Conselho Federal de Biblioteconomia, conforme necessidades futuras.

Art. 12 - Dentre os seis conselheiros federais efetivos de que trata a letra "b" do artigo 11 da presente Lei, quatro devem satisfazer as exigências das letras "a" e "b" e dois poderão ser escolhidos entre os que se enquadram no artigo $4^{\circ}$ desta mesma Lei.

Parágrafo único - $\mathrm{Na}$ escolha dos dois (2) conselheiros federais efetivos de que trata 0 artigo 11 da presente Lei, haverá preferência para os titulares que exerçam cargos de chefia ou direção.

Art. 13 - Os três (3) suplentes indicados na letra "b" do artigo 11 só poderão ser escolhidos entre os que se enquadram nas letras "a" e "b" do artigo $2^{\circ}$ da presente lei.

Art. 14 - O mandato do Presidente, dos conselheiros federais efetivos e dos suplentes terá a duração de 3 (três) anos.

Art. 15 - São atribuições do Conselho Federal de Biblioteconomia:

a) organizar o seu Regimento Interno;

b) aprovar os regimentos internos organizados pelos Conselhos Regionais, modificando o que se tornar necessário, com a finalidade de manter a unidade de ação;

c) tomar conhecimento de quaisquer dúvidas suscitadas pelos Conselhos Regionais de Biblioteconomia, promovendo as providências que se fizerem necessárias, tendentes a favorecer a homogeneidade de orientação dos serviços de biblioteconomia; 
d) julgar, em última instância, os recursos das deliberações dos Conselhos Regionais de Biblioteconomia;

e) publicar o relatório anual de seus trabalhos e, periodicamente, relação de todos os profissionais registrados;

f) expedir as resoluções que se tornem necessárias para a fiel interpretação e execução de presente Lei;

g) propor ao Governador Federal as modificações que se tornarem convenientes para melhorar a regulamentação do exercício da profissão de Bibliotecário;

h) deliberar sobre questões oriundas do exercício de atividades afins à especialidade do Bibliotecário;

i) convocar e realizar, periodicamente, congressos de conselheiros federais para estudar, debater e orientar assuntos referentes à profissão.

Parágrafo único - As questões referentes às atividades afins com as de outras profissões serão resolvidas através de entendimentos com as entidades reguladoras dessas profissões.

Art. 16 - O Conselho Federal de Biblioteconomia só deliberará com a presença mínima de metade mais um de seus membros.

Parágrafo único - As resoluções a que se refere a alínea "f" do artigo 15 só serão válidas quando aprovadas pela maioria dos membros do Conselho Federal de Biblioteconomia.

Art. 17 - Ao Presidente do Conselho Federal de Biblioteconomia compete, até julgamento da direção do Conselho, a suspensão de decisão que o mesmo tome e Ihe pareça inconveniente.

Parágrafo único - $\mathrm{O}$ ato de suspensão vigorará até o novo julgamento do Conselho, caso para o qual o Presidente convocará segunda reunião no prazo de 30 (trinta) dias, contados do seu ato. Se no segundo julgamento o Conselho mantiver por dois terços de seus membros a decisão suspensa, esta entrará em vigor imediatamente.

Art. 18 - O Presidente do Conselho Federal de Biblioteconomia é o responsável administrativo pelo Conselho Federal de Biblioteconomia, inclusive pela prestação de contas perante o órgão competente.

Art. 19 - O Conselho Federal de Biblioteconomia fixará a composição dos Conselhos Regionais de Biblioteconomia, procurando organizá-los à sua semelhança; promoverá a instalação de tantos órgãos quanto forem julgados necessários, fixando as suas sedes e zonas de jurisdição.

Art. 20 - As atribuições dos Conselhos Regionais de Biblioteconomia são as seguintes:

a) registrar os profissionais de acordo com a presente Lei e expedir carteira profissional; 
b) examinar reclamações e representações escritas acerca dos serviços de registro e das infrações desta Lei e decidir, com recurso, para o Conselho Federal de Biblioteconomia;

c) fiscalizar o exercício da profissão, impedindo e punindo as infrações à lei, bem como enviando às autoridades competentes relatórios documentados sobre fatos que apurarem e cuja solução não seja de sua alçada;

d) publicar relatórios anuais dos seus trabalhos e, periodicamente, relação dos profissionais registrados;

e) organizar o regimento interno, submetendo-o à aprovação do Conselho Federal de Biblioteconomia;

f) apresentar sugestões ao Conselho Federal de Biblioteconomia;

g) admitir a colaboração das Associações de Bibliotecários, nos casos das matérias das letras anteriores;

h) eleger um delegado-eleitor para a assembléia referida na letra "b" do artigo11.

Art. 21 - A escolha dos conselheiros regionais efetuar-se-á em assembléias realizadas nos Conselhos Regionais, separadamente por delegados das Escolas de Biblioteconomia e por delegados eleitos pelas Associações de Bibliotecários, devidamente registrados no Conselho Regional respectivo.

Parágrafo único - Os diretores de Escolas de Biblioteconomia e os Presidentes das Associações de Bibliotecários são membros natos dos Conselhos Regionais de Biblioteconomia.

Art. 22 - Todas as atribuições referentes ao registro, à fiscalização e à imposição de penalidades, quanto ao exercício da profissão de Bibliotecário, passam a ser da competência dos Conselhos Regionais de Biblioteconomia.

Art. 23 - Os Conselhos Regionais de Biblioteconomia poderão, por procuradores seus, promover perante o Juiz da Fazenda Pública e mediante processo de executivo fiscal, a cobrança das penalidades ou anuidades previstas para a execução da presente Lei.

Art. 24 - A responsabilidade administrativa de cada Conselho Regional cabe ao respectivo Presidente, inclusive a prestação de contas perante o órgão federal competente.

Art. 25 - O Conselheiro federal ou regional que, durante um ano, faltar, sem licença prévia dos respectivos Conselhos, a seis (6) sessões consecutivas ou não, embora com justificação, perderá, automaticamente, o mandato que passará a ser exercido, em caráter efetivo, pelo respectivo suplente.

Anuidades e Taxas

Art. 26 - O Bacharel em Biblioteconomia, para o exercício de sua profissão, é obrigado ao registro no Conselho Regional de Biblioteconomia a cuja jurisdição 
estiver sujeito, ficando obrigado ao pagamento de uma anuidade ao respectivo Conselho Regional de Biblioteconomia, até o dia 31 de março de cada ano, acrescida de $20 \%$ (vinte por cento) de mora, quando fora deste prazo.

Art. 27 - Os Conselhos Regionais de Biblioteconomia cobrarão taxas pela expedição ou substituição de carteiras profissionais e pela certidão referente à anotação de função técnica.

Art. 28 - O poder Executivo promoverá, em decreto, a fixação das anuidades e taxas a que se referem os artigos 26, 29 e 30 e sua alteração só poderá ter lugar com intervalos não inferiores a três anos, mediante proposta do Conselho Federal de Biblioteconomia.

Art. 29 - Constitui renda do Conselho Federal de Biblioteconomia o seguinte:

a) 1/4 da taxa de expedição da carteira profissional;

b) $1 / 4$ da anuidade de renovação do registro;

c) 1/4 das multas aplicadas de acordo com a presente Lei;

d) doações;

e) subvenções dos governos;

f) $1 / 4$ da renda de certidões.

Art. 30 - A renda de cada Conselho Regional de Biblioteconomia será constituída do seguinte:

a) 3/4 da renda proveniente da expedição de carteiras profissionais;

b) $3 / 4$ da anuidade da renovação de registro;

c) $3 / 4$ das multas aplicadas de acordo com a presente Lei;

d) doações;

e) subvenções dos governos;

f) $3 / 4$ da renda das certidões.

\section{Disposições Gerais}

Art. 31 - Os presidentes dos Conselhos Federal e Regionais de Biblioteconomia prestarão anualmente suas contas perante o Tribunal de Contas da União.

$\S 1^{\circ}$ - A prestação de contas do Presidente do Conselho Federal de Biblioteconomia será feita diretamente ao referido Tribunal, após a aprovação do Conselho.

$\S 2^{0}$ - A prestação de contas dos presidentes dos Conselhos Regionais de Biblioteconomia será feita ao referido Tribunal, por intermédio do Conselho Federal de Biblioteconomia. 
$\S 3^{\circ}$ - Cabe aos presidentes de cada Conselho a responsabilidade pela prestação de contas.

Art. 32 - Os casos omissos verificados nesta lei serão resolvidos pelo Conselho Federal de Biblioteconomia.

\section{Disposições Transitórias}

Art. 33 - A Assembléia que se realizar para a escolha dos seis (6) primeiros conselheiros efetivos e dos três (3) primeiros conselheiros suplentes do Conselho Federal de Biblioteconomia, previsto na conformidade da letra "b" do artigo 11 desta Lei, será presidida pelo consultor-técnico do Ministério do Trabalho e Previdência Social e se constituirá dos delegados-eleitores, dos representantes das Associações de classe, das Escolas de Biblioteconomia, eleitos em assembléias das respectivas instituições por voto secreto e segundo as formalidades estabelecidas para a escolha de suas diretorias ou órgãos dirigentes.

$\S 1$ 1 - Cada Associação de Bibliotecários indicará um único delegado-eleitor que deverá ser, obrigatoriamente, sócio efetivo e no pleno gozo de seus direitos sociais, e profissionais de Biblioteconomia possuidor de diploma de Bibliotecário.

$\S 2^{\circ}$ - Cada Escola ou Cursos de Biblioteconomia se fará representar por um único delegado-eleitor, professor em exercício, eleito pela respectiva congregação.

$\S 3^{\circ}$ - Só poderá ser eleito na Assembléia a que se refere este artigo, para exercer o mandato de Conselheiro Federal de Biblioteconomia, o profissional que preencha as condições estabelecidas no artigo 13 da presente Lei.

$\S 4^{\circ}$ - As Associações de Bibliotecários, para obterem seus direitos de representação na Assembléia a que se refere este artigo, deverão preceder dentro do prazo de noventa (90) dias, a partir da data desta Lei, ao seu registro prévio perante o consultor-técnico do Ministério de Trabalho e Previdência Social, mediante a apresentação de seus estatutos e mais documentos julgados necessários.

$\S 5$ - - Os seis conselheiros referidos na letra "c" do artigo 11 da presente Lei serão credenciados pelas respectivas Escolas, junto ao consultor-técnico do Ministério do Trabalho e Previdência Social.

Art. 34 - O Conselho Federal de Biblioteconomia procederá, na sua primeira seção, ao sorteio dos conselheiros federais de que trata a letra $c$ do artigo 11 desta Lei e que deverão exercer o mandato por três (3) anos.

Art. 35 - Em Assembléia dos conselheiros federais efetivos eleitos na forma do artigo 11, presidida pelo consultor-técnico do Ministério do Trabalho e Previdência Social, serão votados os tríplices a que se refere "a" letra a do artigo 11 da presente Lei, para escolha do primeiro presidente do Conselho Federal de Biblioteconomia. 
Art. 36 - Durante o período da organização do Conselho Federal de Biblioteconomia, o Ministério do Trabalho e Previdência Social designará um local para sua sede e, à requisição do Presidente deste Conselho, fornecerá o material e pessoal necessários ao serviço.

Art. 37 - Esta lei estará em vigor na data de sua publicação, revogadas as disposições em contrário.

Brasília, 30 de junho de 1962; 141ํ da Independência e 74 da República.

Publicada no Diário Oficial da União em 02/07/1962 - Seção I - p. 1-2.

\section{DECRETO-LEI № 56.725, DE 16 DE AGOSTO DE 1965}

\section{Regulamenta a lei № 4.084, de 30 de junho de 1962, que dispõe sobre o exercício da profissão de Bibliotecário.}

O Presidente da República, usando da atribuição que lhe confere o Art.87, item I, da constituição, decreta:

\section{TITULO I - Da profissão de Bibliotecário}

\section{CAPÍTULO I - Do Bibliotecário}

Art. 1 - A Biblioteconomia, em qualquer de seus ramos, constitui o objeto da profissão liberal de Bibliotecário, de natureza técnica de nível superior.

Art. 20 - A designação profissional de Bibliotecário passa a ser incluída no Quadro das profissões Liberais, grupo 19, anexo ao Decreto-lei № 5.452 , de $1^{\circ}$ de maio de 1943 (Consolidação das leis do Trabalho), sendo privativa dos Bacharéis em Biblioteconomia, de conformidade com as leis em vigor.

Art. 3 - A profissão de Bibliotecário será exercida, exclusivamente, pelos:

I - Bacharéis em Biblioteconomia, possuidores de diplomas expedidos por Escolas de Biblioteconomia de nível superior, oficiais, equiparadas ou oficialmente reconhecidas;

II - Bibliotecários diplomados por escolas estrangeiras, reconhecidas pelas leis do país de origem, cujos diplomas tenham sido revalidados no Brasil, de conformidade com a legislação em vigor.

Parágrafo único - Não poderão exercer a profissão de Bibliotecário os diplomados por escolas ou cursos, cujos estudos hajam sido feitos através de correspondência, cursos intensivos, cursos de férias, seminário, etc.

Art. 4 - Os profissionais de que trata o artigo anterior somente poderão exercer a profissão, após satisfazer os seguintes requisitos: 
I - registro dos diplomas ou títulos na Diretoria do Ensino Superior, do Ministério da Educação e Cultura;

II - registro no Conselho Regional de Biblioteconomia a cuja jurisdição estiverem sujeitos;

III - pagamento da anuidade ao Conselho Regional de Biblioteconomia, na forma estabelecida neste Regulamento.

\section{CAPITULO II - Da Atividade Profissional}

Art. 5 - A profissão de Bibliotecário, observadas as condições previstas neste Regulamento, se exerce na órbita pública e na órbita privada por meio de estudos, pesquisas, análises, relatórios, pareceres, sinopses, resumos, bibliografias sobre assunto compreendidos no seu campo profissional, inclusive por meio de planejamento, implantação, orientação, supervisão, direção, execução ou assistência nos trabalhos relativos às atividades biblioteconômicas, bibliográficas e documentológicas, em empreendimentos públicos, privados ou mistos, ou por outros meios que objetivarem, tecnicamente, o desenvolvimento das bibliotecas e centros de documentação.

Art. 6 - Os documentos referentes ao campo de ação profissional de que trata o artigo anterior só terão validade quando assinados por Bibliotecário devidamente registrado, na forma deste Regulamento.

Art. 7ํㅡ - É obrigatória a citação do número de registro de Bibliotecário no competente Conselho Regional de Biblioteconomia, após a assinatura de qualquer trabalho relacionado com as atividades a que se refere 0 artigo 5․

Art. 8 - São atribuições do Bibliotecário a organização, direção e execução dos serviços técnicos de repartições públicas federais, estaduais, municipais e autárquicas, bem como de empresas particulares, concernentes às matérias e atividades seguintes:

I - o ensino das disciplinas específicas de Biblioteconomia;

II - a fiscalização de estabelecimentos de ensino de Biblioteconomia

reconhecidos, equiparados ou em via de equiparação;

III - administração e direção de bibliotecas;

IV - organização e direção dos serviços de documentação;

V - execução dos serviços de classificação e catalogação de manuscrito e de livros raros ou preciosos, de mapotecas, de publicação oficiais e seriadas, de bibliografia e referência.

Art. 9 - O Bibliotecário terá preferência, quanto à parte relacionada com sua especialidade, no desempenho das atividades concernentes a:

I - demonstrações práticas e teóricas da técnica biblioteconômica em estabelecimento federais, estaduais ou municipais;

II - padronização dos serviços técnicos de Biblioteconomia; 
III - inspeção, sob o ponto de vista de incentivar e orientar os trabalhos de recenseamento, estatística e cadastro das bibliotecas;

IV - publicidade sobre material bibliográfico e atividades da biblioteca;

V - planejamento de difusão cultural, na parte que se refere a serviço de biblioteca;

VI - organização de congressos, seminários, concursos e exposições nacionais e estrangeiras, relativas à Biblioteconomia e à Documentação ou representação oficial em tais certames.

Art. 10 - O provimento e exercício de cargo técnico ou de magistério de Biblioteconomia, em qualquer de seus ramos, na forma especificada no artigo $5^{\circ}$, na administração pública federal, estadual ou municipal, autárquica, paraestatal, nas empresas sob intervenção governamental, nas concessionárias de serviços públicos, são privativos dos profissionais de que trata o artigo 3‥

$\S 1^{\circ}$ - O disposto neste artigo não prejudica direitos dos atuais ocupantes efetivos dos cargos a que alude este artigo, os quais ficam obrigados às exigências constantes dos itens II e III do artigo 4ํ․

$\S 2^{\circ}$ - A apresentação do comprovante de habilitação profissional não dispensa a prestação do respectivo concurso, quando este for exigido para o provimento dos cargos a que se refere este artigo.

Art. 11 - As autoridades federais, estaduais ou municipais, bem como as empresas particulares, deverão exigir os documentos mencionados no artigo 4ำ para assinatura de contratos, termos de posse, inscrição em concursos, pagamentos de licença ou imposto para o exercício da profissão de Bibliotecário e desemprego de quaisquer funções a esta inerente.

\section{TíTULO II - Dos Conselhos de Biblioteconomia}

\section{CAPÍTULO III - Parte Geral}

Art. 12 - A fiscalização do exercício da profissão de Bibliotecário será exercida pelos Conselhos Regionais de Biblioteconomia (CRB), sob a supervisão do Conselho Federal de Biblioteconomia (CFB).

Art. 13 - O CFB e os CRB são dotados de personalidade jurídica de direito pública e de autonomia administrativa e patrimonial.

Art. 14 - O Poder Executivo fixará, mediante decreto, as anuidades e taxas previstas neste Regulamento, as quais somente poderão ser alteradas com intervalo não inferior a três anos.

Parágrafo único - As medidas de que trata este artigo serão propostas pelo CFB.

\section{CAPITULO IV - Do Conselho Federal de Biblioteconomia}

Art. 15 - O CFB tem por finalidade orientar, supervisionar e disciplinar o exercício da profissão de Bibliotecário, em todo o território nacional, na forma deste 
Regulamento, bem como contribuir para o desenvolvimento biblioteconômico no País.

Art. 16 - A sede do CFB será no Distrito Federal.

Art. 17 - O CFB será constituído de bibliotecários, brasileiros natos ou naturalizados, e obedecerá à seguinte composição:

I - um presidente, nomeado pelo Presidente da República e escolhido dentre os Conselheiros federais efetivos, indicados em lista tríplice organizada pelos membros do CFB;

II - seis (6) Conselheiros federais efetivos os três (3) suplentes, escolhidos em assembléia constituída por delegados-eleitores dos CRB;

III - seis (6) Conselheiros federais efetivos representantes da Congregação das Escolas de Biblioteconomia do Distrito Federal e de todo o Brasil, cujos nomes serão encaminhados pelas Escolas, em listas tríplices, ao CFB.

$\S 1^{\circ}$ - O número de Conselheiros federais poderá ser ampliado de mais três, mediante resolução do CFB, conforme necessidades futuras.

$\S 2^{\circ}$ - O presidente e demais Conselheiros do CFB tomarão posse perante 0 Ministério do Trabalho e Previdência Social.

Art. 18 - Dentre os seis (6) Conselheiros federais efetivos, de que trata o item III do artigo anterior, quatro (4) devem satisfazer as exigências dos itens I e II do artigo 3응 e dois (2) restantes poderão ser escolhidos entre os que preencham o requerido do artigo $4^{\circ}$, item I.

Parágrafo único - Na escolha dos dois Conselheiros federais efetivos de que trata a parte final deste artigo, terão preferência os que forem titulares de cargos ou funções de chefia ou direção.

Art. 19 - Os três (3) suplentes indicados no item II do artigo 17 só poderão ser escolhidos entre os que se enquadrem nos itens I e II do artigo $3^{\circ}$.

Art. 20 - O mandato dos membros efetivos e suplentes do CFB será de três anos, podendo ser renovado.

Parágrafo único - O mandato do presidente se extinguirá juntamente com o dos demais conselheiros.

Art. 21 - As eleições para escolha dos membros do CFB, efetivos e suplentes, de que trata o item II do artigo 17, serão realizadas na sede do CFB, trienalmente, no último semestre dos mandatos vigentes, pelos delegados-eleitores representantes de cada CRB.

Parágrafo único - Eleitos os Conselheiros a que se refere este artigo, será realizado, perante eles, o sorteio dos Conselheiros de que trata o item III do artigo 17 , dentre os nomes constantes das listas tríplices mencionadas nesse artigo.

Art. 22 - A Assembléia de Delegados-Eleitores, para os fins previstos no artigo anterior, será realizada, em primeira convocação com presença mínima de 2/3 (dois terços) e, em segunda, com qualquer número de representantes, sendo instalada pelo Presidente do CFB e presidida por um de seus membros.

$\S 1^{\circ}$ - O CFB baixará e publicará normas para as eleições. 
$\S 2^{\circ}$ - As entidades que não credenciarem seus representantes para o fim previsto no artigo 17, dentro do prazo fixado pelo CFB, perderão o direito de se fazerem representar.

$\S$ 3ํ. - Cada CRB terá um delegado-eleitor.

Art. 23 - Os membros do CFB serão substituídos nos casos de faltas,

impedimentos ou vacâncias, pelos suplentes na ordem de votos por estes obtidos e, em caso de número igual de votos, por aquele que for escolhido em escrutínio secreto do Plenário.

Art. 24 - O membro do CFB que faltar, sem prévia licença, embora com posterior justificação, a seis (6) sessões ordinárias, consecutivas ou não, no período de um ano, perderá automaticamente o mandato, que passará a ser exercido na forma de artigo anterior.

Parágrafo único - O membro do C.F.B que tiver necessidade de ausentar-se da sede, por prazo superior a trinta (30) dias, poderá ser licenciado a pedido, por deliberação do Plenário.

Art. 25 - O CFB terá como órgão deliberativo o Plenário, cabendo à respectiva Presidência as atividades executivas de administração.

Parágrafo único - Haverá no CFB uma secretaria executiva, com organização e atribuições definidas no Regimento Interno.

Art. 26 - O CFB poderá organizar Comissões ou Grupos de Trabalho, para execução de determinadas tarefas.

Art. 27 - Compete ao CFB:

I - elaborar e expedir o seu Regimento Interno;

II - promover estudos e campanhas em prol do desenvolvimento biblioteconômico do País;

III - elaborar anualmente o programa das atividades definidas neste Regulamento;

IV - aprovar a proposta orçamentária;

V - organizar os CRB, fixando-Ihe a composição, a jurisdição e a forma de eleição de seus membros, adaptadas às normas constantes deste Regulamento;

$\mathrm{VI}$ - examinar e aprovar os Regimentos Internos dos CRB, podendo modificá-los no que se torna necessário, a fim de manter-se a respectiva unidade de ação; VII julgar, em última instância, os recursos das deliberações dos CRB;

VIII - tomar conhecimento de quaisquer dúvidas suscitadas pelos CRB e dirimi-las;

IX - adotar as providências que julgar necessárias para manter, uniformemente, em todos o País, a devida orientação dos CRB;

$X$ - publicar o relatório anual de seus trabalhos e, periodicamente, a relação de todos os profissionais registrados;

XI - expedir resoluções visando a fiel execução do presente Regulamento;

XII - propor ao Governo Federal as modificações que se tornarem convenientes, para melhorar a legislação referente ao exercício da profissão de Bibliotecário; 
XIII - deliberar sobre questões oriundas do exercício de atividades afins à especialidade do bibliotecário;

XIV - convocar e realizar, periodicamente, congressos de Conselheiros federais, para estudar, debater e orientar assuntos referentes à profissão;

XV - orientar e supervisionar o exercício da profissão de Bibliotecário, em qualquer de seus ramos; $\mathrm{e}$

$\mathrm{XVI}$ - propor as anuidades e taxas a serem fixadas pelo Poder Executivo, nos termos do artigo 14.

$\S 1^{\circ}$ - As questões referentes às atividades de Bibliotecário que guardem afinidades com as outras profissões serão resolvidas através de entendimentos com as entidades reguladoras dessas profissões.

Art. 28 - Ao Presidente do CFB compete, até julgamento do Plenário do Conselho, suspender a decisão que o mesmo tome e lhe pareça inconveniente.

Parágrafo único - $O$ ato de suspensão a que se refere este artigo vigorará até novo julgamento do CFB, mediante convocação do presidente, dentro do prazo de trinta (30) dias, contados a partir de seu ato. Caso a decisão do CFB seja mantida por 2/3 (dois terços) de seus membros, a decisão suspensa entrará em vigor imediatamente.

Art. 29 - O CFB deliberará com a presença mínima de metade mais um de seus membros.

Parágrafo único - As resoluções a que se refere o item XI do artigo 27 só serão válidas quando aprovadas pela maioria absoluta dos membros do CFB.

Art. 30 - Constitui renda do CFB:

I - 1/4 (um quarto) da taxa de expedição da carteira profissional;

II - 1/4 (um quarto) da anuidade de renovação do registro;

III - 1/4 (um quarto) das multas aplicadas na forma deste Regulamento;

IV - doações;

$V$ - subvenções dos Governos;

$\mathrm{VI}-1 / 4$ (um quarto) da renda das certidões.

\section{CAPÍTULO V - Dos Conselhos Regionais de Biblioteconomia}

Art. 31 - A composição e organização dos CRB serão estabelecidas pelo CFB, à sua semelhança.

Parágrafo único - O CFB promoverá a instalação de tantos CRB que forem julgados necessários, fixando as suas sedes e zonas de jurisdição.

Art. 32 - A escolha dos Conselheiros Regionais efetuar-se-á em assembléias realizadas nas sedes dos CRB, separadamente por delegados das Escolas de Biblioteconomia e por Delegados Eleitos pelas Associações de Bibliotecários, devidamente registrados no CRB respectivos.

Parágrafo único - Os diretores de Escolas de Biblioteconomia e os Presidentes das Associações de Biblioteconomia são membros natos do CRB. 
Art. 33 - Os CRB poderão, por procuradores seus, promover a cobrança judicial das anuidades e multas previstas neste Regulamento.

Art. 34 - O Conselheiro Regional que, no período de um ano, faltar a seis (6) sessões, consecutivas ou não, sem licença prévia do respectivo CRB, embora com posterior justificação, perderá, automaticamente, o mandato que passará a ser exercido, até o seu término, por um suplente.

Art. 35 - Compete ao CRB:

I - registrar os profissionais de que trata o presente Regulamento e expedir a carteira profissional, após a cobrança da respectiva taxa;

II - fiscalizar o exercício da profissão de Bibliotecário, punindo as infrações a este Regulamento, bem como enviando às autoridades competentes relatórios documentados sobre fatos que apurarem e cuja solução não seja sua alçada;

III - realizar o programa anual de atividades elaborado pelo CFB, a que se refere o item III do artigo 27;

IV - elaborar o seu Regimento Interno, submetendo-o ao exame e aprovação do CFB;

$\mathrm{V}$ - arrecadar as anuidades, taxas, multas e demais rendimentos, bem como promover a distribuição das cotas, na forma prevista neste Regulamento;

VI - examinar e decidir reclamações e representações escritas acerca do serviço de registro e das infrações deste Regulamento, cabendo de suas decisões recurso ao CFB;

VII - publicar relatórios anuais de seus trabalhos, dos quais deverá constar a relação dos profissionais registrados;

VIII - apresentar sugestões ao CFB;

IX - admitir a colaboração das Associações de Bibliotecários, sobre as matérias de sua competência;

$X$ - eleger um delegado-eleitor para a assembléia referida no item II do artigo 17;

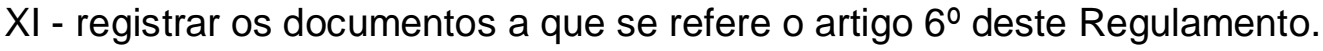

Art. 36 - Constituem rendas do CRB:

I - 3/4 (três quartos) da renda proveniente da expedição de carteiras profissionais;

II - 3/4 (três quartos) da anuidade de renovação de registros;

III - 3/4 (três quartos) das multas aplicadas;

IV - doações;

V - subvenções governamentais;

VI - 3/4 (três quartos) da renda das certidões. 


\section{CAPITULO VI - Das prestações de contas}

Art. 37 - A responsabilidade administrativa do CFB e de cada CRB caberá aos respectivos Presidentes, inclusive a prestação de contas perante o órgão federal competente.

Art. 38 - Os Presidentes do CFB e CRB prestarão, anualmente, suas contas perante o Tribunal de Contas da União.

$\S 1^{\circ}$ - A prestação de contas do Presidente do CFB será feita diretamente ao referido Tribunal, após a aprovação do Plenário.

$\S 2^{\circ}$ - A prestação de contas dos Presidentes do CRB, após a sua aprovação pelo Plenário, será feita ao referido Tribunal, por intermédio do CFB.

\section{CAPÍTULO VII - Do Registro e da Carteira de Identidade Profissional}

Art. 39 - Os profissionais a que se refere este Regulamento só poderão exercer legalmente a profissão após prévio registro de seus títulos ou diplomas na Diretoria do Ensino Superior do Ministério da Educação e Cultura, e quando portadores da Carteira de Identidade Profissional, expedidas pelo respectivo CRB, sob cuja jurisdição se achar o local de sua atividade.

Art. 40 - Ao profissional devidamente registrado será fornecida, pelo CRB respectivo, uma carteira de identidade profissional, da qual constarão:

I - nome por extenso do profissional;

II - filiação;

III - nacionalidade;

IV - data do nascimento;

$\mathrm{V}$ - estado civil;

VI - denominação da Escola em que se diplomou ou declaração de habitação, na forma deste Regulamento;

VII - número de registro do diploma na Diretoria do Ensino Superior;

VIII - número de registro no CRB respectivo;

IX - fotografia de frente;

$X$ - impressão dactiloscópica;

$X$ - assinatura do Presidente do CRB respectivo e do profissional.

Parágrafo único - A expedição da carteira de identidade profissional é sujeita ao pagamento da taxa fixada em decreto.

Art. 41 - A carteira profissional servirá de prova para o exercício da profissão de Bibliotecário, de carteira de identidade e terá fé pública.

Art. 42 - O profissional referido neste Regulamento ficará obrigado a pagar uma anuidade ao respectivo CRB. 
Parágrafo único - A anuidade de que trata este artigo deverá ser paga na sede do CRB a que estiver sujeito o profissional, até 31 de março de cada ano, salvo a primeira, que será paga no ato da inscrição ou do registro.

\section{CAPÍTULO VIII - Das Penalidades}

Art. 43 - A falta do competente registro no CRB torna ilegal o exercício da profissão de Bibliotecário e punível o infrator.

Art. 44 - Os CRB aplicarão as seguintes penalidades aos infratores dos dispositivos do presente Regulamento:

I - multa de valor variável entre 1/10 (um décimo) do maior salário mínimo no país e o total desse salário;

II - suspensão, de um a dois anos, do exercício da profissão de Bibliotecário que, no âmbito de sua atuação, for responsável, na parte técnica, por falsidade de documentos ou por pareceres dolosos que assinar;

III - suspensão, de seis meses a um ano, ao profissional que demonstrar, comprovadamente, incapacidade técnica no exercício da profissão, facultando-lhe ampla defesa;

IV - suspensão, até de um ano, do exercício da profissão de Bibliotecário, que agir sem decoro ou ferir a ética profissional.

Parágrafo único - No caso de reincidência da mesma infração, verificada no prazo de dois anos, a penalidade aplicável será elevada ao dobro.

Art. 45 - O CFB estabelecerá normas disciplinadoras dos processos de infração, prazo e interposições de recursos, a serem observados pelos CRB.

\section{TíTULO III - CAPÍTULO ÚNICO - Das Disposições Transitórias}

Art. 46 - A assembléia para a escolha dos seis (6) primeiros Conselheiros efetivos e dos três (3) primeiros Conselheiros suplentes do CFB, prevista no item II do artigo 17, será presidida pelo Consultor-Técnico do Ministério do Trabalho e Previdência Social ou, na sua falta, por funcionário designado pelo Titular daquela Secretaria de Estado e realizar-se-á de acordo com as instruções que forem expedidas pelo Ministério do Trabalho e Previdência Social, no prazo de sessenta (60) dias, contados da publicação deste Regulamento.

$\S 1^{\circ}$ - A assembléia de que trata este artigo será constituída de delegados eleitores, representantes das Associações de classe, das Escolas Superiores de Biblioteconomia, eleitos, em assembléias das respectivas instituições, por voto secreto e segundo as formalidades estabelecidas para a escolha de suas diretorias ou órgãos dirigentes.

$\S 2^{\circ}$ - Cada Associação de Bibliotecário indicará um delegado-eleitor, que deverá ser, obrigatoriamente, sócio efetivo e no pleno gozo de seus direitos sociais, assim como possuidor de diploma de Bibliotecário. 
$\S 3^{\circ}$ - Cada Escola ou Cursos Superior de Biblioteconomia se fará representar por um delegado-eleitor, profissional em exercício, eleito pela respectiva congregação.

$\S 4^{\circ}$ - Só poderá ser eleito, na assembléia a que se refere este artigo, para exercer o mandato de Conselheiro federal do CFB, o profissional que preencha a condição estabelecida no item I ou II do artigo 3으 do presente Regulamento.

$\S 5^{\circ}$ - As Associações de Bibliotecários, para obterem o direito de representação na assembléia a que se refere este artigo, deverão, dentro do prazo de noventa (90) dias, contados da publicação do presente Regulamento, providenciar o seu registro prévio perante a autoridade do Ministério do Trabalho e Previdência Social, mencionada neste artigo, mediante a apresentação de seus Estatutos e demais documentos julgados necessários.

Art. 47 - Os seis (6) Conselheiros federais do CFB, a que se refere o item III do artigo 17, serão credenciados pelas Escolas Superiores de Biblioteconomia respectivas, junto à autoridade do Ministério do Trabalho e Previdência Social, referida no artigo anterior.

Parágrafo único - O CFB realizará, em sua primeira sessão, o sorteio dos Conselheiros federais de que trata 0 item III do artigo 17 e que deverão exercer 0 mandato por três (3) anos.

Art. 48 - Os Conselheiros federais efetivos do CFB, eleitos na forma dos artigos $46 \mathrm{e}$ 47, em sessão presidida pela autoridade do Ministério do Trabalho e Previdência Social, mencionada no artigo 46, escolherão, dentre eles, os três nomes que constituirão a lista tríplice a ser submetida ao Presidente da República, para nomeação do primeiro Presidente do CFB.

Art. 49 - Até que se efetive a mudança de todo o Ministério do Trabalho e Previdência Social para o Distrito Federal, a sede provisória do C.F.B será determinada mediante portaria do Titular daquela pasta.

Parágrafo único - Caberá ao Ministério do Trabalho e Previdência Social, mediante requisição do Presidente do CFB, ordenar o fornecimento de pessoal e material necessários à implantação dos respectivos serviços.

Art. 50 - Dentro do prazo de cento e vinte (120) dias, após a sua instalação, o CFB expedirá os atos de composição e organização dos CRB a que se refere o artigo 31 deste Regulamento, e tomará as providências indispensáveis à eleição dos Conselheiros Regionais.

Art. 51 - Na execução deste Regulamento, os casos omissos serão resolvidos pelo CFB.

Art. 52 - O Presente Regulamento entrará em vigor na data de sua publicação, revogados as disposições em contrário.

Brasília, 16 de agosto de 1965; 144ํ da Independência e 77º da República.

Publicada no Diário Oficial da União em 19/08/1965. 


\section{LEI № 9.674, DE 26 DE JUNHO DE 1998}

\section{Dispõe sobre o exercício da profissão de Bibliotecário e determina outras providências.}

O PRESIDENTE DA REPÚBLICA:

Faço saber que o Congresso Nacional decreta e eu sanciono a seguinte Lei:

\section{CAPÍTULO I - Da profissão de Bibliotecário}

Art. 1ํ - O exercício da profissão de Bibliotecário, em todo o território nacional, somente é permitido quando atendidas as qualificações estabelecidas nesta Lei.

Parágrafo único. A designação "Bibliotecário", incluída no Quadro das Profissões Liberais, Grupo 19, da Consolidação das Leis do Trabalho, é privativa dos Bacharéis em Biblioteconomia.

Art. 2ㅇ - (VETADO)

Art. 3 - O exercício da profissão de Bibliotecário é privativo:

I - dos portadores de diploma de Bacharel em Biblioteconomia, expedido por instituições de ensino superior oficialmente reconhecidas, registradas nos órgãos competentes, de acordo com a legislação em vigor;

II - dos portadores de diploma de graduação em Biblioteconomia, conferido por instituições estrangeiras de ensino superior, reconhecidas pelas leis do país de origem, e revalidados no Brasil, de acordo com a legislação vigente;

III - dos amparados pela Lei oㅜ 7.504, de 2 de julho de 1986.

\section{CAPÍTULO II - Das Atividades Profissionais}

Art. 4 - O exercício da profissão de Bibliotecário, no âmbito das pessoas jurídicas de direito público e privado, é privativo dos Bacharéis em Biblioteconomia.

Art. 5o - (VETADO).

\section{CAPÍTULO III - Dos Conselhos de Biblioteconomia}

Art. 60 - (VETADO)

Art. 70 - (VETADO)

Art. 8 - (VETADO)

Art. 9o - (VETADO)

Art. 10 - (VETADO) 
Art. 11 - (VETADO)

Art. 12 - (VETADO)

Art. 13 - (VETADO)

Art. 14 - (VETADO)

Art. 15 - (VETADO)

Art. 16 - (VETADO)

Art. 17 - (VETADO)

Art. 18 - (VETADO)

Art. 19 - (VETADO)

Art. 20 - (VETADO)

Art. 21 - (VETADO)

Art. 22 - (VETADO)

Art. 23 - (VETADO

CAPÍTULO IV - Da Finalidade e Competência do Conselho Federal de Biblioteconomia

Art. 24 - (VETADO)

Art. 25 - (VETADO)

CAPÍTULO V - Da Finalidade e Competência dos Conselhos Regionais de Biblioteconomia

Art. 26 - (VETADO)

Art. 27 - (VETADO)

Art. 28 - (VETADO)

\section{CAPÍTULO VI - Do Registro de Bibliotecário}

Art. 29 - O exercício da função de Bibliotecário é privativo dos bibliotecários inscritos nos quadros do Conselho Regional da respectiva jurisdição, nos termos desta Lei.

$\S 1$ 1 - É obrigatória a citação do número de registros no Conselho Regional, em todos os documentos de responsabilidade profissional.

$\S 2^{\circ}-($ VETADO)

Art. 30 - Ao profissional devidamente registrado no Conselho Regional serão fornecidas a carteira de identidade profissional e a cédula de identidade de Bibliotecário, que terão fé pública, nos termos da Lei. 


\section{CAPITULO VII - Do Registro das Pessoas Jurídicas}

Art. 31 - (VETADO)

Art. 32 - (VETADO)

\section{CAPÍTULO VIII - Do Cadastro das Pessoas Jurídicas}

Art. 33 - (VETADO)

$\S 1^{\circ}-(\mathrm{VETADO})$

$\S 2^{\circ}-($ VETADO)

$\S 3^{\circ}$ - As Bibliotecas Públicas localizadas em municípios com até dez mil habitantes e cujo acervo não ultrapasse a duzentos exemplares catalogados poderão funcionar sob a supervisão de um Técnico em Biblioteconomia, devidamente registrado perante o Conselho e, neste caso, deverão comunicar ao respectivo Conselho Regional de Biblioteconomia a criação, o funcionamento e a responsabilidade técnica da Biblioteca, para fins de anotação e controle, sendo isentas de qualquer taxa ou contribuição.

Art. 34 - (VETADO)

\section{CAPITULO IX - Das Anuidades, Taxas, Emolumentos, Multas e Renda}

Art. 35 - (VETADO)

Art. 36 - (VETADO)

Art. 37 - (VETADO)

\section{CAPITULO X - Das Infrações, Penalidades e Recursos}

Art. 38 - A falta do competente registro, bem como do pagamento da anuidade, caracterizará o exercício ilegal da profissão de Bibliotecário.

Art. 39 - Constituem infrações disciplinares:

I - exercer a profissão quando impedido de fazê-lo ou facilitar, por qualquer modo, o seu exercício a não registrados;

II - praticar, no exercício profissional, ato que a lei defina como crime ou contravenção penal;

III - não cumprir, no prazo estipulado, determinação emanada do Conselho Regional em matéria de competência deste, após regularmente notificado; 
IV - deixar de pagar ao Conselho Regional, nos prazos previstos, as contribuições a que está obrigado;

V - faltar a qualquer dever profissional previsto nesta Lei;

VI - transgredir preceitos do Código de Ética Profissional.

Parágrafo único. As infrações serão apuradas levando-se em conta a natureza do ato e as circunstâncias de cada caso.

Art. 40 - As penas disciplinares, consideradas a gravidade da infração cometida e a reincidência das mesmas, consistem em:

I - multa de uma a cinqüenta vezes o valor atualizado da anuidade;

II - advertência reservada;

III - censura pública;

IV - suspensão do exercício profissional de até três anos;

V - cassação do exercício profissional com a apreensão da carteira profissional.

$\S 1^{0}$ - A pena de multa poderá ser combinada com qualquer das penalidades enumeradas neste artigo, podendo ser aplicada em dobro em caso de reincidência da mesma infração.

$\S 2^{\circ}$ - A falta de pagamento da multa prevista neste capítulo no prazo estipulado determinará a suspensão do exercício profissional, sem prejuízo da cobrança por via executiva.

$\S 3^{0}$ - A suspensão por falta de pagamento de anuidades, taxas e multas somente cessará com o recolhimento da dívida, podendo estender-se a até três anos, decorridos os quais o profissional terá, automaticamente, cancelado seu registro, se não resgatar o débito, sem prejuízo da cobrança executiva.

$\S 4^{\circ}$ - A pena de cassação do exercício profissional acarretará ao infrator a perda do direito de exercer a profissão, em todo o território nacional, com apreensão da carteira de identidade profissional.

$\S 5^{\circ}$ - Ao infrator suspenso por débitos será admitida a reabilitação profissional mediante novo registro, satisfeitos, além das anuidades em débito, as multas e demais emolumentos e taxas cabíveis.

Art. 41 - (VETADO)

Art. 42 - Nenhuma penalidade será aplicada sem que tenha sido assegurado ao infrator amplo direito de defesa.

Art. 43 - (VETADO)

Art. 44 - Não caberá ao infrator outro recurso por via administrativa.

Art. 45 - As denúncias só serão recebidas quando assinadas com a qualificação do denunciante e acompanhadas dos elementos comprobatórios do alegado, tramitando em caráter reservado, vedada a divulgação do nome do denunciante.

Art. 46 - As pessoas não habilitadas que exercerem a profissão regulamentada nesta Lei estão sujeitas às penalidades previstas na Lei de Contravenções Penais e ao pagamento de multa, a ser definida pelo Conselho Federal. 


\section{CAPITULO XI - Das Disposições Gerais e Transitórias}

Art. 47 - São equivalentes, para todos os efeitos, os diplomas de Bibliotecário, de Bacharel em Biblioteconomia e de Bacharel em Biblioteconomia e Documentação, expedidos até a data desta Lei por escolas oficialmente reconhecidas e registradas nos órgãos competentes, de acordo com a legislação em vigor.

Art. 48 - As pessoas não portadoras de diploma, que tenham exercido a atividade até 30 de janeiro de 1987, e que já estão devidamente registradas nos quadros dos Conselhos Regionais de Biblioteconomia, estão habilitadas no exercício da profissão.

Art. 49 - (VETADO)

Art. 50 - (VETADO)

Art. 51 - (VETADO)

Art. 52 - Esta Lei entra em vigor na data de sua publicação.

Art. 53 - (VETADO)

Brasília, 25 de junho de 1998; 77º da Independência e 110ํ da República.

FERNANDO HENRIQUE CARDOSO

Presidente da República

Publicada no Diário Oficial da União em 26/06/1998 - Seção I - p. 1-2. 


\section{ANEXO B: DIRETRIZES CURRICULARES PARA OS CURSOS DE BIBLIOTECONOMIA}

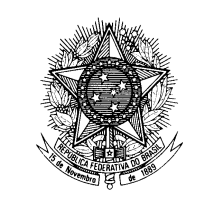

\section{MINISTÉRIO DA EDUCAÇÃO}

CONSELHO NACIONAL DE EDUCAÇÃO

\begin{tabular}{|c|c|c|c|}
\hline $\begin{array}{l}\text { INTERESSADO: Conselho Nacional } \\
\text { Educação }\end{array}$ & e Educação/C & ra Superior de & UF: DF \\
\hline $\begin{array}{l}\text { ASSUNTO: Diretrizes Curriculares } \\
\text { Geografia, Serviço Social, Comu } \\
\text { Biblioteconomia, Arquivologia e Mus }\end{array}$ & $\begin{array}{l}\text { acionais dos } \\
\text { icação Socia } \\
\text { logia }\end{array}$ & $\begin{array}{l}\text { sos de: Filoso } \\
\text { Ciências Socie }\end{array}$ & $\begin{array}{l}\text { História, } \\
\text { Letras, }\end{array}$ \\
\hline $\begin{array}{l}\text { RELATOR(ES): Eunice Ribeiro Durh } \\
\text { Figueiredo }\end{array}$ & n, Silke Weber & Vilma de Mend & \\
\hline PROCESSO(S) N.․o(S): 23001.00012 & 2001-69 & & \\
\hline PARECER N.o: CNE/CES 492/2001 & $\begin{array}{l}\text { COLEGIADO: } \\
\text { CES }\end{array}$ & $\begin{array}{l}\text { APROVADO E } \\
\text { 03/04/2001 }\end{array}$ & \\
\hline
\end{tabular}

\section{I - RELATÓRIO}

Trata o presente de diversos processos acerca das Diretrizes Curriculares Nacionais dos Cursos de Filosofia, História, Geografia, Serviço Social, Comunicação Social, Ciências Sociais, Letras, Biblioteconomia, Arquivologia e Museologia remetidas pela SESU/MEC para apreciação da CES/CNE.

A Comissão constituída pelas Conselheiras Eunice Ribeiro Durham, Vilma de Mendonça Figueiredo e Silke Weber analisou as propostas provindas da SESu referentes aos cursos mencionados e procedeu a algumas alterações com o objetivo de adequá-las ao Parecer 776/97 da Câmara de Educação Superior, respeitando, no entanto, o formato adotado pelas respectivas Comissões de Especialistas que as elaboraram. A Comissão retirou, apenas de cada uma das propostas, o item relativo à duração do curso, considerando o entendimento de que o mesmo não constitui propriamente uma diretriz e será objeto de uma Resolução específica da Câmara de Educação Superior, o que foi objeto do Parecer CNE/CES 583/2001. 


\title{
II - VOTO DO(A) RELATOR(A)
}

A Comissão recomenda a aprovação das propostas de diretrizes dos cursos mencionados na forma ora apresentada.

\author{
Brasília(DF), 03 de abril de 2001. \\ Conselheiro(a) Silke Weber - Relator(a) \\ Conselheiro(a) Eunice Ribeiro Durham \\ Conselheiro(a) Vilma de Mendonça Figueiredo
}

\section{III - DECISÃO DA CÂMARA}

A Câmara de Educação Superior aprova por unanimidade o voto do(a) Relator(a).

Sala das Sessões, em 03 de abril de 2001.

Conselheiro Arthur Roquete de Macedo - Presidente

Conselheiro Jose Carlos Almeida da Silva - Vice-Presidente 


\section{DIRETRIZES CURRICULARES PARA OS CURSOS DE BIBLIOTECONOMIA}

\section{Diretrizes Curriculares}

\section{Perfil dos Formandos}

A formação do bibliotecário supõe o desenvolvimento de determinadas competências e habilidades e o domínio dos conteúdos da Biblioteconomia. Além de preparados ara enfrentar com proficiência e criatividade os problemas de sua prática profissional, produzir e difundir conhecimentos, refletir criticamente sobre a realidade que os envolve, buscar aprimoramento contínuo e observar padrões éticos de conduta, os egressos dos referidos cursos deverão ser capazes de atuar junto a instituições e serviços que demandem intervenções de natureza e alcance variados: bibliotecas, centros de documentação ou informação, centros culturais, serviços ou redes de informação, órgãos de gestão do patrimônio cultural etc.

As IES poderão acentuar, nos projetos acadêmicos e na organização curricular, características do egresso que, sem prejuízo do patamar mínimo aqui considerado, componham perfis específicos.

\section{Competências e Habilidades}

Dentre as competências e habilidades dos graduados em Biblioteconomia enumeram-se as típicas desse nível de formação.

A) Gerais

- Gerar produtos a partir dos conhecimentos adquiridos e divulgá-los;

- Formular e executar políticas institucionais;

- Elaborar, coordenar, executar e avaliar planos, programas e projetos;

- Utilizar racionalmente os recursos disponíveis;

- Desenvolver e utilizar novas tecnologias;

- Traduzir as necessidades de indivíduos, grupos e comunidades nas respectivas áreas de atuação;

- Desenvolver atividades profissionais autônomas, de modo a orientar, dirigir, assessorar, prestar consultoria, realizar perícias e emitir laudos técnicos e pareceres;

- Responder a demandas sociais de informação produzidas pelas transformações tecnológicas que caracterizam o mundo contemporâneo.

B) Específicas 
- Interagir e agregar valor nos processos de geração, transferência e uso da informação, em todo e qualquer ambiente;

- Criticar, investigar, propor, planejar, executar e avaliar recursos e produtos de informação;

- Trabalhar com fontes de informação de qualquer natureza;

- Processar a informação registrada em diferentes tipos de suporte, mediante a aplicação de conhecimentos teóricos e práticos de coleta, processamento, armazenamento e difusão da informação;

- Realizar pesquisas relativas a produtos, processamento, transferência e uso da informação.

\section{Conteúdos Curriculares}

Os conteúdos dos cursos distribuem-se em conteúdos de formação geral, destinadas a oferecer referências cardeais externas aos campos de conhecimento próprios da Biblioteconomia e em conteúdos de formação específica, que são nucleares em relação a cada uma das identidades profissionais em pauta.

De caráter propedêutico ou não, os conteúdos de formação geral envolvem elementos teóricos e práticos e têm por objetivo o melhor aproveitamento dos conteúdos específicos de cada curso.

Os conteúdos específicos ou profissionalizantes, sem prejuízo de ênfases ou aprofundamentos programados pelas IES, têm caráter terminal. Constituem o núcleo básico no qual se inscreve a formação de bibliotecários.

O desenvolvimento de determinados conteúdos como a Metodologia da Pesquisa ou as Tecnologias em Informação, entre outras - poderá ser objeto de itens curriculares formalmente constituídos para este fim ou de atividades praticadas no âmbito de ma ou mais conteúdos.

Recomenda-se que os projetos acadêmicos acentuem a adoção de uma perspectiva humanística a formulação dos conteúdos, conferindo-lhes um sentido social e cultural que ultrapasse os aspectos utilitários mais imediatos sugeridos por determinados itens.

As IES podem adotar modalidades de parceria com outros cursos para:

- ministrar matérias comuns;

- promover ênfases específicas em determinados aspectos da carreira;

- ampliar o núcleo de formação básica;

- complementar conhecimentos auferidos em outras área. 


\section{Estágios e Atividades Complementares}

Mecanismos de interação do aluno com o mundo do trabalho em sua área, os estágios serão desenvolvidos no interior dos programas dos cursos, com intensidade variável segundo a natureza das atividades acadêmicas, sob a responsabilidade imediata de cada docente. Constituem instrumentos privilegiados para associar desempenho e conteúdo de forma sistemática e permanente.

Além disso, o colegiado do curso poderá estabelecer o desenvolvimento de atividades complementares de monitoria, pesquisa, participação em seminários e congressos, visitas programadas e outras atividades acadêmicas e culturais, igualmente orientadas por docentes (de preferência em regime de tutoria) a serem computadas como carga horária.

\section{Estrutura do Curso}

A estrutura geral do curso de Biblioteconomia deverá ser definida pelo respectivo colegiado, que indicará a modalidades de seriação, de sistema de créditos ou modular.

\section{Avaliação Institucional}

Os cursos deverão criar seus próprios critérios para a avaliação periódica, em consonância com os critérios definidos pela IES à qual pertence, incluindo aspectos técnico-científicos, didático-pedagógicos e atitudinais. 


\section{ANEXO C: HOMOLOGAÇÃO DAS DIRETRIZES CURRICULARES PARA OS CURSOS DE BIBLIOTECONOMIA}

\section{MINISTÉRIO DA EDUCAÇÃO \\ CONSELHO NACIONAL DE EDUCAÇÃO}

\begin{tabular}{|c|c|c|c|}
\hline \multicolumn{3}{|c|}{ INTERESSADO: Conselho Nacional de Educação/Câmara Superior de Educação } & UF: DF \\
\hline \multicolumn{4}{|c|}{$\begin{array}{l}\text { ASSUNTO: Diretrizes Curriculares Nacionais dos Cursos de: Filosofia, História, Geografia, Serviço } \\
\text { Social, Comunicação Social, Ciências Sociais, Letras, Biblioteconomia, Arquivologia e Museologia }\end{array}$} \\
\hline \multicolumn{4}{|c|}{ RELATOR(ES): Eunice Ribeiro Durham, Silke Weber e Vilma de Mendonça Figueiredo } \\
\hline \multicolumn{4}{|c|}{ PROCESSO(S) N.o(S): 23001.000126/2001-69 } \\
\hline PARECER N.o: CNE/CES 492/2001 & COLEGIADO: CES & APROVADO & $04 / 2001$ \\
\hline
\end{tabular}

\section{I - RELATÓRIO}

Trata o presente de diversos processos acerca das Diretrizes Curriculares Nacionais dos Cursos de Filosofia, História, Geografia, Serviço Social, Comunicação Social, Ciências Sociais, Letras, Biblioteconomia, Arquivologia e Museologia remetidas pela SESU/MEC para apreciação da CES/CNE.

A Comissão constituída pelas Conselheiras Eunice Ribeiro Durham, Vilma de Mendonça Figueiredo e Silke Weber analisou as propostas provindas da SESu referentes aos cursos mencionados e procedeu a algumas alterações com o objetivo de adequá-las ao Parecer 776/97 da Câmara de Educação Superior, respeitando, no entanto, o formato adotado pelas respectivas Comissões de Especialistas que as elaboraram. A Comissão retirou, apenas de cada uma das propostas, o item relativo à duração do curso, considerando o entendimento de que o mesmo não constitui propriamente uma diretriz e será objeto de uma Resolução específica da Câmara de Educação Superior, o que foi objeto do Parecer CNE/CES 583/2001.

\section{II - VOTO DO(A) RELATOR(A)}

A Comissão recomenda a aprovação das propostas de diretrizes dos cursos mencionados na forma ora apresentada. 
Brasília(DF), 03 de abril de 2001.

Conselheiro(a) Silke Weber - Relator(a)

Conselheiro(a) Eunice Ribeiro Durham

Conselheiro(a) Vilma de Mendonça Figueiredo

\section{III - DECISÃO DA CÂMARA}

A Câmara de Educação Superior aprova por unanimidade o voto do(a) Relator(a).

Sala das Sessões, em 03 de abril de 2001.

Conselheiro Arthur Roquete de Macedo - Presidente

Conselheiro Jose Carlos Almeida da Silva - Vice-Presidente 


\section{DIRETRIZES CURRICULARES PARA OS CURSOS DE BIBLIOTECONOMIA}

\section{Diretrizes Curriculares}

\section{Perfil dos Formandos}

A formação do bibliotecário supõe 0 desenvolvimento de determinadas competências e habilidades e o domínio dos conteúdos da Biblioteconomia. Além de preparados para enfrentar com proficiência e criatividade os problemas de sua prática profissional, produzir e difundir conhecimentos, refletir criticamente sobre a realidade que os envolve, buscar aprimoramento contínuo e observar padrões éticos de conduta, os egressos dos referidos cursos deverão ser capazes de atuar junto a instituições e serviços que demandem intervenções de natureza e alcance variados: bibliotecas, centros de documentação ou informação, centros culturais, serviços ou redes de informação, órgãos de gestão do patrimônio cultural etc.

As IES poderão acentuar, nos projetos acadêmicos e na organização curricular, características do egresso que, sem prejuízo do patamar mínimo aqui considerado, componham perfis específicos.

\section{Competências e Habilidades}

Dentre as competências e habilidades dos graduados em Biblioteconomia enumeram-se as típicas desse nível de formação.

\section{Gerais}

- Gerar produtos a partir dos conhecimentos adquiridos e divulgá-los;

- Formular e executar políticas institucionais;

- Elaborar, coordenar, executar e avaliar planos, programas e projetos;

- Utilizar racionalmente os recursos disponíveis;

- Desenvolver e utilizar novas tecnologias;

- Traduzir as necessidades de indivíduos, grupos e comunidades nas respectivas áreas de atuação;

- Desenvolver atividades profissionais autônomas, de modo a orientar, dirigir, assessorar, prestar consultoria, realizar perícias e emitir laudos técnicos e pareceres;

- Responder a demandas sociais de informação produzidas pelas transformações tecnológicas que caracterizam o mundo contemporâneo.

\section{Específicas}

- Interagir e agregar valor nos processos de geração, transferência e uso da informação, em todo e qualquer ambiente;

- Criticar, investigar, propor, planejar, executar e avaliar recursos e produtos de informação;

- Trabalhar com fontes de informação de qualquer natureza; 
- Processar a informação registrada em diferentes tipos de suporte, mediante a aplicação de conhecimentos teóricos e práticos de coleta, processamento, armazenamento e difusão da informação;

- Realizar pesquisas relativas a produtos, processamento, transferência e uso da informação.

\section{Conteúdos Curriculares}

Os conteúdos dos cursos distribuem-se em conteúdos de formação geral, destinadas a oferecer referências cardeais externas aos campos de conhecimento próprios da Biblioteconomia e em conteúdos de formação específica, que são nucleares em relação a cada uma das identidades profissionais em pauta.

\section{a) Conteúdos de Formação Geral}

De caráter propedêutico ou não, os conteúdos de formação geral envolvem elementos teóricos e práticos e têm por objetivo o melhor aproveitamento dos conteúdos específicos de cada curso.

\section{b) Conteúdos de Formação Específica}

Os conteúdos específicos ou profissionalizantes, sem prejuízo de ênfases ou aprofundamentos programados pelas IES, têm caráter terminal. Constituem o núcleo básico no qual se inscreve a formação de bibliotecários.

O desenvolvimento de determinados conteúdos como a Metodologia da Pesquisa ou as Tecnologias em Informação, entre outras - poderá ser objeto de itens curriculares formalmente constituídos para este fim ou de atividades praticadas no âmbito de uma ou mais conteúdos.

Recomenda-se que os projetos acadêmicos acentuem a adoção de uma perspectiva humanística a formulação dos conteúdos, conferindo-lhes um sentido social e cultural que ultrapasse os aspectos utilitários mais imediatos sugeridos por determinados itens.

As IES podem adotar modalidades de parceria com outros cursos para:

a) ministrar matérias comuns;

b) promover ênfases específicas em determinados aspectos da carreira;

c) ampliar o núcleo de formação básica;

d) complementar conhecimentos auferidos em outras área.

\section{Estágios e Atividades Complementares}

Mecanismos de interação do aluno com o mundo do trabalho em sua área, os estágios serão desenvolvidos no interior dos programas dos cursos, com intensidade variável segundo a natureza das atividades acadêmicas, sob a responsabilidade 
imediata de cada docente. Constituem instrumentos privilegiados para associar desempenho e conteúdo de forma sistemática e permanente.

Além disso, o colegiado do curso poderá estabelecer o desenvolvimento de atividades complementares de monitoria, pesquisa, participação em seminários e congressos, visitas programadas e outras atividades acadêmicas e culturais, igualmente orientadas por docentes (de preferência em regime de tutoria) a serem computadas como carga horária.

\section{Estrutura do Curso}

A estrutura geral do curso de Biblioteconomia deverá ser definida pelo respectivo colegiado, que indicará a modalidades de seriação, de sistema de créditos ou modular.

\section{Avaliação Institucional}

Os cursos deverão criar seus próprios critérios para a avaliação periódica, em consonância com os critérios definidos pela IES à qual pertence, incluindo aspectos técnico-científicos, didático-pedagógicos e atitudinais.

\section{GABINETE DO MINISTRO DESPACHOS DO MINISTRO Em 4 de julho de 2001}

Nos termos do art. $2^{\circ}$ da Lei no 9.131, de 24 de novembro de 1995, o Ministro de Estado da Educação HOMOLOGA o Parecer no 492/2001, da Câmara de Educação Superior do Conselho Nacional de Educação, favorável à aprovação das propostas de Diretrizes Curriculares Nacionais dos cursos de Filosofia, História, Geografia, Serviço Social, Comunicação Social, Ciências Sociais, Letras, Biblioteconomia, Arquivologia e Museologia, conforme consta do Processo n²3001.000126/2001-69. 


\section{IFLA/UNESCO}

Public Library Manifesto

\section{4}

\section{MANIFESTO DA IFLA/UNESCO SOBRE BIBLIOTECAS PÚBLICAS \\ 1994}

\section{[Portuguese Version]}

A liberdade, a prosperidade e o desenvolvimento da sociedade e dos indivíduos são valores humanos fundamentais. Só serão atingidos quando os cidadãos estiverem na posse da informação que lhes permita exercer os seus direitos democráticos e ter um papel activo na sociedade. A participação construtiva e o desenvolvimento da democracia dependem tanto de uma educação satisfatória, como de um acesso livre e sem limites ao conhecimento, ao pensamento, à cultura e à informação.

A biblioteca pública - porta de acesso local ao conhecimento - fornece as condições básicas para uma aprendizagem contínua, para uma tomada de decisão independente e para o desenvolvimento cultural dos indivíduos e dos grupos sociais.

Este Manifesto proclama a confiança que a UNESCO deposita na Biblioteca Pública, enquanto força viva para a educação, a cultura e a informação, e como agente essencial para a promoção da paz e do bem-estar espiritual nas mentes dos homens e das mulheres.

Assim, a UNESCO encoraja as autoridades nacionais e locais a apoiar activamente e a comprometerem-se no desenvolvimento das bibliotecas públicas.

\section{A Biblioteca Pública}

A biblioteca pública é o centro local de informação, tornando prontamente acessíveis aos seus utilizadores o conhecimento e a informação de todos os géneros.

Os serviços da biblioteca pública devem ser oferecidos com base na igualdade de acesso para todos, sem distinção de idade, raça, sexo, religião, nacionalidade, língua ou condição social. Serviços e materiais específicos devem ser postos à disposição dos utilizadores que, por qualquer razão, não possam usar os serviços e os materiais correntes, como por exemplo minorias linguísticas, pessoas deficientes, hospitalizadas ou reclusas.

Todos os grupos etários devem encontrar documentos adequados às suas necessidades. As colecções e serviços devem incluir todos os tipos de suporte e tecnologias modernas apropriados assim como fundos tradicionais. É essencial que sejam de elevada qualidade e adequadas às necessidades e condições locais. As colecções devem reflectir as tendências actuais e a evolução da sociedade, bem como a memória da humanidade e o produto da sua imaginação. 
As colecções e os serviços devem ser isentos de qualquer forma de censura ideológica, política ou religiosa e de pressões comerciais.

\section{Missões da Biblioteca Pública}

As missões-chave da biblioteca pública relacionadas com a informação, a alfabetização, a educação e a cultura são as seguintes:

Criar e fortalecer os hábitos de leitura nas crianças, desde a primeira infância;

Apoiar a educação individual e a auto-formação, assim como a educação formal a todos os níveis;

Assegurar a cada pessoa os meios para evoluir de forma criativa;

Estimular a imaginação e criatividade das crianças e dos jovens;

Promover o conhecimento sobre a herança cultural, o apreço pelas artes e pelas realizações e inovações científicas;

Possibilitar o acesso a todas as formas de expressão cultural das artes do espectáculo; Fomentar o diálogo inter-cultural e a diversidade cultural;

Apoiar a tradição oral;

Assegurar o acesso dos cidadãos a todos os tipos de informação da comunidade local; Proporcionar serviços de informação adequados às empresas locais, associações e grupos de interesse;

Facilitar o desenvolvimento da capacidade de utilizar a informação e a informática; Apoiar, participar e, se necessário, criar programas e actividades de alfabetização para os diferentes grupos etários.

\section{Financiamento, legislação e redes}

- Os serviços da biblioteca pública devem, em princípio, ser gratuitos. A biblioteca pública é da responsabilidade das autoridades locais e nacionais. Deve ser objecto de uma legislação específica e financiada pelos governos nacionais e locais. Tem de ser uma componente essencial de qualquer estratégia a longo prazo para a cultura, $o$ acesso à informação, a alfabetização e a educação.

- Para assegurar a coordenação e cooperação das bibliotecas, a legislação e os planos estratégicos devem ainda definir e promover uma rede nacional de bibliotecas, baseada em padrões de serviço previamente acordados.

- A rede de bibliotecas públicas deve ser concebida tendo em consideração as bibliotecas nacionais, regionais, de investigação e especializadas, assim como com as bibliotecas escolares e universitárias.

\section{Funcionamento e gestão}

- Deve ser formulada uma política clara, definindo objectivos, prioridades e serviços, relacionados com as necessidades da comunidade local. A biblioteca pública deve ser eficazmente organizada e mantidos padrões profissionais de funcionamento.

- Deve ser assegurada a cooperação com parceiros relevantes, por exemplo, grupos de utilizadores e outros profissionais a nível local, regional, nacional e internacional.

- Os serviços têm de ser fisicamente acessíveis a todos os membros da comunidade. Tal supõe a existência de edifícios bem situados, boas condições para a leitura e o estudo, assim como o acesso a tecnologia adequada e horários convenientes para os utilizadores. Tal implica igualmente serviços destinados àqueles a quem é impossível frequentar a biblioteca. 
- Os serviços da biblioteca devem ser adaptados às diferentes necessidades das comunidades das zonas urbanas e rurais.

- O bibliotecário é um intermediário activo entre os utilizadores e os recursos disponíveis. A formação profissional contínua do bibliotecário é indispensável para assegurar serviços adequados.

- Têm de ser levados a cabo programas de formação de potenciais utilizadores de forma a fazê-los beneficiar de todos os recursos.

\section{Implementação do Manifesto}

Todos os que em todo o mundo, a nível nacional e local, têm poder de decisão e a comunidade de bibliotecários em geral são instados a implementar os princípios expressos neste Manifesto.

O Manifesto foi preparado em cooperação com a IFLA. 


\section{ANEXO E: MANIFESTO IFLA/UNESCO PARA BIBLIOTECA ESCOLAR}

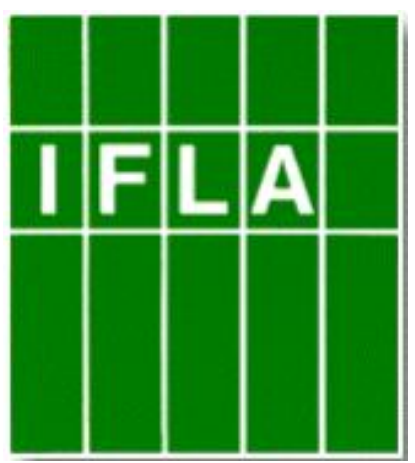

\section{MANIFESTO IFLA/UNESCO PARA BIBLIOTECA ESCOLAR}

Edição em língua portuguesa - Brasil, São Paulo ${ }^{15} 1617$

\section{A BIBLIOTECA ESCOLAR NO ENSINO E APRENDIZAGEM PARA TODOS}

A biblioteca escolar (BE) propicia informação e idéias fundamentais para seu funcionamento bem sucedido na atual sociedade, baseada na informação e no conhecimento. A BE habilita os estudantes para a aprendizagem ao longo da vida e desenvolve a imaginação, preparando-os para viver como cidadãos responsáveis.

\section{A MISSÃO DA BIBLIOTECA ESCOLAR}

A biblioteca escolar promove serviços de apoio à aprendizagem e livros aos membros da comunidade escolar, oferecendo-lhes a possibilidade de se tornarem pensadores críticos e efetivos usuários da informação, em todos os formatos e meios. As bibliotecas escolares ligam-se às mais extensas redes de bibliotecas e de informação, em observância aos princípios do Manifesto UNESCO para Biblioteca Pública.

O quadro de pessoal da biblioteca constitui-se em suporte ao uso de livros e outras fontes de informação, desde obras de ficção até outros tipos de documentos, tanto impressos como eletrônicos, destinados à consulta presencial ou remota. Este acervo se complementa e se enriquece com manuais, obras didáticas e metodológicas.

\footnotetext{
15 A tradução feita para o Brasil, São Paulo, é de autoria da Profa. Dra. Neusa Dias de Macedo [nedima@ig.com.br], que é MSLS pela Catholic University of America, Washington, DC; bacharel, licenciada e doutora em Letras pela Faculdade de Filosofia, Ciências e Letras da Universidade de São Paulo; docente aposentada do Departamento de Biblioteconomia e Documentação, Escola de Comunicação e Artes da USP e assessora especial ao Projeto Biblioteca Escolar/FEBAB. Ver também UNESCO/IFLA Diretrizes para Bibliotecas Escolares, 2002.

${ }^{16}$ O Manifesto foi preparado pela IFLA e aprovado pela UNESCO em sua Conferência Geral de novembro de 1999. Existe tradução para o português de Portugal.

${ }^{17}$ Original inglês obtido em http://www.ifla.org (rev. de 16 de fevereiro de 2000).
} 
Está comprovado que bibliotecários e professores, ao trabalharem em conjunto, influenciam o desempenho dos estudantes para o alcance de maior nível de literacia na leitura e escrita, aprendizagem, resolução de problemas, uso da informação e das tecnologias de comunicação e informação.

Os serviços das bibliotecas escolares devem ser oferecidos igualmente a todos os membros da comunidade escolar, a despeito de idade, raça, sexo, religião, nacionalidade, língua e status profissional e social. Serviços e materiais específicos devem ser disponibilizados a pessoas não aptas ao uso dos materiais comuns da biblioteca.

O acesso às coleções e aos serviços deve orientar-se nos preceitos da Declaração Universal de Direitos e Liberdade do Homem, das Nações Unidas, e não deve estar sujeito a qualquer forma de censura ideológica, política, religiosa, ou a pressões comerciais.

\section{FINANCIAMENTO, LEGISLAÇÃO E REDES}

A biblioteca escolar é essencial a qualquer tipo de estratégia de longo prazo no que respeita a competências à leitura e escrita, à educação e informação e ao desenvolvimento econômico, social e cultural. A responsabilidade sobre a biblioteca escolar cabe às autoridades locais, regionais e nacionais, portanto deve essa agência ser apoiada por política e legislação específicas. Deve também contar com fundos apropriados e substanciais para pessoal treinado, materiais, tecnologias e instalações. A BE deve ser gratuita.

A biblioteca escolar é parceiro imprescindível para atuação em redes de biblioteca e informação tanto em nível local, regional como nacional.

Os objetivos próprios da biblioteca escolar devem ser devidamente reconhecidos e mantidos sempre que ela estiver compartilhando instalações e recursos com outros tipos de biblioteca, em particular com a biblioteca pública.

\section{OBJETIVOS DA BIBLIOTECA ESCOLAR}

A biblioteca escolar é parte integral do processo educativo.

Para o desenvolvimento da literacia e/ou competência na leitura e escrita e no uso da informação, no ensino e aprendizagem, na cultura e nos serviços básicos da biblioteca escolar, é essencial o cumprimento dos seguintes objetivos:

- apoiar e intensificar a consecução dos objetivos educacionais definidos na missão e no currículo da escola;

- desenvolver e manter nas crianças o hábito e o prazer da leitura e da aprendizagem, bem como o uso dos recursos da biblioteca ao longo da vida;

- oferecer oportunidades de vivências destinadas à produção e uso da informação voltada ao conhecimento, à compreensão, imaginação e ao entretenimento;

- apoiar todos os estudantes na aprendizagem e prática de habilidades para avaliar e usar a informação, em suas variadas formas, suportes ou meios, incluindo a sensibilidade 
para 3 utilizar adequadamente as formas de comunicação com a comunidade onde estão inseridos;

- prover acesso em nível local, regional, nacional e global aos recursos existentes e às oportunidades que expõem os aprendizes a diversas idéias, experiências e opiniões; organizar atividades que incentivem a tomada de consciência cultural e social, bem como de sensibilidade;

- trabalhar em conjunto com estudantes, professores, administradores e pais, para o alcance final da missão e objetivos da escola; proclamar o conceito de que a liberdade intelectual e o acesso à informação são pontos fundamentais à formação de cidadania responsável e ao exercício da democracia;

- promover leitura, recursos e serviços da biblioteca escolar junto à comunidade escolar e ao seu derredor.

À biblioteca escolar cumpre exercer todas essas funções, por meio de políticas e serviços; seleção e aquisição de recursos; provimento do acesso físico e intelectual a fontes adequadas de informação; fornecimento de instalações voltadas à instrução; contratação de pessoal treinado.

\section{PESSOAL}

O bibliotecário escolar é o membro profissionalmente qualificado, responsável pelo planejamento e gestão da biblioteca escolar. Deve ser apoiado tanto quanto possível por equipe adequada, trabalha em conjunto com todos os membros da comunidade escolar e deve estar em sintonia com bibliotecas públicas e outros.

O papel do bibliotecário escolar varia de acordo com orçamentos, currículos e metodologias de ensino das escolas, dentro do quadro legal e financeiro do país. Em contextos específicos, há áreas gerais de conhecimento que são vitais se os bibliotecários escolares assumirem o desenvolvimento e a operacionalização de serviços efetivos: gestão da biblioteca, dos recursos, da informação e ensino.

Em vista do crescimento dos ambientes de rede, os bibliotecários escolares devem tornar-se competentes no planejamento e na instrução das diferentes habilidades para o manuseio de novas ferramentas de informação, tanto a professores como a estudantes. Portanto, devem obter contínuo treinamento e desenvolvimento profissional.

\section{SERVIÇOS E GESTÃO}

Para assegurar serviços efetivos e responsáveis:

- formular política própria para os serviços de biblioteca, definindo objetivos, prioridades e serviços de acordo com o currículo da escola;

- aplicar padrões profissionais na organização e manutenção da biblioteca escolar;

- prover acesso a serviços e à informação a todos os membros da comunidade escolar, e funcionar dentro do contexto da comunidade local. 
- incentivar a cooperação entre professores, gestores experientes na área escolar, administradores, pais, outros bibliotecários e profissionais da informação e grupos interessados da comunidade.

\section{APLICAÇÃO DO MANIFESTO}

Por intermédio de ministérios da educação e cultura, são conclamados os governantes de cada país para desenvolver estratégias, políticas e planos de implementação aos princípios deste Manifesto.

Esses planos devem prever intensa divulgação do Manifesto, tanto em programas de formação básica como de educação contínua a bibliotecários e professores.

$$
* * *
$$

IFLA/UNESCO School Library Manifesto: http://www.ifla.org/VII/s11/pubs/schoolmanif.htm 


\section{ANEXO F: MANIFESTO IFLA/UNESCO POR LA BIBLIOTECA MULTICULTURAL}

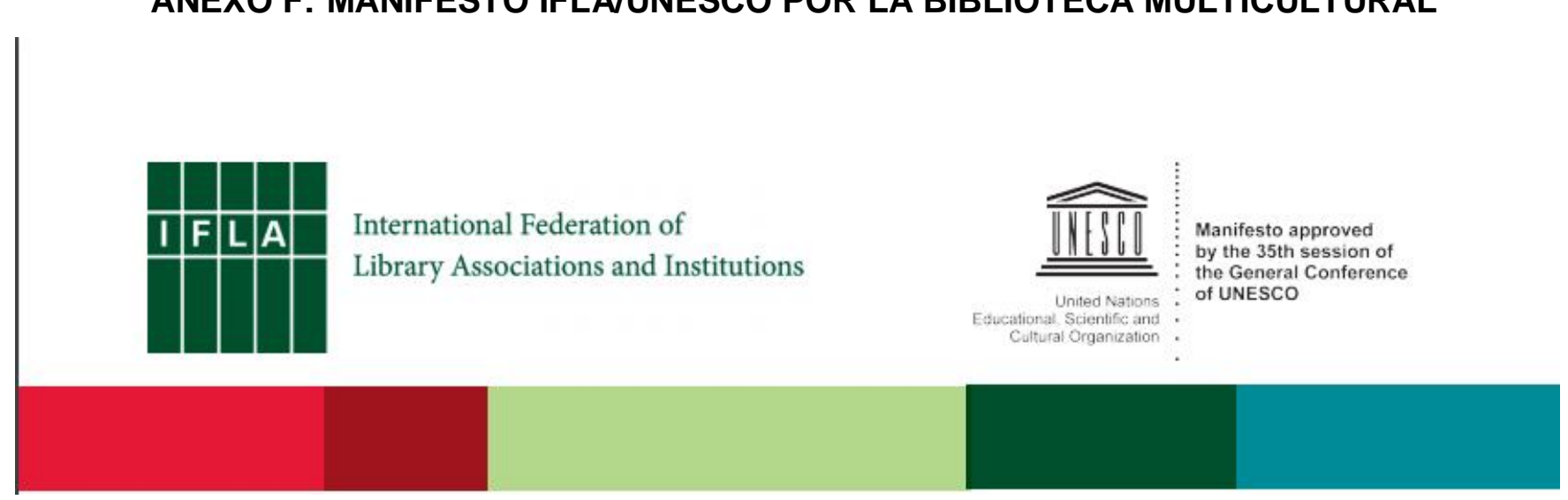

Manifiesto IFLA/UNESCO por la Biblioteca multicultural

\section{La biblioteca multicultural: portal de acceso a una sociedad de culturas diversas en diálogo}

Todos vivimos en una sociedad que es cada vez más heterogénea. Existen más de 6000 lenguas en el mundo. La tasa de migración internacional se incrementa cada año, lo que origina un número creciente de personas con identidades más complejas. La globalización, el aumento de las migraciones, la rapidez de las comunicaciones, la facilidad del transporte y otros factores característicos del siglo XXI han incrementado la diversidad cultural en muchas naciones donde previamente no existía o han umentado la ya existente.

La «diversidad cultural»o «multiculturalidad» se refieren a la coexistencia e interacción armónica de culturas diferentes, donde «la cultura debe ser considerada como el conjunto de los rasgos distintivos espirituales y materiales, intelectuales y afectivos que caracterizan a una sociedad o a un grupo social y que abarca, además de las artes y las letras, los modos de vida, las maneras de vivir juntos, los sistemas de valores, las tradiciones y las creencias»1 . La diversidad cultural o la multiculturalidad son la base de nuestra fuerza colectiva, tanto en nuestras comunidades locales como en nuestra ociedad global.

La diversidad cultural y lingüística es el patrimonio común de la humanidad y debe ser conservada y mantenida para el beneficio de todos. Es una fuente de intercambio, innovación, creatividad, y coexistencia pacífica entre los pueblos. «El respeto de la diversidad de las culturas, la tolerancia, el diálogo y la cooperación, en un clima de confianza y de entendimiento mutuos, están entre los mejores garantes de la paz y la seguridad internacionales» 2 . Por tanto, todos los tipos de bibliotecas deben reflejar, apoyar y promover la diversidad cultural y lingüística en los ámbitos locales, nacionales e internacionales, y de esta manera trabajar por el diálogo intercultural y una ciudadanía activa.

Las bibliotecas, al servir a intereses y comunidades diversas, funcionan como centros de aprendizaje, culturales y de información. Al tratar la diversidad cultural y lingüística, los 
servicios bibliotecarios se rigen por su compromiso con los principios de las libertades fundamentales y la igualdad en el acceso a la información y al conocimiento para todos, en el respeto de la identidad y los valores culturales.

\section{Principios}

Cada persona de nuestra sociedad global tiene derecho a un amplio rango de servicios bibliotecarios y de información. Al tratar la diversidad lingüística y cultural, las bibliotecas deberían:

- Servir a todos lo miembros de la comunidad sin discriminación alguna por origen cultural o lingüístico;

- Ofrecer información en las lenguas y alfabetos pertinentes;

- Dar acceso a un amplio rango de materiales y servicios que reflejen a todas las comunidades y sus necesidades;

- Disponer de personal que refleje la diversidad de la comunidad, formados para trabajar y dar servicio a comunidades diversas.

Los servicios bibliotecarios y de información en un contexto de diversidad cultural y linguística incluyen tanto la oferta de servicios a todo tipo de usuarios de la biblioteca como la oferta de servicios bibliotecarios dirigidos especialmente a grupos culturales y lingüísticos tradicionalmente más desatendidos. Se debería prestar especial atención a grupos que a menudo sufren marginación en las sociedades con diversidad cultural: minorías, refugiados y solicitantes de asilo, personas con permisos de residencia temporales, trabajadores inmigrantes y comunidades indígenas.

\section{Misión de los servicios bibliotecarios multiculturales}

En una sociedad culturalmente diversa se debería incidir en las siguientes misiones clave, relacionadas con la información, la alfabetización, la educación y la cultura:

- Fomentar la toma de conciencia del valor positivo de la diversidad cultural y promover el diálogo cultural;

- Alentar la diversidad lingüística y el respeto por las lenguas maternas;

- Facilitar la coexistencia armónica de varias lenguas, incluyendo el aprendizaje de varias lenguas desde edades tempranas;

- Salvaguardar el patrimonio cultural y lingüístico y apoyar la expresión, creación y difusión en todas las lenguas pertinentes;

- Apoyar la preservación de la tradición oral y el patrimonio cultural intangible;

- Apoyar la inclusión y participación de personas y grupos de diversos orígenes culturales;

- Promover la alfabetización informacional en la era digital, y el dominio de las tecnologías de la información y comunicación;

- Promover la diversidad lingüística en el ciberespacio;

- Fomentar el acceso universal al ciberespacio; 
- Apoyar el intercambio de conocimientos y buenas prácticas en relación con el pluralismo cultural.

\section{Gestión y actuación}

La biblioteca multicultural requiere que todas las bibliotecas adopten un enfoque integrado de los servicios. Las actividades principales de los servicios bibliotecarios y de información para comunidades cultural y lingüísticamente diversas son centrales, no «separadas» ni «adicionales», y siempre deberían estar diseñadas para satisfacer necesidades locales o específicas.

La biblioteca debería tener una política y un plan estratégico, que definan su misión, objetivos, prioridades y servicios relacionados con la diversidad cultural. El plan debe basarse en un análisis completo de las necesidades de los usuarios y en recursos adecuados.

Las actividades bibliotecarias no deben llevarse a cabo aisladamente. Se debe fomentar la cooperación con los grupos de usuarios y profesionales pertinentes en el ámbito local, nacional e internacional.

\section{Actividades principales}

La biblioteca multicultural debería:

- Desarrollar colecciones y servicios culturalmente diversos y multilingües, incluyendo recursos digitales y multimedia;

- Destinar recursos para la conservación de las expresiones y el patrimonio cultural, prestando especial atención al patrimonio cultural oral, indígena e intangible;

- Incluir programas que apoyen la educación de los usuarios, la alfabetización informacional, los recursos para los recién llegados, el patrimonio cultural y el diálogo intercultural como partes integrales de los servicios

- Proporcionar acceso a los recursos bibliotecarios en los idiomas pertinentes a través de sistemas de acceso y organización de la información;

- Desarrollar materiales de promoción y difusión en las lenguas apropiadas para atraer a diversos grupos a la biblioteca.

\section{Personal}

El personal de la biblioteca es el intermediario activo entre usuarios y recursos. Se le debe ofertar educación profesional y formación continua centrada en los servicios a comunidades multiculturales, la comunicación y la sensibilidad intercultural, la antidiscriminación, las culturas y las lenguas.

El personal de una biblioteca multicultural debería reflejar las características lingüísticas y culturales de la comunidad para garantizar la conciencia cultural, reflejar la comunidad a la que la biblioteca presta servicio y promover la comunicación.

\section{La financiación, la legislación y redes}


Se insta a los gobiernos y a otros organismos pertinentes de toma de decisiones a establecer y financiar adecuadamente bibliotecas y sistemas bibliotecarios para que ofrezcan servicios bibliotecarios y de información gratuitos a comunidades culturalmente diversas.

Los servicios bibliotecarios multiculturales son esencialmente globales. Todas las bibliotecas implicadas en actividades de este campo deben participar en las redes pertinentes de desarrollo de políticas locales, nacionales e internacionales. Se necesita investigación para obtener los datos necesarios para tomar decisiones informadas sobre los servicios y asegurar una financiación apropiada. Se deben difundir ampliamente los resultados de estas investigaciones y las buenas prácticas para impulsar servicios bibliotecarios multiculturales eficaces.

\section{Implementar el Manifiesto}

La comunidad internacional debe reconocer y apoyar los servicios bibliotecarios y de información en su papel de promotores y conservadores de la diversidad lingüística y cultural.

Se solicita a los responsables de todos los niveles y a la comunidad bibliotecaria de todo el mundo que difundan este Manifiesto y que lleven a cabo los principios y acciones que aquí se expresan.

Este Manifiesto complementa al Manifiesto de la IFLA/UNESCO sobre la biblioteca pública, al Manifiesto la biblioteca escolar (IFLA/UNESCO) y al Manifiesto sobre Internet de la IFLA.

El Comité ejecutivo de IFLA aprobó este Manifiesto en agosto de 2006 y El Consejo Intergubernamental del Programa Información para todos (IFAP) de UNESCO lo aprobó en abril de 2008 con la recomendación de que sea presentado para su consideración en la $35^{\text {a }}$ sesión de la Conferencia General de UNESCO. 


\section{ANEXO G: CURRÍCULOS E PROPOSTAS CURRICULARES DE BIBLIOTECONOMIA NO BRASIL (1911-1982) ${ }^{18}$}

Currículos e Propostas Curriculares de Biblioteconomia no Brasil: 1911-1982 - Parte 1

\begin{tabular}{|c|c|c|c|c|c|c|c|c|}
\hline \multicolumn{4}{|c|}{ Bibloteca Nacional } & \multirow{2}{*}{$\begin{array}{c}\text { Mackenzia } \\
1938\end{array}$} & \multirow{2}{*}{\begin{tabular}{|c|}
$\begin{array}{c}\text { Depto. de Culura } \\
\text { (Sto Paub) }\end{array}$ \\
1949 \\
(2 anos)
\end{tabular}} & \multicolumn{3}{|c|}{ ELSP } \\
\hline $\begin{array}{c}1915 \\
\text { (1 ano) }\end{array}$ & $\begin{array}{c}1931 \\
\text { (2 anos) }\end{array}$ & 1944 & 1962 & & & $1936-1937$ & $\begin{array}{c}1940 \\
\text { (2 anos) }\end{array}$ & 1944 \\
\hline $\begin{array}{l}\text { Biblografia } \\
\text { Paleografia } \\
\text { Diplomájca } \\
\text { Numismatica }\end{array}$ & $\begin{array}{l}\text { Historia } \\
\text { Literaria com } \\
\text { Aplicaçao a } \\
\text { Biblografia } \\
\text { Iconografia e } \\
\text { Cartografia } \\
\text { Biblografia } \\
\\
\text { Paleografia } \\
\text { Diplomasica }\end{array}$ & 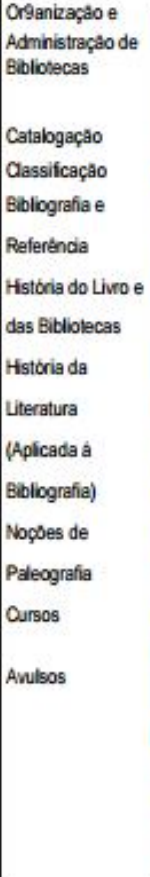 & 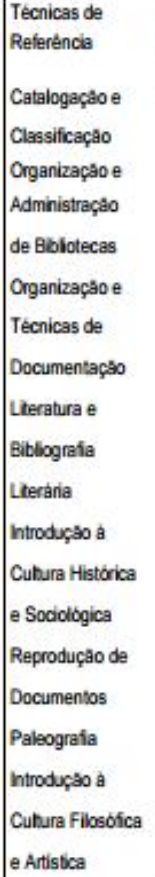 & $\begin{array}{l}\text { Catabgaçào } \\
\text { Classificaçao } \\
\text { Referéncia }\end{array}$ & $\begin{array}{l}\text { Cataloggaçao } \\
\text { Classificaç̧a } \\
\text { Relerencia }\end{array}$ & $\begin{array}{l}\text { Catalogaçáo } \\
\text { Classificaçao } \\
\text { Referencia } \\
\text { Histónia do Limo e } \\
\text { das Biblotecas }\end{array}$ & $\begin{array}{l}\text { Classificaça } \\
\text { Referencia } \\
\text { Historia do Livro } \\
\text { e das Bibliotecas } \\
\text { Referencia }\end{array}$ & 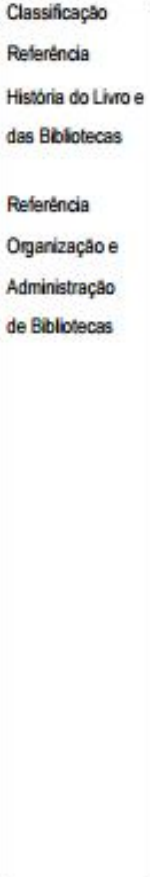 \\
\hline
\end{tabular}

${ }^{18}$ CASTRO (2000). 
Currículos e Propostas Curriculares de Biblioteconomia no Brasil:

1911-1982 - Parte 2



